$$
\frac{\text { E S T U D I O S }}{\text { FILOSOFÍA HISTORIA • LETRAS }}
$$


CITAM Derechos Reservados.

La reproducción total o parcial de este artículo se podrá hacer si el ITAM otorga la autorización previamente por escrito. 


\section{E S T U D I O S FILOSOFÍA • HISTORIA • LETRAS}

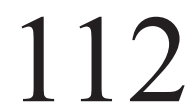

PRIMAVERA 2015

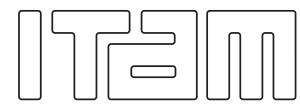

DEPARTAMENTO ACADÉMICO DE ESTUDIOS GENERALES 
ESTUDIOS • filosofía $\bullet$ historia $\bullet$ letras recoge artículos de investigación, notas académicas y reseñas críticas en torno a las humanidades. Aparece trimestralmente en primavera, verano, otoño e invierno. ESTUDIOS está incluída en los siguientes índices:

- Latindex: Sistema Regional de Información en Línea para Revistas Científicas de América Latina, el Caribe, España y Portugal.

- EBSCO.

- in4mex.

Precio por número: \$ 50.00 M.N. Extranjero 10 dls. (incluye gastos de envío) Suscripción anual (4 números): \$ 180.00 M.N. en la República Mexicana

35 dls. en el extranjero (incluye gastos de envío)

Suscripción bianual (8 números): \$ 350.00 M.N. en la República Mexicana 65 dls. en el extranjero (incluye gastos de envío)

\section{Correspondencia:}

Instituto Tecnológico Autónomo de México

Departamento Académico de Estudios Generales

Río Hondo No. 1,

Col. Progreso Tizapán

01080, México, D.F.

Tels.: 56284000 exts. 3900 y 3903

e-mail: estudios@itam.mx

www.estudios.itam.mx

ISSN 0185-6383

Licitud de título No. 9999

Licitud de contenido No. 6993

Derechos de autor: 003161/96

Se agradece el apoyo de la Asociación Mexicana de Cultura, A.C.

Diseño portada: Nohemí Sánchez

Diseño Editorial: Yanet Viridiana Morales García (ITAM)

Distribución: Carmen Graciela Roldán (ITAM)

Impresión y encuadernación: Alfonso Sandoval Mazariego, Tizapán 172, Col. Metropolitana 3a. sección, C.P.57750, Ciudad Nezahualcóyotl,EstadodeMéxico, Tel.:(+5255)57934152/57937224. Se prohibe su reproducción total o parcial por cualquier medio, incluido electrónico, sin permiso previo y por escrito de los editores. 


\section{ÍNDICE}

\section{TEXTOS}

SOBRE LOS MODOS DE REPRESENTACIÓN EN WALTER BENJAMIN

Carlos Alfonso Garduño

SOBRE LA FENOMENOLOGÍA DE LA HISTORIA EN EDMUND HUSSERL María Dolores Illescas

LA ESCALERA DE WITTGENSTEIN Javier García-Salcedo

SECCIÓN ESPECIAL

LA ÉPICA GRIEGA ARCAICA (CUÉNTAME ALGO DE HOMERO) Pedro C. Tapia Zúñiga

\section{DIÁLOGO DE POETAS}

\section{CREACIÓN}

Jonathan García Palma 


\section{NOTAS}

LA ENCRUCIJADA DE LA DOBLE MEMORIA EN PLOTINO José Molina Ayala

LA LIGA IROQUESA Y LA CONSTITUCIÓN ESTADOUNIDENSE María Julia Sierra

EL IMPACTO DE LAS NUEVAS TECNOLOGÍAS EN LAS PERSPECTIVAS DEL PAISAJE

\section{RESEÑAS}

PATRICIA FUNES, Historia mínima de las ideas políticas en América Latina, Joseph Hodara

CARlo NATALI, Aristotle, Valeria López Vela

JOHN BAILEY, Crimen e impunidad. Las trampas de la inseguridad en México, José Manuel Orozco Garibay 


\section{SOBRE LOS MODOS DE REPRESENTACIÓN EN WALTER BENJAMIN \\ Carlos Alfonso Garduño*}

RESUMEN: A partir del Programa de la filosofia venidera propuesto por Benjamin, en el que enfatiza la necesidad de desarrollar la metafísica y la teología que posibilitan la fundamentación trascendental kantiana, en este texto se exploran algunos de los modos de representación que en la obra de Benjamin nos permiten concebir el horizonte de experiencia que dicha filosofía abriría ante nosotros.

$$
\text { গ০e }
$$

\section{WALTER BENJAMIN'S WAYS OF REPRESENTATION}

ABSTRACT: From Benjamin's Program of the coming philosophy, emphasizing the need for the development of metaphysics and theology allowing for Kantian transcendental foundations, we will explore in this text how Benjamin's ways of representation in his works allow us to appreciate the experience which his philosophy lays before us.

PALABRAS CLAVE: lenguaje, representación, novela, tragedia, traducción, esperanza. KEY WORDS: language, representation, novel, tragedy, translation, hope.

RECEPCIÓN: 22 de agosto de 2013.

APROBACIÓN: 12 de marzo de 2014.

* Investigador posdoctoral, École des Haustes Études en Sciences Sociales, París. 
CITAM Derechos Reservados.

La reproducción total o parcial de este artículo se podrá hacer si el ITAM otorga la autorización previamente por escrito. 


\section{SOBRE LOS MODOS \\ DE REPRESENTACIÓN EN WALTER BENJAMIN}

$\mathrm{E}_{\mathrm{n} \text { su texto Sobre el programa de la }}$ filosofía venidera, Walter Benjamin apunta que la filosofía de nuestro tiempo no debe evadir la subjetividad trascendental postulada por Kant, sino formular las exigencias que impone "en el cuadro de la tipología kantiana, de fundar en términos de teoría de conocimiento un concepto superior de experiencia". ${ }^{1}$ De lo que se trata es de señalar el espacio de la posible experiencia superior, en términos de los principios a priori de nuestras facultades de conocimiento. Con ello, la cuestión es la siguiente: ¿Qué nos puede llevar en Kant a una experiencia superior? La crítica trascendental permite establecer los criterios para diferenciar el valor de los distintos tipos de conciencia y, en función de ello, sienta las bases de la posible unidad de la experiencia, la cual, por la crítica realizada, no será ni vulgar, ni científica, sino ambas; es decir, será metafísica: "Este nuevo concepto de experiencia que será fundado sobre las nuevas condiciones de conocimiento, constituirá él mismo el lugar lógico y la posibilidad lógica de la metafísica". ${ }^{2}$ Una metafísica, pues, que ligue la experiencia a Dios, sin recaer en el mito y el dogmatismo, pero que a su vez nos permita trasformar el concepto de libertad formal, vacío y de consecuencias inhibidoras, en uno que enriquezca la experiencia resolviendo

${ }^{1}$ Walter Benjamin, "Sur le programme de la philosophie qui vient", en Euvres, 2000, Paris, Gallimard, vol. I, p. 182 (todas las citas de los originales en francés e inglés son traducciones mías).

${ }^{2}$ Ibid., p. 187. 
su oposición al conocimiento y la técnica. Así, Benjamin intenta mostrar el camino hacia una posible metafísica moderna, e incluso hacia una teología. Pero, ¿cómo concebirlo después de la crítica kantiana?

Más que una síntesis totalizadora de la experiencia, lo que Benjamin tiene en mente es que "una cierta no-síntesis de dos conceptos en un tercero tomará la más alta importancia sistemática, porque otro distinto a la síntesis es posible entre la tesis y la antítesis". ${ }^{3}$ Su objetivo es enfrentarnos a la exigencia de pensar una forma de relación entre los elementos alienados distinta al legalismo, sin renunciar a la comprensión filosófica, su doctrina metafísica y una posible teología, las cuales abrirían el horizonte de la totalidad de la experiencia, opuesta a la experiencia del totalitarismo.

Uno de los rasgos más significativos de esta propuesta, como indica el título del texto del Programa, es que no está siendo realizada sistemáticamente por Benjamin, sino que está por realizarse. Y ese tal vez es el meollo de todo su pensamiento: mostrar la posibilidad o al menos cuestionarse sobre cómo mostrar la posibilidad. Pero, ¿por qué no realizarla como tal? Porque representar positivamente su realización sólo la ridiculizaría, clausurando su posibilidad. El silencio sería la mejor forma de apuntar al ámbito que la filosofía trascendental abre a la experiencia. Ese silencio es lo que Benjamin entiende por el Mesías: "Sólo el Mesías logra él mismo todo devenir histórico". ${ }^{4}$ Nada del orden de lo empírico, imaginario o histórico, sin embargo, podría ocupar dicho lugar, y éste no cumple tampoco la función del telos de la historia. ¿Cómo puede entonces lograr algo en tal ámbito, si él mismo no es histórico? "Históricamente, él no es una meta, es un término". ${ }^{5} \mathrm{El}$ Mesías es la representación del evento que realizaría el devenir histórico, más allá de la lógica de los eventos históricos. Un evento que, además, debe ser concebido en un acto de felicidad: "Porque en la felicidad todo lo que es terrestre aspira a su anulación, pero es sólo en la felicidad que esta anulación le es prometida". ${ }^{6}$

${ }^{3}$ Ibid., p. 190.

${ }^{4}$ Walter Benjamin, "Fragment théologico-politique", en Euvres, 2000, Paris, Gallimard, vol. I, p. 263.

${ }^{5}$ Ibidem.

${ }^{6}$ Ibid., p. 264. 
Pero, ¿eso significa que hemos de estar dispuestos a arriesgar nuestra identidad en un momento de felicidad? La posibilidad del momento mesiánico envuelve una resistencia contra sí mismo, por una buena razón: "la intensidad mesiánica inmediata del corazón, de cada individuo en su ser interior, se adquiere a través del infortunio, en el sentido del sufrimiento". ${ }^{7}$ El señalado momento de felicidad implica una forma negativa de representación; no sólo en el silencio, sino en el sufrimiento. El deseo, al enfrentarse a la posibilidad de la experiencia superior, se revela en parte como uno negativo, de contención de las consecuencias; pero, al orientarse al Mesías, está dispuesto a sufrir por una posibilidad de realización positiva superior, aunque por determinar.

¿Dicha posibilidad, entonces, apunta a una especie de catarsis? Es prematuro afirmarlo, pero hay varias similitudes, entre ellas, que dan término a una historia; no en el sentido de que ahí concluya, sino en que ahí se resuelve el conflicto. ${ }^{8}$ Lo que hemos de comprender, por tanto, es qué tipo de representación es ésta y cuál es el transcurso que lleva a ella.

En su texto El narrador, Benjamin se ubica en este proceso al analizar las implicaciones de dejar atrás la tradición oral y privilegiar los medios impresos para comunicarnos. Si la narración era la forma por excelencia de trasmitir la experiencia por vía oral, alejarnos de ella abre la posibilidad de una nueva experiencia, análoga, a mi parecer, a la que posibilita la crítica trascendental, cuya articulación buscamos realizar. Sin embargo, Benjamin plantea un problema: si la narración era la base de la facultad de intercambiar experiencias, al alejarnos de la tradición oral, la cotización de la experiencia se devalúa. Inclusive, compara esta depreciación con la de los combatientes que regresaban de la Primera

\section{${ }^{7}$ Ibidem.}

${ }^{8}$ En las Tesis de Filosofía de la Historia de Benjamin, ese momento, aun cuando no resuelva en sí mismo los conflictos históricos, configura la promesa de su posible reconciliación. Al respecto, consultar el tercer apartado del sexto capítulo, dedicado al mencionado texto de Benjamin, en Carlos A. Garduño Comparán. Arte, psicoanálisis y estética: promesa de reconciliación. La falta de evidencia del arte contemporáneo y su derecho a la existencia, 2012, Castelló de la Plana, Publicacions de la Universitat Jaume I. 
guerra mundial sin nada qué contar. ¿Será acaso que al establecer un orden trascendental, que se aleja de lo empírico, dejamos de contar con experiencias significativas que compartir? ¿Nos encontramos como recluidos en nuestras estructuras legales y subjetivas, sin contacto con los otros?

Los modelos del narrador de la Antigüedad son, para Benjamin, el marino mercante, el campesino y el artesano. Hombres que, viajando o establecidos en un lugar, pueden relatar el producto de su experiencia en tanto que su trabajo diario implica contacto directo con ella. Es decir, su experiencia y su trabajo no se distinguen, son uno mismo. No han sufrido la alienación de la división del trabajo posterior. El ejemplo de narrador que Benjamin privilegia es el ruso Nikolái Leskow, por su oposición a la burocracia eclesiástica y temporal, y por privilegiar como fuente de sus relatos las leyendas de las regiones rusas. Su protagonista principal, nos recuerda Benjamin, encarna el modelo del "justo", el hombre sencillo que de manera natural es prácticamente un santo; cuyo trabajo se funde en armonía con la naturaleza y que carece de la compulsión a los excesos: "Su modelo es el hombre que se siente a gusto en el mundo sin entregarse excesivamente a él". ${ }^{9}$ Así, las narraciones de Leskow son básicamente costumbristas, porque en las cos12 tumbres de esta gente sencilla encuentra todo lo que vale la pena narrar. No hay necesidad de configurar un momento sublime, extraordinario o mesiánico, porque lo extraordinario se confunde con lo común. Estamos, pues, en el nivel mágico del lenguaje, en que la palabra expresa una unidad inalienable con la cosa.

La orientación de este tipo de narración es completamente práctica, no en el sentido kantiano de una fundamentación trascendental de las costumbres, sino de sabiduría práctica, de consejos en relación a la utilidad directa, empírica, cuyas expresiones son la moraleja, el proverbio o la regla de vida. El punto aquí es que "el narrador es un hombre que tiene consejos para sus lectores". ${ }^{10}$ Por ello, mientras más nos alejamos del ámbito de la narración, nos dice Benjamin, quedamos desasistidos de

${ }^{9}$ Walter Benjamin, “The Storyteller”, en Illuminations, 1968, New York, Harcourt, Brace \& World, p. 86.

${ }^{10}$ Ibidem. 
consejo. Pero, ¿qué función cumple el consejo en la representación de la realidad? ¿Qué perdemos en el proceso de alienación?

El consejo no es tanto la respuesta a una cuestión como una propuesta concerniente a la continuación de una historia en curso. Para procurárnoslo, uno tendría que ser capaz de narrarla. (Sin contar con que el hombre sólo se abre a consejo en la medida en que permite expresar su situación). El consejo es sabiduría entretejida en los materiales de la vida real. El arte de narrar se aproxima a su fin porque el aspecto épico de la verdad, la sabiduría, se está extinguiendo. Esto, sin embargo, es un proceso que se ha venido dando desde hace mucho. Y nada sería más fatuo que querer ver en él un mero "síntoma de decadencia", sin mencionar un síntoma "moderno". Se trata, más bien, de un síntoma concomitante de las fuerzas productivas seculares de la historia, un acompañante que paulatinamente ha desplazado la narración del ámbito del discurso vivo, y que al mismo tiempo está haciendo posible ver una nueva belleza en lo que se está desvaneciendo. ${ }^{11}$

Lo que perdemos, en primera instancia, es la capacidad de proponer cómo continuar la historia, como si la historia continuara por sí misma sin tomar en cuenta nuestras propuestas y experiencia. Se pierde, en consecuencia, la capacidad de articular nuestra situación en palabras, dando paso a una articulación legal a priori. Llama la atención, sin embargo, que en este proceso Benjamin vea, más que un progreso, que la sabiduría se está extinguiendo, abriendo paso a nuevas posibilidades que no deben ser vistas como una forma de decadencia, ni como algo específicamente "moderno". Tal como indiqué sobre el Programa de la filosofía venidera, se trata de un proceso cuyas nuevas experiencias están por ser comprendidas, agregando que su origen viene de muy atrás y que tiene que ver con la transformación de las fuerzas de producción, en la que se desplaza el acento de la narración, del habla a la escritura.

Una de las innovaciones técnicas clave en este largo proceso histórico es la imprenta, la cual marca el surgimiento del libro y de la novela como relevo de la épica y sus formas narrativas. La diferencia fun-

${ }^{11} I b i d .$, p. 87. 
damental, piensa Benjamin, es que mientras el narrador toma el material de sus experiencias y lo comparte con quienes convive, el novelista está aislado y no comparte directamente su experiencia con nadie; de hecho, la inventa. Estamos, pues, ante el surgimiento de la ficción y de la conciencia de la representación imaginaria de la realidad, la cual posibilita la alienación del escritor del mundo empírico. En consecuencia, el novelista es ya uno de estos hombres desasistidos de consejo; sería absurdo leer una novela en busca de algún tipo de indicación que podamos aplicar en nuestro trabajo cotidiano. "Escribir una novela significa llevar lo inconmensurable a los extremos en la representación de la vida humana". ${ }^{12}$ Su mensaje es, más bien, trascendental; es decir, no está comunicando nada en específico, lo cual hace más urgente comprender qué podría estar comunicando entonces, si es que está comunicando algo.

La primera gran novela, nos dice Benjamin, es Don Quijote. Este noble, contrario a los héroes de las epopeyas, no es heroico; no supera a las fuerzas míticas; en todo caso, es un héroe desmitificado, casi ridiculizado. Con él no sólo se pierde todo consejo, sino todo modelo; el Quijote ya cruzó las fronteras de la cordura: está fuera de cualquier ámbito práctico. ¡Quizás en ello radica su grandeza! Si lo que buscamos es comprender la promesa que abre el ámbito de representación trascendental, tal vez justo en la locura del Quijote tendría que hurgar el filósofo.

Ahora bien, otra de las formas que pone en crisis la narración, según Benjamin, es el periodismo, introduciendo la información como forma de comunicación. Ésta privilegia la proximidad de los eventos en el espacio y tiempo como base de su autoridad, recurriendo a explicaciones detalladas para sostenerla. En la narración y la novela ocurre lo contrario: no es necesario explicar a detalle ni poner a la vista los objetos. Pero en la información sucede una especie de proceso doble: nos separa del mundo empírico para luego reducir la distancia lograda en el ámbito trascendental. Es, pues, como un tipo de ficción que percibimos como realidad inmediata y que se sostiene en la legalidad de su explicación,

${ }^{12}$ Ibidem 
como una especie de evidencia pseudo-científica. Por ello, en realidad, la información no genera sorpresa y reflexión; no es propicia para dar consejos, ni para la contemplación. Tan sólo se puede usar, pero sin el apoyo de una forma de sabiduría.

Lo que tenemos con la información es que dimos un paso más en relación a la filosofía kantiana y nuestros intereses de comprensión trascendental. Su inmediatez implica no sólo la incapacidad de transmitir experiencias, como sucedía con la novela, sino con la de estructurar una forma de memoria. La estructura de la novela, aunque ficticia, es análoga a la de la historiografía. La información, en cambio, carece de ella; es instantánea; no requiere ser vinculada a una totalidad histórica para consumirse. Benjamin, utilizando una expresión de Valéry, nos hace ver que el "hombre moderno ya no trabaja en lo que no puede ser abreviado", ${ }^{13}$ lo cual coincide con una especie de descontinuación del concepto de eternidad que, para Benjamin, tiene que ver con un cambio de actitud hacia la muerte. Más allá del consejo, se ha perdido el carácter ejemplar de la muerte. Se ha vuelto un concepto vacío, un término que no nos dice nada.

La narrativa épica, piensa Benjamin, mantenía una relación cercana con la muerte que favorecía la rememoración, porque privilegiaba las formas de memoria de larga duración y el transcurrir y declinar de los acontecimientos más que los eventos puntuales. Por ello, nos dice, la épica configuraba una red de historias que daba forma a la tradición, y su musa era Mnemósine. La novela, en cambio, al centrar la atención en el protagonista, favorece la dispersión de los acontecimientos, disociando sentido y vida. Aun así, en la novela se mantienen presentes ambos elementos, con lo que la muerte se puede plantear al menos como un problema; como horizonte trascendental a ser reflexionado. El problema es que, si el sentido de la vida del personaje en la novela "sólo es revelado a su muerte", ${ }^{14}$ la muerte y el sentido en realidad estuvieron ausentes de la trama y sólo se presentaron hasta su final. “¿Cómo es que los personajes le hacen entender que la muerte ya espera por ellos

${ }^{13}$ Ibid., p. 93.

${ }^{14}$ Ibid., p. 101. 
-una muerte determinada y en un punto determinado? Esa es la pregunta que alimenta el voraz interés del lector por los eventos de la novela". ${ }^{15}$ La estructura en la novela apunta hacia ese momento, que concentra todas las expectativas del lector. Esperar tanto de un solo instante, sin embargo, tal vez sólo lleve a la desilusión; a la misma desilusión de la información y el periodismo, que no teje las experiencias en una narración para dar consejo y crear tradición; que no tiene nada que compartir y que tampoco tiene deseo de realizar las posibilidades que se le presentan. Únicamente posee datos, que repite mecánicamente.

La experiencia se devalúa en la misma medida en que la memoria y tradición se reducen a información, a datos históricos que ya no tienen que ver con el trabajo ni la satisfacción de los individuos. La pregunta del programa de filosofía por venir tal vez pueda ser planteada de la siguiente manera: ¿cómo representar un pasado que permita abrir un horizonte de satisfacción a futuro, sin reducir la memoria a narraciones costumbristas o a mera información? La legalidad de la estructura trascendental se ha de mantener, pero como tarea principal se debe desarrollar la comprensión de las experiencias hacia las que apuntan todas las expectativas ligadas a ella. Pues, si se reducen a la locura o a la muerte, ¿qué esperanzas podría ofrecer? La consecuencia

16 de esta indeterminación, ¿no es precisamente la desilusión de la información? Así, en un sentido muy kantiano, la pregunta de la metafísica del porvenir, en estrecha relación con la teología es ¿qué podemos esperar? Y su respuesta no podrá ser la moral como determinación racional de los fines, ni tampoco la total indeterminación de los fines. Otro tipo de representación, entre la determinación y la indeterminación, deberá ser planteada.

La pregunta ha de cuestionar sobre el porvenir, en oposición al destino. Éste, para Benjamin, no debe ser entendido en un sentido inocente, sino como "la tentación de la más pesada de las faltas, aquella de la hybris". ${ }^{16}$ Hay en él una mediación moral que modifica el valor de la experiencia temporal, enfrentándonos al oscuro trasfondo de la desmesura, el mal. En su horizonte, la felicidad sólo puede concebirse como

${ }^{15}$ Ibidem.

${ }^{16}$ Walter Benjamin, “Destin et caractère”, en CEuvres, 2000, Paris, Gallimard, vol. I, p. 201. 
"lo que libera al hombre del encadenamiento de los destinos y de la red de su propio destino"; ${ }^{17}$ como la expresión negativa del destino. Pero, tal liberación ¿no equivaldría a una especie de anulación de las estructuras en las que se asienta la razón? ¿No implicaría una especie de regresión? Benjamin muestra que la felicidad ha de ser representada más allá de la esfera del destino, siendo éste el lugar de la culpa fundada sobre formas legales. Tal esperanza, así, deberá ser pensada en el ámbito de la religión, como una forma de trascendencia. Pero, para poder seguir prometiendo, deberá conservar aquello de lo que se ha de liberar para realizarse, el destino, la legalidad. Estamos, pues, ante un impasse. Ahora bien, Benjamin señala que la primera representación en la que la esperanza de superar el destino fue mostrada - por lo que se podría considerar que abrió el camino para la superación del estilo épico-, es la tragedia griega:

$[\ldots]$ en la tragedia $[\ldots]$ la cabeza del Genio emergía por primera vez de las brumas de la falta [...] No, sin embargo, en el sentido en que el encadenamiento de la falta y la expiación, que para el pagano se reproduce al infinito, será roto por la pureza del hombre que se ha expiado y reconciliado con el Dios puro. En la tragedia, el hombre pagano se da cuenta de que él es mejor que sus dioses, pero este saber le anuda la lengua, permanece sordo. ${ }^{18}$

En la tragedia, el griego representó por primera vez la posibilidad de superar el destino, sin poder representar el momento de redención. Quizás precisamente porque no tenía posibilidad de comprender el ámbito de representación trascendental que en realidad lo mantenía atado a la culpa; el destino entendido como la moral que determina, a priori, los fines: "La paradoja del nacimiento del Genio en la ausencia de lenguaje moral, en la infancia moral, he ahí lo sublime de la tragedia. Tal es verdaderamente el fundamento de todo lo sublime, donde se manifiesta el Genio, más bien que Dios". ${ }^{19}$ La tragedia, pues, aunque

${ }^{17}$ Ibid., p. 202.

${ }^{18}$ Ibid., p. 203.

${ }^{19}$ Ibidem. 
muestra la posible superación del destino, carece del lenguaje para representar la felicidad.

Específicamente, el griego carecía del lenguaje que mostrara que la culpa en la que el destino nos sume no tiene que ver con un mal efectivamente realizado y la consecuente necesidad del castigo, sino con que el derecho de entrada nos condena a ser culpables; que el "destino es el conjunto de relaciones que inscribe al ser vivo en el horizonte de la falta". ${ }^{20}$ Que se trata, pues, de una culpa trascendental, con una temporalidad distinta a la de la experiencia vivida: "es un tiempo que todavía no subsiste por sí mismo, que parasita el tiempo de una vida superior, menos ligada a la naturaleza. No tiene presente". ${ }^{21}$ Por tal carencia, la tragedia sólo puede representar el conflicto de los tipos de temporalidad y acercarse a la redención en un clímax catártico, sin mostrarla.

Curiosamente, sin embargo, Benjamin nos señala que en un ámbito distinto a la articulación del conflicto, los griegos representaron el elemento que no se deja atrapar por el destino: el carácter. Éste tiene que ver con la naturaleza del individuo y sus rasgos en un sentido moralmente indiferente, y es el centro en torno al cual se configura la comedia. En ella, el personaje no es objeto de condena moral, sino de hilaridad, porque sólo se muestran sus rasgos de carácter en sí mismos: "la sublimidad de la comedia de carácter reposa sobre el anonimato del hombre y de su moralidad, al mismo tiempo que el individuo se encuentra transportado a su más alto desarrollo en la unicidad de un rasgo de carácter". ${ }^{22}$ En virtud de ello, pareciera que el personaje cómico está liberado de las complicaciones del destino, como portador de la simplicidad que su carácter implica, "de la inocencia natural del hombre". ${ }^{23}$

¿Por qué, sin embargo, esta especie de beatitud, al enfatizar el rasgo que define el carácter del personaje, no puede ser igualada a la redención mesiánica que buscamos? El héroe cómico se parece más bien al Quijote, y su aparente liberación del destino no ofrece posibilidades prácticas. En cierto sentido, de hecho, confirma que la alienación no

${ }^{20}$ Ibid., p. 204.

${ }^{21}$ Ibid., p. 205.

${ }^{22}$ Ibid., p. 207.

${ }^{23}$ Ibid., p. 208. 
tiene respuesta. Que debemos escoger o lo cómico o lo trágico, la legalidad o la sabiduría empírica, a costa de asumir la culpa o el aislamiento de una presunta pureza de carácter poco funcional en el terreno de las formas trascendentales.

El problema, entonces, quizá radica en encontrar el lenguaje de lo que en la tragedia parece mostrarse sin palabras, a saber, que lo que "decide, en efecto, sobre la legitimidad de los medios y la justificación de los fines, no es jamás la razón, sino, primero, una violencia que tiene el carácter de un destino y, después, Dios mismo". ${ }^{24}$ Es decir, quizás la representación del momento mesiánico deba ser precedida por una crítica de la ideología y de su violencia. Una especie, tal vez, de crítica al dogmatismo, que sea capaz de responder a las formas de autoritarismo que ha engendrado el orden trascendental y sus pretensiones totalizadoras.

¿Cómo concebir la violencia fundadora que impone el destino culposo? Como la cólera de Dios. No como su voluntad o como los medios para realizarla, sino como "manifestación de su existencia". ${ }^{25}$ Pero, ¿por qué esta manifestación violenta no es equivalente al momento mesiánico que puede dar término a la historia como resolución del conflicto? Porque esta violencia más bien lo inaugura. De hecho, para Benjamin, tal es el principio de toda formación mítica del derecho; la fundación de una ley igual para todos, en condiciones desiguales; la imposición del orden por la fuerza y no asumido libremente; que se impone como destino aunque se desconozca, como en la tragedia.

En contra, la violencia divina del momento mesiánico, más que fundadora de un estado de derecho que se impone como destino, destruye dicho estado: "la violencia divina lava la falta". ${ }^{26} \mathrm{Si}$ la violencia mítica impone el derecho sometiendo al individuo, la violencia divina “es mortal” y "ejercida en favor del ser vivo contra toda vida. La primera exige sacrificio, la segunda lo acepta". ${ }^{27}$ Se nulifica, entonces, la forma

${ }^{24}$ Walter Benjamin, "Critique de la violence”, en Euvres, 2000, Paris, Gallimard, vol. I, p. 233.

${ }^{25}$ Ibid., p. 234.

${ }^{26}$ Ibid., p. 238.

${ }^{27}$ Ibidem. 
legal de la estructura trascendental, pero no la estructura en sí, porque se mantiene la necesidad del sacrificio. Uno aceptado, sin embargo, en una especie de reconciliación entre la vida y la muerte. ¿Cómo entender, entonces, esta aceptación del sacrificio? ¿Cómo podemos representar la posible satisfacción involucrada en ello? La crítica de la violencia nos puede llevar a ese lugar, pero la complicación es que dicho momento no puede ser comprendido en el marco de una intención determinada y de una decisión voluntaria: "no es ni posible ni urgente para los hombres decidir cuándo una violencia pura fue efectiva en un caso determinado [... ] porque la fuerza de la violencia, la de poder lavar la falta, no se manifiesta a los ojos de los hombres". ${ }^{28}$ Pareciera que ese momento de violencia pura, mortal pero no sanguinaria ni discrecional, no es susceptible de representación, al menos de manera positiva o imaginaria. Que, de hecho, no se puede planear, sino que acontece. Pero, ¿por ello debe ser pensado como indeterminado? Quizá sólo conceptualmente, aunque tal vez existe la posibilidad de determinarlo por medio de otra forma de representación.

El pensamiento de Hannah Arendt, cercano al de Benjamin, podría darnos una pista. En su texto Ideología y Terror, hace notar que la lógica del totalitarismo se basa en la forma de razonamientos deductivos tras los cuales se oculta el terror como principio real del sistema, y que ello es posible porque confunde distintos niveles de representación. El principio lógico deductivo se expresa en general de la siguiente manera: Si uno enuncia $A$, entonces uno necesariamente debe enunciar $B$. Se trata, pues, de la mera forma de una condición expresable directamente en lenguaje simbólico. Sin embargo, la frase con la cual comunica dicho principio un líder totalitario, es: "uno no hace omelettes sin romper los huevos". ${ }^{29}$ Trasladada a su forma lógica, la frase equivale a algo absurdo en términos de sentido común y experiencia inmediata: Si hay huevos, entonces hay que romperlos. Pero la masa no lleva a cabo esta reflexión. Lo que reciben directamente del líder es una orden, la cual ejecutan al pie de la letra. ¿Por qué? Porque "ella es manifies-

${ }^{28}$ Ibid., p. 242.

${ }^{29}$ Hannah Arendt, Idéologie et terreur, 2008, Paris, Hermann, p. 98. 
tamente idéntica a nuestro miedo de caer en contradicciones, y de perdernos a nosotros mismos a causa de ellas". ${ }^{30}$ Porque el lugar desde el cual es proferida la frase no es neutro. El lugar de enunciación del líder está vinculado a una situación amenazante, a su capacidad de ejercer violencia efectiva. Lo que recibe la masa no es sólo la orden, sino la amenaza implícita al lugar de enunciación; y su reacción, en consecuencia, no sólo es la de la coherencia del pensamiento deductivo, sino la del miedo a no ser coherente con la orden. Su sentido común, que aconseja evitar el peligro, se confunde con el orden trascendental del principio lógicodeductivo, impidiéndoles reflexionar sobre posibles nuevas experiencias e inhibiéndoles para arriesgarse a realizarlas.

Entonces, si el sistema totalitario es una forma de terrorismo, y lo que organiza a las masas es el "miedo de encontrarse en contradicción consigo mismo y con toda su existencia" ${ }^{31}$ - un miedo análogo al de la muerte y la locura-, su posible superación está precisamente en enfrentar la muerte y la locura, la contradicción y la falta de coherencia en la existencia; no tanto perdiéndoles el miedo, sino logrando que el miedo no sea el principio que determine nuestra relación con ello. Y la manera de lograrlo es encontrando la forma de representar aquello que tememos, interiorizándolo más allá de la figura del sistema, como un lugar de posible superación. Interiorizando, pues, la esperanza sobre el terror.

Así, por ejemplo, si la fórmula del partido comunista era: "puesto que eres un bolchevique convencido, sabes que el partido siempre tiene razón", ${ }^{32}$ su posible superación, como en cualquier forma de argumentación, está en no aceptar la premisa fundamental de la cual se deriva la deducción, a saber: yo soy un bolchevique convencido. Por supuesto, la dificultad no radica simplemente en negar la proposición en términos lógicos, sino en el miedo que nos ocasiona porque, al hacerlo, ¿qué nos quedará para representar nuestra identidad? Justo ese qué nos quedará es lo que debe ser representado como el Mesías; como

${ }^{30}$ Ibidem.

${ }^{31}$ Ibid., p. 99.

${ }^{32}$ Ibidem. 
aquello por venir, pero que también permanece como una posibilidad latente; que puede realizarse en cualquier instante, a lo largo de toda la historia. ${ }^{33}$

Ahora bien, lo que me interesa aquí no es sólo la posibilidad lógica del momento mesiánico como una dimensión histórica, sino su representación efectiva, porque sólo ello permitiría mostrarlo a las masas y convencerlas de que hay algo más; la posibilidad, por tanto, de que en función de una forma de representación dejen de funcionar como masas, abriéndose a otro horizonte. Para Arendt, el único principio que permitiría resistir al miedo es la espontaneidad, entendida como la capacidad de "retomar las cosas desde el comienzo"; 34 como libertad creadora a partir de la cual, sin un principio previo, surgen nuevos principios en la acción común de los hombres, como expresión de su voluntad. ¿Esto significa que la espontaneidad, en la ausencia de principios, implica que se puede actuar sin la determinación de algún tipo de representación? ¿Que no es necesaria una forma de representación y que las masas en algún momento actuarán espontáneamente en un evento liberador? Por supuesto, privilegiar la espontaneidad sobre cualquier principio apunta a la necesidad de que los individuos se arriesguen a actuar más allá de los imperativos del sistema de organización. Pero, ¿el riesgo se toma así nada más? ¿En el vacío, en la indeterminación? ¿No será que la ausencia de representación más bien consolidará el terror y la inhibición?

Para Arendt, la experiencia del totalitarismo es la de desolación y no se iguala a la soledad. ¿No depende esta distinción de dos tipos de representación distintos? En la desolación, un hombre "deduce sin parar una cosa de otra y piensa todo en la perspectiva de lo peor". ${ }^{35} \mathrm{Su}$

${ }^{33}$ En sus Tesis sobre la filosofia de la historia, Benjamin articula esta posibilidad como un momento teológico que debe complementar al materialismo histórico como su contenido de verdad. Para más referencias, consultar el tercer apartado del sexto capítulo de Carlos A. Garduño, Arte, psicoanálisis y estética ..., op. cit.

${ }^{34}$ Ibid., p. 100. La referencia a partir de la cual Arendt discierne esta facultad es San Agustín, apoyándose en la frase Ut initium esset, homo creatus est. Lo que le importa a Arendt es retomar la noción de que la fuente de la libertad está al comienzo de las cosas, como su acto creador.

${ }^{35}$ Ibid., p. 115. Arendt utiliza aquí la respuesta de Lutero a la cuestión “¿Por qué huir de la soledad?", en sus Escritos de edificación. 
representación, por tanto, produce temor, al esperar tan sólo lo peor. En cambio, en la soledad:

Yo no estoy jamás solo; estoy conmigo mismo, y este yo mismo que no puede ser jamás físicamente intercambiado con algún otro, es también cada uno. Un pensamiento solitario es precisamente dialógico y en comunidad con todo el mundo. Esa es la ambigüedad de la soledad: en ella me refiero siempre a mí mismo sin jamás poder experimentarme como una singularidad en la que la identidad no sabría ser confundida y permanecería verdaderamente unívoca. ${ }^{36}$

En la desolación, los hombres están abandonados, aislados de los otros, sin consejo, y tan sólo cuentan con principios lógicos para deducir consecuencias. En la soledad, en cambio, mi identidad es reafirmada por los otros, en la experiencia de un diálogo constante que define los límites de cada uno. Lo primero favorece la formación de masas de los regímenes totalitarios, pues ellas no son más que conjuntos de individuos que no interactúan realmente entre ellos, porque desconfían uno del otro. Lo segundo es la consolidación de la identidad, al arriesgarse a ser afectado por el otro, en un acto de confianza y verdadera fe. Lo que hemos de comprender, por tanto, son los distintos tipos de representación, de uno mismo y del otro, en las experiencias de soledad y desolación.

Para ello, la imagen del Angelus Novus de Paul Klee, que Benjamin llama el Ángel de la historia, ${ }^{37}$ me parece ilustrativa. Según Benjamin, el ángel contempla horrorizado las catástrofes del pasado; pero, a su vez, "quisiera detenerse, despertar a los muertos y recomponer lo destruido". ${ }^{38}$ El ángel, ¿está solo o desolado? Por supuesto, nada en su apariencia física podría decírnoslo, pues la distinción no es del orden de lo imaginario. Ciertamente, por sus rasgos, podríamos suponer que está aterrado. Pero, ¿su terror es el mismo al que están sometidos los individuos en el totalitarismo? ¿O su terror puede generar esperanzas?

${ }^{36}$ Ibid., p. 119.

${ }^{37}$ En la tesis IX de su texto Tesis de la filosofía de la historia.

${ }^{38}$ Walter Benjamin, Tesis sobre la historia y otros fragmentos, 2008, México, Ítaca, p. 44. 
Evidentemente, si el ángel quiere hacer justicia a las víctimas, es la última opción la que corresponde con la interpretación de Benjamin. ¿En qué radica, entonces, la esperanza de su terror? A mi parecer, en que no es indiferente al dolor ajeno. Que su miedo no tiene que ver con ser excluido, con no ser coherente, sino con que es testigo de que hay quienes han sido excluidos y desea acercarse a ellos para cobijarlos. El Angelus Novus, bajo esta interpretación, no está desolado. No nos observa desde su nicho trascendental como una divinidad decepcionada de la humanidad, abandonándonos. Está, en todo caso, solo, pero dispuesto a auxiliarnos. Se define en relación al otro, que somos todos y cada uno de nosotros.

A mi parecer, las formas de representación implícitas en la soledad y la desolación nos permiten comprender los distintos horizontes que posibilita la estructura trascendental. En otras palabras, la soledad y la desolación representan los dos modos en que podemos relacionarnos con nosotros mismos, en tanto que nuestra identidad se define en función de una ley que ha llegado a establecerse en un ámbito independiente de la experiencia; más allá, por tanto, de cualquier identificación imaginaria. Y la distinción radica en la manera en que este horizonte, que no puede ser mostrado bajo los principios del espacio y el tiempo, es

24 representando para uno mismo: como otro del cual hay que defenderse porque es en sí mismo desconfiable -como en el totalitarismo-; o como otro al cual, a pesar del miedo, uno desea acercarse para acogerlo -como en el Angelus Novus.

La representación del horizonte trascendental como otro permite entender la vida práctica en función de un lugar que, al no poder ser llenado con contenido empírico, requiere de nuestro juicio para determinar la propia actitud y decisión ante ello. Que nos requiere, por decirlo de alguna manera, para hacernos cargo de él o para negarle nuestro cuidado, sin que podamos evadirlo, pues mientras nuestra identidad se sostenga en una estructura que no depende exclusivamente de las circunstancias, su lugar permanecerá como posibilidad. Queda, sin embargo, responder la siguiente cuestión: ¿En qué lenguaje nos requiere y cómo podemos responder a su llamado? ¿Cómo nos comunicamos con ese otro? 
En Sobre el lenguaje en general y el lenguaje humano, Benjamin afirma que toda manifestación del espíritu humano puede concebirse como un tipo de lenguaje, por lo que comprenderlo equivale a distinguir los distintos tipos de manifestación espiritual. Más específicamente, el lenguaje es el principio que sirve para comunicar contenidos espirituales. ¿Como cuáles? Lo primero que debemos entender es que "la esencia espiritual se comunica en el lenguaje y no por él". ${ }^{39}$ No hay un uso del lenguaje que exprese independientemente de su contenido, lo cual no quiere decir que no haya uso trascendental del lenguaje, porque bien puede haber un contenido trascendental. El lenguaje se comunica a sí mismo, es su esencia espiritual. Y, sin embargo, no es tautológico, porque su forma no es su contenido. El medio de su expresión, su forma de lenguaje, es la inmediatez de la comunicación de su esencia espiritual, que no difiere de él.

En ese sentido, el lenguaje propio del hombre es el de las palabras, ya que éste comunica su propia esencia espiritual nombrando las cosas. Y no sólo eso, sino que, esencialmente, sus palabras están dirigidas a Dios: "en el nombre la esencia espiritual del hombre se comunica a Dios". ${ }^{40} \mathrm{Su}$ particularidad, pues, es que al nombrar las cosas en su lenguaje, a su vez las comunica a Dios. La palabra humana, más que un medio, es un medium. Uno que universaliza lo que nombra, dándole una dignidad superior.

Las cosas y Dios mismo, por otro lado, también expresan su esencia espiritual en su propio lenguaje. Ambos son mudos, en tanto que no requieren la palabra; no nombran ni dan sentido. Su modo de expresión es la revelación, que se debe entender como interpelando al hombre: "Lengua, madre de la razón - dijo Hammann-, y revelación, su alfa y omega". ${ }^{41}$ Por supuesto, el hombre sólo conoce las cosas hasta que las nombra, pero, para ello, antes se le tuvieron que manifestar de alguna forma, en su propio lenguaje. Por ello, el lenguaje humano reposa en la manera en que la cosa se comunica al hombre.

${ }^{39}$ Walter Benjamin, "Sur le langage en général et sur le langage humain", en Euvres, 2000, Paris, Gallimard, vol. I, p. 144.

${ }^{40}$ Ibid., p. 147.

${ }^{41}$ Ibid., p. 151. 
En consecuencia, el lenguaje humano puede ser considerado una traducción de los otros lenguajes, siendo la traducción el pasaje de uno al otro a través de una serie de metamorfosis continuas. Así, el pasaje del lenguaje de las cosas al del hombre es la traducción de lo anónimo al nombre, porque Dios nos ha dado esa tarea. Nótese que a Benjamin no sólo le interesa mostrar que el lenguaje en general responde a diferentes niveles de representación heterogéneos, al grado de poder considerarlos lenguajes distintos o expresiones de esencias espirituales diversas, sino que el lenguaje humano ocupa un lugar intermedio, en tensión entre el lenguaje de la naturaleza y el de Dios: nombrando, en relación al primero; acatando su misión, en relación al segundo. El lenguaje humano, pues, aunque trascendental, no puede aislarse de su base empírica, ni de su horizonte divino. Todo esto, sin embargo, bajo la siguiente condición: ello "no será posible de cumplir si en Dios no fueran aparentes el lenguaje humano de los nombres y el lenguaje sin nombre de las cosas, salidos del mismo verbo creador, devenido en las cosas comunicación de materia en una comunidad mágica, en el hombre lenguaje del conocimiento y del nombre en un espíritu bendecido". ${ }^{42}$ La comunicación de los distintos ámbitos sólo es posible bajo tal jerarquía: tanto el orden mágico o empírico, como el legal o trascendental, 26 comparten el mismo origen en Dios; ambos devienen del verbo creador y hacia él se dirigen.

Cualquier forma de alienación que aísle alguno de los lenguajes del resto, impidiendo su traducción, está cerrando las posibilidades que esencialmente le corresponden. Por otro lado, el pasaje no se da en automático; hay una especie de retardo: "Este retardo infinito del verbo mudo en la existencia de las cosas en relación al verbo que, en el conocimiento del hombre, les da un nombre y, a su vez, de este verbo en relación al verbo creador de Dios, es lo que funda la pluralidad de lenguajes". ${ }^{43} \mathrm{El}$ número de lenguas existentes, por ello, equivale al número de traducciones realizadas.

Los otros, pues, del lenguaje humano -el lenguaje del nombre, simbólico, trascendental-, son el lenguaje mágico de las cosas y el de Dios,

${ }^{42}$ Ibid., p. 158.

${ }^{43}$ Ibid., p. 159. 
y sus posibles relaciones abren al hombre un amplio abanico de experiencias. La más significativa, en cuanto a ofrecer esperanzas, es la relación con el bien y el mal. Éstos, por supuesto, no se encontrarán por ningún lado en el orden de lo empírico, pero tampoco en el legal. Su noción apunta al origen compartido de ambos: el verbo creador. Por ello, no son cognoscibles; el pecado original es la desmesura del saber del bien y el mal; sin embargo, a pesar de la imposibilidad, ¿el hombre debe resignarse a su ignorancia y no arriesgarse a intentar adquirir ese saber? Ante esta decisión, que requiere de nuestro juicio, estamos solos. Dios nos lo impone al no dar una respuesta; a ello equivale la condena del tribunal que expulsó al hombre del Paraíso. Y en esa decisión radica la diferencia entre la soledad y la desolación.

Como sea, en tal decisión no estamos desamparados. Nos asiste una facultad creativa, poética; no creadora como el verbo divino, sino mimética. En el hombre, según Benjamin, toda función superior está condicionada por ella. Desde el juego de los niños, en el que imitan a los adultos, la naturaleza y los objetos, hasta las formas de organización social que imitan el orden cósmico, la mímesis determina el rumbo de la historia. Pero, ¿qué es exactamente lo que imita el hombre? ¿Qué es lo que le permite realizar el pasaje de un lenguaje a otro? Lo que Benjamin llama la semejanza no sensible. Ésta, es la asociación de "lo dicho y el sentido aludido, pero también, lo escrito y el sentido aludido, y paralelamente lo dicho y lo escrito". ${ }^{44}$ Imitar es, como en el acto de escritura, establecer un archivo de signos, los cuales son los representantes de aquello imitado, inscribiendo una semejanza no sensible. La mímesis es, por tanto, la instauración de esta semejanza entre una palabra y la cosa con la que se relaciona, lo cual presupone un soporte semiótico, la inscripción de signos, que al presentar su semejanza, aparecen como "una iluminación instantánea". ${ }^{45}$ Propiamente hablando, aquí surge la metáfora: en una función del lenguaje que no es originaria, sino de segundo orden, que nos auxilia en el juicio sobre

${ }^{44}$ Walter Benjamin, "Sur le pouvoir d'imitation”, en Euvres, 2000, Paris, Gallimard, vol. II, p. 362.

${ }^{45}$ Ibidem. 
la decisión que hemos de tomar frente al horizonte de posibilidad trascendental: "un médium en el que han mudado integralmente las antiguas fuerzas de creación y recepción mimética, al punto de liquidar los poderes de la magia". ${ }^{46}$ La metáfora es, pues, el medio que el lenguaje brinda al hombre que ha ingresado al orden legal, sustituyendo a la magia de las sociedades regidas por el mito, para juzgar sus posibilidades.

Por supuesto, la facultad mimética se manifiesta en todos los rubros de la actividad humana, como un soporte de sus anhelos y deseos, y la mayoría de los ensayos de Benjamin son una exploración de cómo todo tipo de objetos a nuestro alrededor hablan de ello. A reserva de profundizar en tales reflexiones, bastarán aquí dos observaciones para finalizar: sobre la traducción y sobre el coleccionismo.

En La tarea del traductor, Benjamin muestra que la traducción no tiene que ver con una forma de trasmitir la información contenida en un objeto original, sino en un modo de expresión de su naturaleza, con lo que el traductor sólo ofrece el sostén para dicha expresión, cuya posibilidad permanece latente en el objeto. En ese sentido, labor del traductor es llevar a cabo una función mimética por medio de la cual permita la conexión natural - que es, a su vez, histórica- entre el objeto y su traducción, en tanto modo de expresión que posibilitará su continuidad en el tiempo como parte de una tradición. La labor del traductor debe servir, por tanto, a la finalidad propia de la esencia del original, sin determinarla con sus propias intenciones. Debe ofrecer un lugar en su lenguaje para acoger al otro, respetando su particularidad: "La traducción por tanto sirve en último término al propósito de expresar la relación central recíproca entre lenguajes. No tiene la posibilidad de revelar o establecer esta función oculta por sí misma; pero puede representarla al realizarla en forma embrionaria o intensiva". ${ }^{47}$

La representación que la traducción ofrezca al original, por supuesto, no puede basarse en una apariencia semejante. La semejanza debe ser inmaterial o trascendental. Implica, pues, la transformación de

${ }^{46}$ Ibid., p. 363.

${ }^{47}$ Walter Benjamin, "The Task of the Translator", en Illuminations, op. cit., p. 72 
la apariencia del original. Pero, ¿qué conserva? ¿Dónde reside la relación entre dos lenguajes si no es en su apariencia? En la forma de la intención; la traducción busca sacar a la luz la intención no aparente del texto: "apunta hacia esta región: el predestinado, hasta ahora inaccesible reino de reconciliación y cumplimiento de los lenguajes", ${ }^{48}$ más allá de la transmisión del tema o la información. En consecuencia, la traducción eleva el lenguaje. Su campo de acción es la totalidad del lenguaje, sus intenciones, sus anhelos, y no sólo en un contexto específico, como en el que fue creado el original.

La traducción, entonces, apunta a la reconciliación de las lenguas, en la acogida del otro, aun y cuando siempre permanezca algo en el original que no pueda ser traducido; un núcleo intransferible que, sin embargo, la traducción debe evocar, reafirmando su deseo de hospedarlo en el seno del propio lenguaje. En este sentido, la traducción es una búsqueda de "la lengua verdadera", análoga a los esfuerzos de la filosofía por aclarar la verdad, por lo que puede ser considerada un género autónomo - a pesar de su carácter derivado-y no utilitario, por no estar sometido a criterios funcionales.

Tal aspiración de configurar una lengua verdadera en la que los lenguajes se reconcilien, en realidad implica una especie de paradoja, porque para lograr expresar la supuesta intención del original, en una lengua ajena, pareciera que la traducción se tiene que alejar del sentido del primero, tendiendo más bien a un lenguaje puramente formal. No obstante, nos dice Benjamin, en el trabajo del lenguaje en relación a la mera forma de la intención del original -su literalidad, su objetualidad, y no su imagen o apariencia-, los límites del lenguaje del traductor se amplían. No se trata de adaptar el lenguaje del original al del traductor, sino de que éste sea afectado por el original: "debe regresar a los elementos primordiales del lenguaje mismo y penetrar en el punto donde trabajo, imagen y tono convergen". 49

La traducción es, por tanto, básicamente un trabajo sobre la forma de la estructura trascendental de dos lenguas en un intento de hacerlas

${ }^{48}$ Ibid., p. 75.

${ }^{49}$ Ibid., p. 81. 
coincidir en relación a las intenciones -y no apariencias o significadosde una obra en particular. El peligro es que, en el proceso, la traducción se aleje del sentido del original, incluso hasta perderlo por completo. "Donde un texto es idéntico a la verdad o al dogma, donde supone ser 'el verdadero lenguaje' en toda su literalidad y sin la mediación de significado, este texto es incondicionalmente traducible" ${ }^{50}$ El lenguaje puro, verdadero, sería dogmático, carecería de sentido y sería absurdo traducirlo, pues en su trascendentalidad, perdería toda relación no sólo con cualquier original, sino con todo intento de acogerlo en una lengua. Evidentemente, la reconciliación lograda dejaría de tender a la reconciliación. La traducción perfecta perdería su relación con el otro. Y, quizá, más que sola, quedaría desolada.

Bajo esta perspectiva, la traducción puede ser entendida como un acto análogo al de coleccionar, en el sentido de ofrecer un lugar a objetos cuyos contextos están ausentes, para reactualizar su esencia, valor e intenciones: "para un coleccionista -y quiero decir un coleccionista real, un coleccionista como debería ser- la propiedad es la más íntima de las relaciones que uno puede tener con los objetos. No que ellos adquieran vida en él; es él quien vive en ellos". ${ }^{51}$ Es como una forma de poseer al otro, bajo el entendido de que al ofrecerle un lugar en la propia lengua, uno se vuelve su habitante y no su dueño, en el sentido de controlarlo, determinando sus intenciones para usarlo con fines utilitarios.

Lo que se nos muestra es que la tentación, al acercarnos al otro, tal vez más que el peligro de morir o volverse loco, implica el riesgo de destruirlo, en el intento de poseerlo -en la soledad propia de nuestra subjetividad-, y quedarse desolado. Que, en toda relación profunda, acecha un carácter destructor, cuya máxima es despejar el horizonte, dejarlo claro; motivado, nos dice Benjamin, por una especie de necesidad de aire fresco y espacio libre, y no por odio. Por ello, quizás, es tan peligroso, pues no es susceptible de sufrir culpa. Su violencia da placer, rejuvenece, simplifica nuestra relación con el pasado y el porvenir. Así, una vez destruido el otro, el destructor no necesita saber

${ }^{50}$ Ibid., p. 82 .

${ }^{51}$ Walter Benjamin, “Unpacking my library”, en Illuminations, op. cit., p. 67. 
con qué sustituirlo; no desea ni comprenderlo, ni ser comprendido. Su ambición es volverlo tan manejable y carente de intenciones propias, hasta desaparecerlo. Por ello, simplemente no está dispuesto a confiar en nada que no sea él mismo: "el carácter destructor es la confiabilidad misma". ${ }^{52}$ Todo el tiempo abre caminos, aunque estén vacíos. En realidad no le importa si alguien puede habitar en ellos o si los puede recorrer en compañía. "El carácter destructor no siente que la vida vale la pena vivirse, sino que el suicidio no vale la pena ser cometido" ${ }^{53} \mathrm{El}$ verdadero peligro de la tentación frente al lenguaje del otro, no es perderse en su otredad, sino destruirla en el logro de una inalienable autonomía. El pensamiento de Benjamin es, por un lado, una advertencia de este peligro, pero por otro, una reflexión sobre las posibilidades de nuestra facultad de representación para acoger al otro y mantener la esperanza.

${ }^{52}$ Walter Benjamin, "Le caractère destructeur", en Euvres, 2000, Paris, Gallimard, vol. II, p. 332.

${ }^{53}$ Ibidem. 
CITAM Derechos Reservados.

La reproducción total o parcial de este artículo se podrá hacer si el ITAM otorga la autorización previamente por escrito. 


\section{ALGUNAS NOTAS SOBRE LA FENOMENOLOGÍA DE LA HISTORIA EN EL PENSAMIENTO DE EDMUND HUSSERL \\ María Dolores Illescas*}

RESUMEN: El efectivo acceso al conocimiento y comprensión de los diversos mundos culturales e históricos supone la constante apertura de un horizonte de co-humanidad y de su necesario correlato, el mundo uno y único, que es el mismo para todos. Esta apertura no puede darse, sino desde el presente, e hincará sus raíces en la constante tensión abierta entre lo actual y lo posible, o con otras palabras, en el abanico de posibilidades preseñaladas en cada caso por el entorno particular en que se vive.

\section{yose \\ REFLECTIONS ON THE PHENOMENOLOGY OF HISTORY IN EDMUND HUSSERL'S THOUGHT}

ABSTRACT: Proper access to knowledge and understanding of different cultural and historical environments supposes a constant opening to a co-humanitarian horizon and its essential cohort, the world, one and unique, but the same for everyone. This opening is only possible in the present harboring its roots in the constant tension between what is current and possible in the range of possibilities available in every situation in the environment in which one lives.

PALABRAS CLAVE: Husserl, fenomenología de la historia, sentido de la historia, multiplicidad de mundos culturales, fenomenología generativa.

KEY WORDS: Husserl, phenomenology of history, meaning of history, multiplicity of cultural worlds, generative phenomenology.

RECEPCIÓN: 9 de junio de 2014.

APROBACIÓN: 10 de noviembre de 2014.

* Facultad de Filosofía y Letras, UNAM/Universidad Iberoamericana. 
CITAM Derechos Reservados.

La reproducción total o parcial de este artículo se podrá hacer si el ITAM otorga la autorización previamente por escrito. 


\section{ALGUNAS NOTAS SOBRE LA FENOMENOLOGÍA DE LA HISTORIA EN EL PENSAMIENTO DE EDMUND HUSSERL}

\section{Introducción}

La experiencia del mundo en que vivimos tiene una estructura específica. Primeramente, se orienta, para cada uno, a partir de él mismo, y en tanto esto ocurre, ofrece al mundo como orientado de "aquí" a "allá", de lo próximo a lo lejano, del propio mundo circundante y familiar a los mundos extraños. Por otra parte, encontramos que la experiencia se halla igualmente orientada en cuanto forma parte de un mundo comunitario y ello por la manera en que, para mí, que soy sujeto de experiencia, los otros sujetos se presentan o me son dados; esto es, de manera mediata para mí (que percibo sus cuerpos vivos y desde esta base apunto certeramente a su vida de conciencia), aunque a la vez de modo inmediato para ellos mismos, o, con otras palabras, por empatía. ${ }^{1}$ Ahora bien, mediante estos otros, así como de su contribución a la formación de nuestro mundo vivido en común,

${ }^{1}$ Edmund Husserl, Zur Phänomenologie der Intersubjektivität (Texte aus dem Nachlass, Dritter Teil 1929-1935. Husserliana XV, Herausgegeben von Iso Kern), 1973, Den Haag, Martinus Nijhoff, p. 220 (en adelante citado como Hua XV). Lo anterior se explica porque la apercepción de sus respectivas vidas de conciencia (una especie de "apuntar a ellas", de captarlas de manera inevitablemente mediata, ya que jamás me serán dadas de manera originaria, como en cambio lo es mi propia vida), exige la base que ofrece la percepción de sus propios cuerpos vivos, de sus movimientos, gestos, posturas, etc., así como de la cualidad expresiva que se manifiesta en ellos, como "índice" certero de esa vida que me resultará siempre otra. A lo anterior ha de añadirse que, de acuerdo con Husserl, la empatía capta no sólo a los 
mis propias experiencias se enriquecen constantemente, se corrigen o complementan su sentido, lo cual ocurre en la medida en que nos referimos a las mismas cosas, como también por cuanto intercambiamos experiencias o transmitimos conocimientos sacados de nuestras respectivas experiencias, etc.

En esto, desde luego, juegan un importante papel las expresiones involuntarias, las que se pueden conocer de los otros por medio de su comportamiento corporal y las que (de manera aperceptiva) les adscribimos, por ejemplo en la captación de sus gestos como expresiones mediatas de su vida y, en ella, de la experiencia que naturalmente las acompaña. ${ }^{2}$ Pero a lo anterior han de añadirse las comunicaciones deliberadas y, en particular, las comunicaciones lingüísticas.

En su desarrollo, en parte activo, en parte pasivo (es decir, no voluntario, que simplemente acontece), la experiencia produce al conocimiento como una adquisición perdurable que permanece disponible en el recuerdo. E igualmente, ella esboza por anticipado lo que en adelante conviene esperar; es captación y aprehensión de lo nuevo según una serie de tipologías familiares que permiten reconocer (o recomprender), en alguna cosa que nos sale al paso, algo en cierto modo ya conocido. La experiencia del mundo es, por lo demás, siempre ya experiencia de la comunidad a la que pertenecemos, cualquiera que sea la extensión de esta experiencia y el sentido ampliado que en el ser unos-con-otros y unos-en-otros recibe el mundo mismo. La edificación orientada del sentido de ser del mundo, en la cual éste posee su acceso tanto como su modo propio de conservar su identidad, a pesar de la aparición de un sentido particular siempre nuevo, posee así una peculiaridad que es propia de cada mundo cultural. ${ }^{3}$

De tal modo, como sujeto de experiencia, tengo un mundo en torno próximo, el mundo familiar en el que soy y me siento "en casa" a partir de mi experiencia propia; se trata del mundo circundante bien conocido, íntimo, que adquiero de manera inmediata u originaria. A este mundo pertenecen también los otros que comparten conmigo el

hombres singulares, sino a comunidades humanas y, asimismo, a todas las configuraciones de la cultura.

${ }^{2}$ Ibid., p. 220.

${ }^{3}$ Ibid., p. 221. 
mismo entorno familiar, esto es, que tienen en el conjunto de experiencias adquiridas la misma cosa a partir de su experiencia propia. Y si bien cada uno posee lo que es para él familiar bajo un modo efectivo y originario, esto no quita que haya efectivas diferencias entre las experiencias de uno y otro, y por tanto, en la ulterior comunitarización de ellas. ${ }^{4}$

Husserl señala que la comunicación más originaria es explicitación (y en el mejor de los casos, expresión lingüística) de aquello de lo que he tenido directamente experiencia y de lo que el otro posee igualmente (en el caso más favorable) en su campo de experiencia, aun si éste no es actualmente presente $;{ }^{5}$ sin embargo, por el camino de la comunicación, también puede tomar parte en una experiencia que no posee de manera original, ganando así una experiencia secundaria (es decir, una experiencia del mismo contenido, aunque obtenida de otro que sí la ha tenido originariamente). Dicha experiencia posee su propio modo de confirmación a partir de la concordancia de la vida comunitaria, en la que se ligan cada experiencia original con las experiencias mediatas o secundarias, como también estas últimas entre ellas por la vía de los distintos tipos de comunicación, todo esto dejando subsistir las concordancias mencionadas en un desarrollo que se mantiene como válido. ${ }^{6}$

Aquel que comprende una comunicación, efectúa de inmediato por su cuenta la experiencia de índole intuitiva que le entrega lo comunicado "como si" fuera el otro, y "como si" él mismo lo viera, validando con ello la perspectiva que él también tendría de encontrarse justamente "allá", en la posición en la que se halla el otro, aunque también es verdad que los enunciados se comprenden, asimismo, de manera no directamente intuitiva, sino vacía (de intuitividad), como significados que no se ven cumplidos o plenificados por la presencia directa de

${ }^{4}$ Más aún, todas las cosas familiares, las que son conocidas e identificadas como tales por quienes comparten la intimidad del mismo entorno, no son verdaderamente tales sin que haya diferencias. Uno las conoce más precisamente, el otro menos, lo que es inevitable dado el "horizonte interno" de toda cosa o, con otras palabras, de su darse necesariamente en forma "perspectiva", por aspectos o perfiles (pero nunca de manera exhaustiva).

${ }^{5}$ Hua XV, p. 222.

${ }^{6}$ Ibid., p. 223. 
la cosa a la que aluden, lo cual ocurre por virtud de una lengua ya formada en relación con el mundo familiar y adaptada a su típica, que perdura de manera relativamente general. ${ }^{7}$ De manera que aquello que vale de manera objetiva para cada uno, puede decirse que vale para todos en la misma comunidad, por cuanto remite de un modo u otro a la fuente última de verdad que es la experiencia original de la cosa, como también, por otro lado, a la experiencia original de los otros.

Es, entonces, en la efectuación de la empatía, ya sea directa o indirecta, donde se confirma de manera continua que nosotros, los que participamos en ella, estamos referidos en nuestro intercambio mutuo al mismo mundo, que formamos parte de la misma humanidad familiar. Esto no excluye las correcciones recíprocas en el caso particular en que tengo que ver con individuos e igualmente donde se trata de las distintas comunidades de personas. ${ }^{8}$

Así pues, el horizonte del mundo se halla siempre en proceso de plenificación por la vía de experiencias que se corrigen y amplían recíprocamente, pero esto ocurre de una manera tal que el mundo guarda siempre una cierta apertura, una indeterminación que puede siempre admitir, aunque a título de esbozo, una nueva determinación experiencial más precisa o diferente.

Ahora bien, el conocimiento histórico se efectúa (no podría ser de otra manera), desde el respectivo presente de conciencia del historiador, como también de su propio mundo de vida, ${ }^{9}$ mundo que es para él efectivamente experimentado y experimentable. Desde aquí llega al preguntar retrospectivo sobre la humanidad pasada (o incluso actual) y el mundo vital que fue (o en su caso es) para estos hombres, precisamente manifestado y válido y por el cual fueron ellos motivados, para luego indagar, también retrospectivamente, acerca de la continuidad de la eficacia histórica del sentido que va pasando de generación en generación hasta llegar a nuestros propios tiempos y ofrecer, así, claves de suma importancia para la comprensión de nuestro propio mundo de cultura.

${ }^{7}$ Ibid.

${ }^{8}$ Ibid., p. 234.

${ }^{9}$ Pues, a fin de cuentas, el presente vivo es el "lugar" de determinación de todo sentido, sea actual o posible. 
Pero hay que advertir de inmediato que el historiador no limita su investigación ingenuamente al interior del mundo histórico que le es previamente dado. Su esfuerzo por hacer comprensible este mundo histórico particular se endereza también a descubrir, conforme a generalidad esencial, lo invariante en él. Puesto que lo singular en cuanto tal es propiamente impensable y por tanto indeterminable, se precisa el recurso a conceptos típicos que, por medio de sus diversos grados de generalidad, al menos apuntan a lo que es verdaderamente universal. ${ }^{10}$

De lo anterior se sigue que, en opinión de Husserl, la praxis propia del oficio de historiador tenga por tarea mostrar una historia universal en su pleno sentido, ya que ésta se extiende por encima de todas las formas del "nosotros", que se ven limitadas de continuo por las historicidades particulares. Mas esto sucede solamente en la forma de un "despertar" (o suscitar) continuamente al horizonte universal como una suerte de "plus ultra". A ello se debe que sea precisamente la humanidad histórica en su comprensión última el verdadero campo de trabajo del historiador y no los meros "hechos pasados". Recordemos aquí, así sea muy brevemente, que a todo yo (y a todo otro) pertenece un "nosotros" siempre abierto, en el sentido de que siempre va unido a él un horizonte de generalidad que tiene, a su vez, sus respectivas gradaciones, de acuerdo con lo que es conocido o desconocido, etc. Pero por ello mismo, sucede que el mundo histórico es para todos uno y el mismo mundo, aunque no sea sino en última instancia. Primero, como mundo circundante propio que no se reconoce como tal

${ }^{10} \mathrm{~A}$ la problemática que atañe a las diversas modalidades (o niveles) en las tipologías y, con ello al tránsito que va de la descripción de las experiencias y representaciones singulares o colectivas vigentes para un determinado grupo o sociedad, a los conceptos que recogen las configuraciones fundamentales de la vida espiritual, ya sea en el nivel de la generalidad empírica, o bien, en el de estructuras esenciales, Husserl dedica una parte significativa de las lecciones sobre Natur und Geist de 1927. Todo ello se encuentra en consonancia con la idea diltheyana de la abstracción de tipos en la historia a fin de salvar el escollo del relativismo. O también con la propuesta teórica de Georg Simmel, en cuanto a la necesidad de analizar la vida e interacción social al recogerla en formas invariables. En todo caso, la noción del "tipo" como una forma de generalidad todavía no conceptual resulta de mucho interés para las llamadas "ciencias del espíritu" debido a su concreción y también a su flexibilidad para guiar a modo de un esquema (que siempre puede modificarse) la integración de una multiplicidad. 
sino al encuentro con aquel otro mundo que le resulta extraño, pero a la postre abiertos ambos a la posibilidad de concordar en un horizonte más amplio que los abraza. ${ }^{11}$ Por eso, el universo de los hechos y procesos históricos que la historiografía tematiza y estudia, conforma nuestro constante horizonte histórico que incluye también lo desconocido o irreconocible que se mantiene, con todo, como accesible a un conocimiento posible. ${ }^{12}$

Así, la ciencia de la historia procede originalmente de la experiencia histórica y sólo es comprensible desde la vida misma, lo cual se deja ver con toda claridad en el hecho de que se expresa sin mayor problema en la lengua general, es decir, mediante un lenguaje que, al hallarse plenamente extendido sobre los cauces de la praxis vital, se adecua excelentemente a lo general y particular de las acciones y trabajos, las metas y finalidades, las pasiones y emociones humanas que en toda su riqueza y variedad estudia el historiador. Para Husserl, de lo que se trata es de mover el conocimiento teorético a la base firme de una observación concreta (aunque universal) de nuestra experiencia y mundo de experiencia, como también del reconocimiento de que, a fin de cuentas, nuestras ciencias todas derivan de uno u otro modo de este mismo mundo directo de la experiencia.

De tal suerte, el método histórico puede entenderse como extensión crítica y metódica de la experiencia natural, precientífica, que gira en torno a la ineludible exigencia de aclarar el propio ser histórico. Su meta consiste en desplegar el horizonte en el que las distintas memorias y tradiciones cobran sentido, llevándonos de tal suerte al ser de la vida pasada, con su respectivo mundo de vida anteriormente experimentado. Desde luego, la conexión con lo que fue vivido y percibido directamente por otros se da mediante de sus manifestaciones indirectas, alcanzando también los recuerdos a ellos comunicados. Y, ulteriormente, a

${ }^{11}$ Ciertamente, tenemos al mundo empírico comunitario como una unidad que incesantemente se va troquelando y corrigiendo de manera relativa, aunque a la vez abierta a lo infinito. Pero lo que sobre todo cabría destacar aquí es precisamente la tendencia a la unidad del ser "uno con otro", la cual, sin embargo, no se encuentra exenta de tensiones y discrepancias. Hua Materialen Band VIII: Späte Texte über Zeitkonstitution (1929-1934). Die C-Manuskripte (Herausgegeben von Dieter Lohmar), 2006, Dordrecht, Springer, p. 20-1.

${ }^{12}$ Hua XXIX, p. 243. 
través de la consideración de aquellas experiencias que fueron compartidas por muchos, así como de sus síntesis, que pueden ser cada vez más amplias. De tal modo, el dominio propio del historiador hinca su raíz en la experiencia y en la extensión de ella, y se despliega al seguir el hilo de las conexiones siempre más plenas y complejas al interior de la experienciabilidad realmente acreditable. Por ello, se dice que su ciencia es puramente descriptiva, aunque también echa mano de procedimientos inductivos que suponen la elaboración de cuidadosas comparaciones. Entonces, el auténtico sentido de la descripción en las llamadas "ciencias del espíritu" en general y de la historia en particular es para Husserl que ésta es descripción (sin menoscabo de un ulterior análisis y contextualización) de lo que fue en su día intuitivamente dado; y dado, a fin de cuentas, como mundo histórico cambiante.

A lo anterior hay que añadir que la ciencia puramente descriptiva es una ciencia que no excede la experiencia (aunque sí la eleva de nivel al tornarla en experiencia comprensora); por tanto, se mantiene en el espacio histórico humano que precisamente quiere conocer y el cual se acredita en experiencias convergentes como "auténtica" experiencia -ganada, en una primera instancia, sólo en tanto realidad relativa, aunque situada, a fin de cuentas, contra el horizonte de un tiempo ensanchado, que es "espacio vital" de la humanidad. ${ }^{13}$

Por contraste tenemos las modernas ciencias matemáticas de la naturaleza, donde, los rendimientos de la física, por ejemplo, se basan en que para ella todos los objetos de la naturaleza se determinan en una absoluta objetividad bajo la idea de un exacto ser "en sí". Y esto se logra mediante conceptos igualmente "exactos", es decir, geométricos o ideales y no ya de tipo empírico. Dichos conceptos proceden, pues, no de una abstracción directa desde la visión realmente experimentada, sino de un peculiar método de pensamiento: la idealización. De ahí que no puedan realmente ser vistos o tocados los puntos matemáticos, las rectas y demás objetos matemáticos que, para una física matemáti-

${ }^{13}$ Edmund Husserl, Die Krisis der Europäischen Wissenschaften und die Transzendentale Phänomenologie. Ergänzungsband (Texte aus dem Nachlass 1934-1937. Husserliana Band XXIX, Herausgegeben von Reinhold N. Smid), 1993, Dordrecht/Boston/London, Kluwer Academic Publishers, p. 313. En adelante citado como Hua XXIX. 
camente exacta, operan como punto de partida para procesos de aprehensión idealizadora. Entre la experiencia y la física descansa la idealización, y cuando la física se dice "ciencia de la experiencia" implica que si el tratamiento sobre la experiencia llega a ser exacto, necesariamente se debe a un manejo idealizador. Pero el problema aquí es, por un lado, el olvido de ese suelo fundante, el de la vida precientífica, desde el cual todos los conceptos científicos, por abstractos que sean, cobran sentido; y, por otra parte, el hecho de que las idealizaciones arriba mencionadas se proyectan en una infinitud que cae cada vez más y más lejos de lo que es efectivamente experimentable. Tales son las conocidas tesis defendidas por Husserl en La crisis de las ciencias europeas y la fenomenología trascendental.

\section{Lo que ha de entenderse por experiencia y mundo de experiencia}

En la experiencia tenemos al mundo, éste aparece. Sólo en tanto es experimentado podemos decir que el mundo existe; y sólo en la experiencia universal e intersubjetiva podemos decir que es válido objetivamente. Es cierto que la experiencia en su modo meramente intuitivo no es (todavía) objetiva en sentido pleno, pero esto no quita que sea el fundamento último incluso del mismo rendimiento cognoscitivo de la ciencia. Y no podría ser, en realidad, de otra manera, pues únicamente mediante la experiencia que de él tenemos, el mundo es lo que es para nosotros y gana un sentido concretamente determinado que, ciertamente, no equivale al de una vacía multiplicidad infinita. El mundo únicamente es tal para nosotros en cuanto pleno de sentido y en ello tiene una estructura mostrable intuitivamente, la que nos ata. ${ }^{14}$

Característica de la postura naturalista es, por contraste, la ceguera para todo lo que queda comprendido bajo el grueso título de la "inten-

${ }^{14}$ Pues no es arbitraria. E. Husserl, Natur und Geist. Vorlesungen Sommersemester 1927, (Husserliana Band XXXII. Herausgegeben von Michael Weiler), 2001, Dordrecht/Boston/ London, Kluwer Academic Publishers, p. 101. En adelante citado como Hua XXXII. 
cionalidad". ${ }^{15}$ Ceguera para la multiplicidad de fenómenos en los cuales, para mí y para todo yo en la "interioridad" de su propia vida psíquica, se da un mundo de experiencia. ${ }^{16}$ Por consiguiente, el pensamiento llega en verdad a carecer de fundamento (bodenlosen) cuando no parte del suelo que ofrece la plenitud de la vida enteramente concreta, con todo lo que ella conlleva, cuando no se sostiene sobre este suelo ni vuelve a él (en una especie de mirada retrospectiva) a fin de esclarecerlo, como ha de ser el caso de todas las abstracciones que derivan (o son sacadas) de dicha fuente.

Toda teoría y toda ciencia corresponde a la vida y se sostiene sobre el mundo preteorético, sobre el mundo de la pura experiencia, aquel en el que vivimos ante todo como hombres prácticos. $\mathrm{O}$, con otras palabras, toda ciencia, con la orientación propia de sus diversas tareas, remite necesariamente a algún modo de la subjetividad, ya que en realidad no puede sino ser relativa a ella. Y la subjetividad, tomada en su plena concreción, se nos ofrece como vida humana en el mundo, pero en un mundo que es, originariamente, intuitivo e histórico. ${ }^{17}$

Hemos de reconocer, entonces, que somos sujetos de un mundo que es siempre para nosotros un universo de realidades a las que, de una $\mathrm{u}$ otra forma, nos dirigimos intencionalmente; a las que, por así decirlo, nos hallamos volcados y que, en tanto tenemos o podemos tener experiencia de ellas, nos conciernen prácticamente, ya sea de manera positiva o negativa.

${ }^{15}$ De una manera muy general, puede caracterizarse la intencionalidad de la conciencia como un "dirigirse a" algo (precisamente aquello de lo que tenemos conciencia), o bien con la muy conocida expresión "toda conciencia es conciencia de..." (aunque el objeto o "contenido" del acto intencional sean, por ejemplo, las propias vivencias).

${ }^{16} \mathrm{Si}$ aplicamos esto al ámbito de lo propiamente histórico, encontraremos una interesante afinidad de la propuesta husserliana con la reflexión historiográfica que Robin G. Collingwood plasmó en los "Epilegómenos" de su famosa Idea de la historia (1985, México, Fondo de Cultura Económica, pp. 201-25). Esto se hace patente cuando el historiador inglés afirma que no existe una distinción entre el proceso o "hecho histórico" ("en sí”), que supuestamente vendría primero, y una manera especial de conocerlo, que vendría después (el pensar histórico); sino que, más radicalmente, el hecho histórico existe y adquiere validez como tal "sólo en y por la mente del historiador".

${ }^{17}$ En efecto, Husserl llega a afirmar con toda claridad que el mundo concreto, el "mundo de la vida" (Lebenswelt) no es otro que el "mundo histórico" mismo (Hua XXIX, p. 426). 
Así, aquello que es para cada uno un mundo existente es, respectivamente, el mundo de experiencia de la percepción actual, del recuerdo, de la pre-visión, con un horizonte de objetos mundanos conocidos aunque no se den (o presenten) actualmente. El término "experiencia" se refiere por tanto, al menos en una primera aproximación, a los modos subjetivos de aparición a los cuales debemos el sentido del mundo. ${ }^{18}$ Pero esto ocurre de un modo tal que en ello vale igualmente para mí y para cada uno, la experiencia de los otros. Mas aún, precisamente por cuanto tengo experiencia del mundo en común con otros, llego a nuestro mundo de experiencia, a nuestros fenómenos de este mundo que es el mismo para todos; llego asimismo a nuestra síntesis en la formación de una comunidad, a nuestros mundos circundantes experimentados en común como idénticos, a sus cambios, con sus unidades sintéticas en la puesta en común de nuestras propias percepciones o recuerdos, etc. ${ }^{19}$

Cada uno de nosotros tiene, pues, su mundo circundante y en comunidad tenemos un mundo en común; toda comunidad particular el suyo. Pero lo importante aquí es que en el cambio incesante al que se encuentran sometidos estos mundos, relativos y diversos, se conserva conscientemente una relación con "el" mundo como una unidad global constantemente presunta (pues no ha de olvidarse que el mundo tiene precisamente la estructura de un horizonte, de un límite que se desplaza). ${ }^{20}$

${ }^{18}$ Hua XV, p. 62.

${ }^{19}$ El concepto de experiencia se refiere, entonces, a lo dado - de manera evidente- en la captación sensible, inmediata, de objetos individuales; sin embargo, este concepto también abarca lo pre-dado pasivo (aquello que siempre hallamos como estando "ya ahí" previamente) y que supone aquella captación para tener lugar (piénsese, por ejemplo, en los datos sensibles o bien en todo lo que hemos vivido y desde los cual enfrentamos lo que es nuevo). En este último nivel de la vida de conciencia, verdaderamente fundamental, tenemos la "doxa" pasiva, pre-dada, como sustrato para las funciones cognoscitivas posibles que opera el sujeto, pero también como sustrato para todas sus valoraciones, planteamientos de metas prácticas y acciones. Véase al respecto, E. Husserl. Experiencia y juicio, 1980, México, UNAM, ed. de Ludwig Landgrebe, trad. de Jas Reuter, pp. 58-9.

${ }^{20}$ Para Husserl, en efecto, el ser del mundo como autocomprensible y permaneciendo igual desde el principio, tiene un carácter presuntivo. ¿Qué quiere decir esto? Para entenderlo, recordemos primeramente la presunción presente en toda experiencia (ya sea real o posible) de algún objeto mundano, de que el "mero lado" en el que lo experimentamos efectivamente, no es el objeto en su pleno ser él mismo. La intención experimentante nos lleva más 
Fijémonos ahora en el nosotros en su vida en comunidad y en tanto vida en el mundo (esto es, a la intersubjetividad como realidad puramente psíquica), así como también a los fenómenos que constituyen (o dan sentido) al mundo y que tienen lugar en esta vida. Al hacer esto encontraremos un tiempo inmanente (o tiempo propio de la vida de conciencia) común para este nosotros: un presente-para-nosotros, un pasadopara-nosotros, un futuro-para-nosotros que de ningún modo se reducen a una mera variante del tiempo del mundo. Cada uno, en la actualidad de su propia vida, encuentra esta intersubjetividad en la coincidencia de su presente con el presente de todo otro, y ello ocurre de tal suerte que en la síntesis propia de la formación de una comunidad, cada quien tiene su presente primordial u originalmente vivido (y en ello su temporalidad inmanente, su tiempo privado, por decirlo así). Pero todos estos presentes primordiales pertenecen al presente constituido intersubjetivamente, ya que ellos son presentes intersubjetivamente a la vez. Además, un mundo familiar (Heimwelt) común se constituye también intersubjetivamente, por virtud de este co-experimentar a la vez un mundo en común.

En lo tocante a la espacialidad, hay que decir que a pesar de no haber ningún "aquí común” que corresponda al "ahora común” a nivel

lejos de lo estrictamente actual a la presunción de lo todavía no experimentado, pero que pertenece al objeto mismo y puede ser captado verdaderamente en percepciones ulteriores, con lo cual una presunción avanza siempre otra vez en el sentido de un plus ultra. Por otra parte, este "siempre de nuevo" atañe también a los otros sujetos en sus respectivas experiencias, en la conexión experiencial de unos con otros respecto de las cosas que son las mismas para todos. En la experiencia aparece que con otros tengo mi objeto, que los otros también pueden recordarlo y volver a él siempre de nuevo e identificarlo de tal modo, e implícitamente con ello se da que lo mismo es perceptible y recordable para nosotros. Sin esto, sin este carácter esencial de ser para todos, no podríamos acceder a ningún objeto como existente; empero, la mera experiencia no da todavía un verdadero mundo (real) existente "en sí". Y, además, el ser del mundo es siempre todavía presuntivo ya que ningún modo del conocimiento del mundo puede estar perfectamente concluido. En cuanto a las presunciones científicas, éstas consistirían en determinados procesos intersubjetivos de creencia en la realidad del mundo presunto, mas precisamente en tanto infinitud por determinar, desde donde se perfila la idea-límite ideal, que es de suyo inalcanzable experiencialmente, de un conocimiento incondicionado (absoluto) cuyo correlato sería el mundo mismo en su pleno ser "en sí" (Hua XXXII, p. 236). 
originario, ${ }^{21}$ la intersubjetividad ha conferido siempre ya una cierta orientación al mundo existente, de manera que toda comunidad en su presente coparticipado tiene su espacio propio: la "residencia" para la familia, el "hábitat" para la ciudad, etc. El mundo aparece así con su forma espacio-temporal propia en los mundos circundantes intersubjetivos. La forma temporal objetiva, bajo la forma del tiempo inmanente intersubjetivo, del tiempo de la vida comunitaria; el espacio objetivo en los modos intersubjetivos de orientación en el espacio. ${ }^{22}$

"Pertenecen", entonces, al horizonte del mundo una forma y una típica universales que me son continuamente pre-indicadas desde mi propio mundo circundante. En las síntesis de identificación en las que cualquier cosa se revela mediante el proceso de su percepción, el cual me la entrega siempre por aspectos o perfiles que la van poniendo cada vez de manifiesto, adquiero al mundo (que es el horizonte "externo" de toda cosa), ${ }^{23}$ como sentido de ser. Lo adquiero con la conciencia de poder determinarlo explicitándolo de maneras muy diferentes y, sin embargo, identificándolo siempre de nuevo. La vía que tomo para identificar al mundo pasa necesariamente por el desvelamiento de otros egos y de su vida asimismo identificadora. ${ }^{24}$

${ }^{21}$ Conviene recordar aquí que el "punto-cero" de la orientación espacial, más aún, la vivencia que "abre" originariamente la dimensión del espacio, que es para cada uno siempre un espacio orientado, la ofrece la vivencia del propio cuerpo. Pero el cuerpo vivo de todo otro es precisamente otro cuerpo vivido originariamente (por él o ella) como propio, vivencia la cual no puedo alcanzar de manera originaria, pero sí aperceptivamente mediante la percepción de sus respectivos cuerpos como objetos del mundo, percepción la cual me remite, dada la expresividad propia de este peculiar "objeto", a la vida psíquica del otro, con lo que se revela la doble dimensión subjetivo-objetiva del cuerpo humano.

${ }^{22}$ Hua XV, p. 67.

${ }^{23}$ En la percepción de toda cosa del mundo se da siempre, junto a lo efectivamente captado de dicho objeto, una cierta anticipación de lo todavía no visto de esa misma cosa (esto es el "horizonte interno" de su determinación progresiva, abierta al infinito). Pero también, por otra parte, este pensamiento que anticipa "va más allá de esta misma cosa con todas sus posibilidades anticipadas [...] hacia otros objetos [que se dan con ella], aun cuando por lo pronto sean conscientes sólo en el trasfondo. Esto significa que toda cosa tiene no sólo un horizonte interno, sino también un horizonte externo, abiertamente ilimitado, de objetos que se dan junto con él' y cuyo plexo total constituye, precisamente, el horizonte del mundo (Experiencia y juicio, op. cit., p. 34).

${ }^{24}$ Hua XV, p. 201. 


\section{La sistemática del ensanchamiento de horizontes en el mundo de la experiencia}

Ahora bien, el mundo, a título de mundo único e idéntico para todos los que vivimos en una comunidad práctica, recibe un contenido siempre nuevo en cuanto mundo presente, en tanto nos es pre-dado. Su unidad es "correlativamente" la unidad de aquellos hombres que se encuentran unos con otros, de manera mediata o inmediata, en una cohesión de experiencia, de valores y finalmente como cohesión práctica, dado que este mundo es para todos ellos (para todos nosotros) un mundo circundante eminentemente práctico.

Por otra parte, este mundo familiar donde nos encontramos siempre ya, tanto como el modo conocido con el que anticipamos alguna cosa que adviene o cambia, tiene también un cierto "estilo" de dación (de ponerse de manifiesto) justo como mundo de nuestra experiencia. Y a este estilo pertenece igualmente la indeterminación de todo aquello que se halla implicado en dicho mundo, que afirmamos sin más como existente. ${ }^{25}$

Tocante a lo que cada vez es experimentado a partir de este mundo, sabemos qué estilo tendrá; conocemos el carácter típico de su finitud relativa, de lo que se puede abarcar de una mirada y en cierta forma ya conocemos, de aquello que está ahí para nosotros y que recibe nuevas formas en el marco de los caracteres típicos familiares. Nuestros tipos familiares desempeñan así el papel justamente de una tipicidad que nos permite registrar en objetos no típicos semejanzas en ellos y así comprenderlos o recomprenderlos. "Porque siempre proporcionan un mínimo 'núcleo de cognoscibilidad' que nos permite, aun cuando tratamos con objetos muy extraños, intentar la necesaria trasposición respecto del sentido de los objetos ya conocidos". ${ }^{26}$ Dicha tipicidad nos provee de un horizonte familiar de posible explicitación que mediatiza nuestras intuiciones, como también los efectos que podemos recibir, tanto de la acción de otros sujetos, como de objetos culturales. ${ }^{27}$

${ }^{25}$ Ibid., pp. 197-8.

${ }^{26}$ Roberto Walton, "Transmisión de sentido y nexo de eficacia" en Escritos de filosofía, núm. 43, 2003, p. 373.

${ }^{27}$ Ibid. 
Lo que hay que subrayar aquí es que el mundo siempre llega más lejos que nuestra experiencia presente; en tanto multiplicidad finita, es siempre un mundo conocido, pero también un mundo que se ensancha en la extensión de la experiencia que vamos adquiriendo de él y que siempre permanece susceptible de irse ampliando más. Para ello puedo recurrir a los otros, puedo interrogar a quienes me son cercanos a propósito de su mundo circundante (este mundo que para mí es indeterminado en tanto es el mundo que ellos han experimentado, pero que permanece para mí desconocido en sus particularidades, etc.). En todo lo cual ocurre que incluso el estilo -como estilo de ampliación del conocimiento-, se anticipa en lo tocante a las esferas mundanas desconocidas; se anticipa justamente como un estilo reiterable.

Más aún, en su horizonte reiterable de futuro, el mundo es reiterable igualmente bajo la forma de una ampliación que debe continuar. Esta potencialidad pertenece también a nuestro pasado, puesto que siempre hubiéramos podido aprender a conocer nuevas cosas y en tal dirección más bien que en tal otra, de la misma manera que ahora mismo la prosecución de su ensanchamiento tiene abierto un abanico de posibilidades y direcciones diversas. ${ }^{28}$ Así, el mundo se temporaliza en el flujo de la temporalización subjetiva e intersubjetiva, pero la potencialidad inherente a la intersubjetividad de ampliar su conocimiento en un sistema fundado lleva en sí el carácter de ser una potencialidad reiterable; de tal modo, el mundo se expande y nuevas cosas que en absoluto estaban allí llegan a ser tomadas en consideración. Por otra parte, además de la tipicidad en la edificación de cada mundo circundante relativo en su infinidad abierta propia, cada uno de dichos mundos posee su propio estilo de lo lejano, indicando de manera indeterminada proximidades que, al menos por el momento, permanecen inaccesibles. ${ }^{29}$

Cada mundo familiar posee, por tanto, una apertura propia por la cual su conservación continúa manteniendo su identidad como tal mundo

${ }^{28}$ Hua XV, p. 199.

${ }^{29}$ Ibid., pp. 219-20. En este sentido, "la cercanía prescribe ciertamente el estilo de lo lejano" (Hua XXXII, p. 116). 
familiar, precisamente, y su extensión espacio-temporal aparece posible. A este mundo pertenecen también otros sujetos que nos son muy próximos y tienen las mismas cosas que nosotros a partir de su propia experiencia. E igualmente se incluye allí el intercambio inmediato de experiencia en el que nace el entorno familiar común, pero ahora en un sentido ampliado.

\section{El encadenamiento generativo y su "infinitud"}

A la formación del sentido del mundo objetivo, por cuanto se dice de él que es "infinito", pertenece la obra y acción de la intersubjetividad generativa (es decir, aquella que da lugar a la liga y sucesión de las generaciones), puesto que cada uno de nosotros debe ampliar este mundo en su temporalización finita, aun si es solamente de manera finita; en efecto, el encadenamiento de las generaciones entre sujetos se halla constituido, para cada uno, reiterativamente a partir de la finitud. Y la vida y su temporalización se cumplen en una presunción continua que se reitera, a saber, la presunción de que aquellos que son otros para mí, tienen el mismo mundo en torno finito que yo y además un mundo circundante que yo no tengo todavía o que no tengo en absoluto y no puedo tener fácticamente; o bien, que mis otros tienen, a su vez, sus otros y éstos últimos sus respectivos otros, etc., y en esta serie de mediaciones, gente que llegue a serme fácticamente inaccesible. ${ }^{30}$

Con todo, siempre espero poder relacionarme con quienes no conozco todavía y tengo experiencia de los otros como detentando estas mismas posibilidades. Lo cual se hace, por lo demás, en un encadenamiento generativo, por lo que el mundo en su temporalidad sucesiva va explicitando su validez de ser en el encadenamiento abierto de la comunicación; desde luego, con esto se funda también la posibilidad de comprender el mundo como un mundo de la vida de generaciones que se suceden unas a otras en la unidad de una tradición histórica, luego, como un mundo cultural histórico; y enseguida tendríamos

\footnotetext{
${ }^{30}$ Hua XV, p. 199-200.
} 
la posibilidad de explicar el mundo y la humanidad en una temporalidad abierta.

Sin duda, en el proceso de ir desplazando los límites de nuestro mundo, tiene una importancia fundamental el encuentro con los extraños y su respectivo mundo de vida, que es también un mundo familiar, pero ciertamente otro diferente del propio. Mas, ¿qué ocurre con "el” mundo que, como hemos visto, no nos es dado sino de manera "fragmentaria", como un mundo de la vida meramente finito? El mundo que existe para nosotros es siempre, en tanto horizonte, mundo de una experiencia posible; pero esta posibilidad, ¿no quiere decir ante todo un acceso potencial (luego una verificación) en términos de tiempo y espacio? En lo tocante a la temporalidad, tenemos la generación -mis padres, nuestros padres, los padres de mis padres, etc.-, es decir, un pasado pre-indicado como aquél de los mundos circundantes que pertenecieron a nuestros antepasados, pero que valen para nosotros, por poco conocidos o indeterminados que sean, en la anticipación que podemos hacer de ellos y su posible conocimiento, con lo cual se forma el horizonte abierto de lo que puede anunciarse históricamente. ${ }^{31}$

Es claro que en todo esto tenemos una limitación general que vale de antemano, y es el hecho de que en este mundo del nacimiento y la muerte tengo una vida temporalmente finita y fuerzas finitas, aunque siempre en desarrollo; en este marco, encuentro que tengo un cierto dominio de lo lejano más externo, que existe para mí al mismo tiempo que para aquellos que comparten mi mundo familiar. Alcanzar este dominio de lo lejano no se da, empero, sin producir de nuevo las apariciones propias de otro dominio de lo lejano. Pero estas apariciones no indicarán ya objetos de una experiencia fácticamente posible (vermöglich); en otros términos, estos objetos no podrán ser ya pre-indicados por estas potencialidades fácticas como existiendo efectivamente; así ocurre para todos nosotros, aunque viajemos y ensanchemos con ello nuestro mundo. En todo caso, el mundo permanece como el mundo de tal potencialidad de la experiencia, pero sobre todo como aquel que, a partir de allí, es para nosotros siempre en la finitud.

${ }^{31}$ Ibid., p. 206. 


\section{Devenir y síntesis de mundos circundantes}

Es importante notar en este punto que la síntesis de los diversos mundos de la vida, tanto como de las generaciones que se suceden, no produce, como parecía en una primera aproximación, un mundo verdaderamente infinito como "mundo de una experiencia posible", entendiendo por esto el universo de los entes que la humanidad, en una comunicación universal y en tanto generativa (es decir, que comprende los lazos entre diversas generaciones), con su tiempo histórico, pudiera efectivamente experimentar ad infinitum todas las ampliaciones potenciales de su entorno; el sentido mismo de ser del mundo se halla fundado, ciertamente, sobre el sentido "otro trascendental" (esto es, constituyente de sentido), pero de un modo tal que conduce siempre de nuevo a una esfera mundana finita. ${ }^{32}$ Lo anterior implica, claro está, la dinámica de la ampliación del mundo familiar y en ello la aparición, al menos presuntivamente, de cada vez otros y nuevos otros sujetos por venir... Y también, por otra parte, que el mundo valdría siempre para todos los nuevos sujetos, aunque eventualmente se le tuvieran que hacer correcciones a la serie de determinaciones que sobre él se hubieran ya ganado.

¿Cómo opera este proceso de una constitución progresiva del mundo, de una formación progresiva de lo propio y lo extraño con sus mundos circundantes que cambian en este proceso y que son para sí en tanto valen para sus respectivos sujetos como mundos vivos, que reciben de estas personalidades una forma siempre nueva, un sentido teleológico o afectivo siempre nuevo? ¿Cómo ocurre que a partir de mí -y de nosotros- se constituye una pluralidad de "humanidades" como pueblos, que con toda su irreductible diversidad, forman sin embargo una humanidad única?

Cada una de estas "humanidades" en plural tiene como mundo circundante simplemente un mundo, pero un mundo que tiene su concordancia propia. En el carácter universal de la realidad, éste no es, sin embargo, un mundo concordante de antemano con el que vale para

${ }^{32}$ Ibid., p, 207. 
otros grupos humanos, para otras culturas o sociedades. ${ }^{33}$ Lo que en todo caso permanece como constantemente común es la estructura natural con su humanidad, que debe entenderse en el sentido más universal; esto no quiere decir que para mí y para nosotros en nuestro grupo familiar, como también para todo otro, el respectivo mundo cultural se halle pre-levantado sobre una naturaleza universal pura. ${ }^{34}$

Pero, entonces, ¿qué es aquello que permanece válido para mí, en vista de la discordancia que existe entre mi (o "nuestra") experiencia y la de otros grupos humanos? Hasta aquí, señala Husserl, hemos aceptado como estados de hecho en el mundo a las sociedades y culturas extrañas. Mas en esto no ha habido síntesis, en el sentido de que nuestro mundo circundante simplemente incorporara lo que para los extraños es válido. Mi mundo "ampliado" no se ha constituido de un modo tal que fuera simplemente una amalgama de mi mundo con los otros mundos, formando todos ellos una unidad extraída de la convicción en la experiencia concordante, que sería propia de todos los hombres de tal círculo ampliado. ${ }^{35}$

El mundo que vale para mí y para nosotros a partir de la concordancia de nuestra experiencia tiene un horizonte espacio-temporal, el horizonte posible del ser real; sin embargo, este ser no debe, como hasta el presente, ser anticipado solamente bajo la forma de una continuación abierta en el estilo que ha prevalecido hasta ahora, es decir, en una experiencia efectivamente posible. En tal experiencia, los hombres en general se anticipan o aperciben siempre como hombres que pertenecen a mi tipo de humanidad, con lo que "el" mundo recibe demasiado pronto la forma de $m i$ mundo en torno propio, el que me es familiar. Empero, en cuanto recibe una determinación diferente, el horizonte espacio-temporal real y abierto se reconoce como ocupado por un pueblo extraño con su mundo circundante extraño, distinto del mío,

${ }^{33}$ Ibid., p. 216.

${ }^{34} \mathrm{Sin}$ duda, estas diferentes humanidades pertenecen a un solo y mismo mundo que es en primera instancia el mundo para todas ellas. Pero esto ocurre ante todo bajo el modo de un mundo de realidades que se prosigue y continúa prosiguiéndose con un "nosotros" siempre nuevo y siempre con nuevos "nuestros mundos".

${ }^{35}$ Hua XV, p. 216. 
por donde se distinguen luego el mundo real en general y el mundo circundante, que pertenece a un pueblo determinado.

Lo que hay que tener muy claro es que el horizonte de ser para los otros es solamente conocido bajo la forma del dominio extraño y de la comprensibilidad (no siempre fácil) de su mundo en torno. Mundo que se halla solamente indicado y que sólo puede explicitarse de manera indirecta a partir de aquello que se puede comprender de la forma más general de su cultura. ${ }^{36}$

Atendiendo a lo anterior, ¿cómo puede hablarse de un mundo de experiencia que vale para todos los hombres en general, ya sean conocidos o desconocidos? Al aprender a conocer, por una empatía bien lograda, ${ }^{37}$ aquello que me resulta extraño en un pueblo y en su mundo circundante, llego a un mundo de estados de hecho ampliados. Y el mundo de estados es cada vez diferente para los distintos círculos de personas al interior de un pueblo; esto ocurre de tal manera que cada uno sabe, al unísono con todos los demás, que tiene experiencia de un solo y mismo mundo, aunque cada grupo humano particular lo aprehenda de manera diferente. ${ }^{38}$

¿Cuál es la base de esta mismidad? ¿Cuál la experiencia universal concordante a la que corresponde un mundo auténticamente universal? Sin duda poseemos el mundo abierto sin fin tras sus realidades efectivas conocidas y sus posibilidades desconocidas, cada uno a partir de sí, y también por la vía de las comunicaciones cuyas redes soportan la comunidad humana de experiencia. Nuestro mundo circundante, aquel que se liga a nosotros de manera histórica a partir de nuestros respectivos presentes, el mundo progresivamente accesible, posee el horizonte abierto de una naturaleza tal que trasciende la naturaleza que pertenece a este círculo y nos es efectivamente accesible.

Con todo, conviene recordar aquí que no poseemos el mundo, sino en el modo del horizonte y en realidad no poseemos todos los mismos hechos efectivamente dados, sino sólo como posibilidades abiertas. Así,

${ }^{36} \mathrm{Ibid}$, p. 217.

${ }^{37}$ Aunque ha de aclararse en seguida que ésta seguirá siendo siempre limitada.

${ }^{38}$ Hua XV, p. 217. 
estamos lejos de poder tener experiencia en algún momento ulterior, de manera fáctica, de todo aquello que otro hombre vive en sí como hombre fáctico; tampoco cabe duda de que no todos los hechos nos son accesibles en el ejercicio de nuestros poderes efectivos. ${ }^{39}$

Por lo demás, el mundo no es el único horizonte general con el que nos encontramos, sino que las realidades individuales de las que ya tenemos experiencia tienen sus horizontes internos (pues se nos dan sólo perspectivamente) y dichos horizontes no son de ningún modo perfectamente accesibles, y lo mismo aunque el mundo de la experiencia sea un universo abierto de realidades concretas que podemos percibir, recordar, etc. En esta medida, tenemos todos un cierto acceso (al menos de manera indirecta y por mediación de los otros con quienes entramos en contacto), a todas las realidades a las cuales ellos tienen acceso también, como objetos idénticos de una experiencia posible, sigue siendo verdad que ni ellos ni nosotros tenemos acceso a todos los rasgos objetivos de dichas realidades. ${ }^{40}$

Ahora bien, eso que yo aprendo a conocer en mi experiencia concordante por cuanto ella determina para mí un mundo ya válido, eso mismo concierne al mundo del que otro tiene también experiencia, puesto que él es reconocido por mí como referido al mismo mundo. Yo no tengo experiencia de este otro sino en tanto él experimenta todo aquello de lo que yo tengo o puedo tener experiencia, de manera que un suelo de comunidad efectiva por empatía se da como dominio de accesibilidades efectivas comunes. Tenemos experiencia, pues, del mismo ámbito de realidades $\mathrm{y}$, en particular, compartimos la experiencia de lo real que nos concierne. Que el otro no posea ciertas experiencias y que de hecho no pueda en absoluto poseerlas no perturba la concordancia intersubjetiva de nuestro mundo común. ${ }^{41}$

Comprender al extraño como sujeto de su mundo familiar y ligado a su grupo de pertenencia por una comunidad concordante de experiencia; apercibirlo así, es una experiencia con un horizonte todavía muy inde-

${ }^{39}$ Ibid., pp. 228-9.

${ }^{40}$ Ibid., p. 229.

${ }^{41}$ Ibid., p. 230. 
terminado. Pertenece a la experiencia efectiva del otro y a su comprensión explícita, a la producción completa de una comunidad de experiencia con él, aprender a conocer su mundo familiar que es para él cada vez presente y con ello el grupo humano que le es asimismo familiar; esto es, su acción efectiva, su creación en su mundo circundante, la forma en que este mundo familiar ha recibido y continúa recibiendo su sentido. El problema radica en saber hasta qué punto puedo adoptar por mi cuenta las vigencias de experiencia de los otros, de los extraños, para luego proceder a una síntesis de su mundo familiar con el mío. ${ }^{42}$

Ciertamente, y debido al elevado nivel de generalidad en el que se pone en juego la tipicidad del horizonte familiar, las analogías que desde él se articulan prefiguran posibles líneas para un conocimiento más preciso que, por medio de un permanente proceso de corrección, puede avanzar hacia ulteriores determinaciones o incluso hacia modos distintos de determinación. Pero, ¿es el mundo una mera síntesis progresiva de finitudes históricas?

La cuestión aquí no sería, desde luego, la de saber quién, en su inmanencia de experiencia, tiene la precedencia, sino lo que hay tocante a la comunidad de experiencias de los dos lados en su síntesis de concordancia, posible o por producir. Si ella se produce, e incluso en síntesis con grupos humanos siempre nuevos, siempre se puede todavía preguntar por el carácter definitivo de esta concordancia o, más bien, reconocer que dicha concordancia es siempre de nuevo relativa y en movimiento. Al comprender las experiencias y las concordancias de los otros, teniendo a la vista no ya al mundo como mundo de mis convicciones privadas, sino al mundo para todos, las dejo valer en tanto ellas co-constituyen mi mundo. Esto implica tener en cuenta a los otros como susceptibles de co-validar mis propias vigencias de experiencia; con ello gano la posibilidad de circunscribir un mundo posible de experiencia, como mundo circundante de mis semejantes que se mantienen en la unidad de una comunidad de experiencia, pero también una humanidad en general, es decir, en la infinidad abierta. ${ }^{43}$

${ }^{42}$ Hua XV, p. 233.

${ }^{43}$ Ibid., p. 234. 
Demos ahora el "salto" al nivel trascendental, dejando así el nivel de los meros hechos, para preguntar: ¿cómo se pueden llevar las experiencias y concordancias de experiencia de todos los co-sujetos trascendentales (o dadores de sentido), a una concordancia que habría de proseguir indefinidamente, en la cohesión posible de todas ellas? ¿Cuál sería, pues, la forma esencial de una concordancia absoluta de la experiencia intersubjetiva que se extiende al infinito, a través de los mundos familiares y culturales relativos y sus síntesis?

\section{Caminos abiertos}

Se abren aquí dos posibles vías para continuar la indagación que se ha venido bosquejando:

1) Respecto de la naturaleza infinita que se extiende más allá de la naturaleza efectivamente accesible que pertenece a cada mundo circundante, es posible afirmar que poseemos, en efecto, tal naturaleza "infinita", pero como la idea de una "verdad en sí" por alcanzar. ${ }^{44}$ Con ello se tiene la meta que orienta los esfuerzos de la ciencia natural. ${ }^{45}$ 2) En lo tocante al mundo uno y único, considerado esta vez como correlato de un "nosotros" universal que enmarcaría las diversas comunidades históricas particulares, tenemos que se articula sobre todo por virtud de una forma final que, al interior de una estructura universal de horizonte, no permite más que una determinación por aproximación. En dicha teleología tendríamos, por tanto, el sentido unificador de la pluralidad de historias particulares y sus respectivas vigencias, pero como tarea por realizar. Tarea de índole eminentemente ética: a saber, la de un proceso, por otra parte siempre amenazado, de humanización del mundo. Este proceso unificador de la historia es, ante todo, un constante advenimiento de sentido.

${ }^{44}$ Para Husserl, en efecto, la verdadera naturaleza como unidad sintética de todas las experiencias de la humanidad es una idea que, precisamente, guía la ciencia de las "idealizaciones", siendo éstas fundamentalmente de índole matemática (Hua XXXII, p. 73).

${ }^{45}$ En vista de lo anterior, también cabe formular el problema que aquí nos ocupa en términos de la coexistencia, o de la posibilidad de una infinidad de mundos familiares en conexión mediata, en relación con el problema de la constitución de una tal naturaleza infinita. 
Quisiera añadir a lo anterior que la descripción del mundo circundante intuitivo, de suyo concreto, fáctico y singular, da lugar a la formación de "conceptos de experiencia" o tipificaciones empíricas. Más aún, la generalidad que ganamos gracias al conocimiento del entorno individual concreto no es menos individual que aquella de los objetos singulares descritos en sus particularidades. Ya cuando en la vida práctica avanzamos de experiencia en experiencia, de un objeto singular a otro, nos vemos empujados a la generalidad y, querámoslo o no, cuando una nueva singularidad se nos presenta, la experimentamos en su tipo individual. ${ }^{46}$ Lo general descansa, así, en la forma de apercepciones típicas, levantadas sobre la individualidad determinada del mundo circundante en que vivimos; por eso, esta generalidad puede decirse con todo derecho individual, por cuanto se sostiene sobre tal entorno concreto.

Ahora bien, las ciencias culturales o históricas son todas ellas ciencias del mundo circundante y se sostienen en el marco de la accesibilidad concreta-intuitiva, directa o indirecta, del mundo que es, en cada caso, el escenario para la praxis humana. Ciertamente, el mundo fáctico individual tiene sus respectivas estructuras, y las tiene con necesidad esencial, pero ellas le pertenecen sobre todo en cuanto unidas a un mundo posible, por lo que estas estructuras necesarias ya no se hallan especialmente ligadas al factum particular que llamamos mundo circundante intuitivo; de ahí la distinción ulterior entre mundo circundante (Umwelt) y mundo en sentido pleno (Welt), que señala una estructura apriórica general fundada en la esencia de una posible experiencia y mundo de experiencia, pero al llegar a este último punto, nos salimos de la esfera propia de las ciencias de la cultura.

Consideremos ahora, de nueva cuenta, el mundo de experiencia logrado por una comunidad de diversos sujetos y ordenado como el mundo de sus concreciones intuitivas reales y posibles. Las estructuras presuntivas más amplias de dicho mundo, aquellas que pertenecerían al mundo tomado en sentido pleno, quedan todavía por alcanzar, aunque valen ya como existentes. Y, sin embargo, con ello tenemos también el índice que apunta a una absoluta intersubjetividad idéntica como correlato de un mundo que es, a fin de cuentas, el mismo para todos.

${ }^{46}$ Ibid., p. 200. 
CITAM Derechos Reservados.

La reproducción total o parcial de este artículo se podrá hacer si el ITAM otorga la autorización previamente por escrito. 


\title{
LA ESCALERA DE WITTGENSTEIN
}

\author{
Javier García-Salcedo*
}

RESUMEN: En este trabajo se exponen las principales tesis metafísicas y semánticas que Wittgenstein desarrolla en el Tractatus Logico-Philosophicus; algunos problemas interpretativos clásicos se abordan y resuelven. En la última sección, se considera el impacto que las tesis expuestas tienen sobre el propósito último del Tractatus, así como la concepción de la filosofía que de ellas se desgrana.

$$
\text { rose }
$$

\section{WITTGENSTEIN'S LADDER}

ABSTRACT: In this article, we will present the main metaphysical and semantic topics in Wittgenstein's Tractatus Logico-Philosophicus while addressing and solving some of its classical interpretation issues. Finally, we will ponder the impact of these theories on Tractatus' objective as well as on the conception of philosophy they originate.

PALABRAS ClAVE: Wittgenstein, Tractatus Logico-Philosophicus, metafísica, semántica, lógica. KEY WORDS: Wittgenstein, Tractatus Logico-Philosophicus, metaphysics, semantics, logic.

RECEPCIÓN: 5 de agosto de 2014.

APROBACIÓN: 26 de noviembre de 2014.

* Facultad de Filosofía y Letras, UNAM. 
CITAM Derechos Reservados.

La reproducción total o parcial de este artículo se podrá hacer si el ITAM otorga la autorización previamente por escrito. 


\section{LA ESCALERA DE WITTGENSTEIN*}

\section{Metafísica del Tractatus}

\section{El lenguaje es, en un sentido muy} amplio, un instrumento que los seres humanos empleamos para poder llevar a cabo ciertas cosas útiles en nuestra vida. Una de estas cosas consiste en describir el mundo, en representar, por el intermedio de signos (mentales, acústicos, gráficos, etc.), la multiplicidad de lo que ocurre. Esta característica del lenguaje es tan fecunda que podríamos llegar a pensar, como Wittgenstein lo hizo mientras redactaba el Tractatus (de aquí en adelante 'TLP'), que describir el mundo, o lo que según él es equivalente, decir verdades (o pensarlas, creerlas, comunicarlas), es el propósito primordial del uso del lenguaje; sin embargo, diciendo esto todavía no habríamos terminado de precisar el sentido en el cual el español, por ejemplo, es una herramienta. Pues una herramienta supone, además de un propósito, un modo de empleo o de aplicación que garantice que, si ciertas condiciones son satisfechas, ciertos resultados son obtenidos. Por tanto, si realmente el lenguaje es un instrumento para describir el mundo, parece que deberían poderse formular las condiciones cuya satisfacción nos permita generar secuencias de signos aptas para la verdad. ¿Cuáles son estas condiciones?

*Agradezco el apoyo del proyecto CONACYT CCB 2011166502, “Aspectos filosóficos de la modalidad", invaluable para la realización de este trabajo. 
Intuitivamente, podríamos decir que el propósito central de Wittgenstein en el TLP consiste en responder a esta pregunta, que llamaremos la "Cuestión crucial (del TLP)", desde el punto de vista más general posible: el de la lógica. No obstante, en la medida en que, según el TLP, cualquier lenguaje debe permitir la expresión de verdades, y que expresar una verdad consiste en representar o figurar adecuadamente algún aspecto del mundo, la tarea de resolver la cuestión crucial depende, en parte, de un factor extra-lingüístico: de cuáles y cómo sean esos aspectos del mundo que nos es posible capturar mediante el lenguaje. Por esta razón, y como requisito previo a una investigación propiamente lógicolingüística, el TLP lleva a cabo una indagación de orden metafísico para esclarecer la constitución del objeto de la representación lingüística, para elucidar qué es aquello que del mundo es susceptible de ser puesto en palabras. ${ }^{1}$ En esta sección pasaremos revista a los resultados de tal indagación y ofreceremos una propuesta de solución a uno de los problemas interpretativos más salientes de la metafísica desarrollada en el TLP.

\subsection{Mundo, hechos y objetos. Forma de los objetos}

Wittgenstein busca calificar la noción de "mundo" desde los aforismos inaugurales del TLP. Algunos de ellos son los siguientes:

1. El mundo es todo lo que es el caso.

1.1 El mundo es la totalidad de los hechos, no de las cosas.

1.11 El mundo está determinado por los hechos y por ser todos los hechos.

${ }^{1}$ Aquí surge la siguiente cuestión: para lograr este propósito (determinar los aspectos metafísicos que condicionan la confección de cualquier lenguaje posible), parecemos requerir ya de un lenguaje -en nuestro caso, del lenguaje del TLP. Pero si esto es el caso, y si el lenguaje del TLP es genuinamente un lenguaje, ¿son los aspectos metafísicos que el TLP formula idénticos a los rasgos metafísicos que condicionan la confección del lenguaje del TLP? Haré honor a esta preocupación luego de un largo trecho, en la sub-sección 2.2. 


\subsection{El mundo se divide en hechos ${ }^{2}$}

El mundo, en el contexto del TLP, es concebido como una entidad compleja, susceptible de ser descompuesta en hechos constitutivos. Esto implica, en particular, que el mundo no es analizable en términos de objetos constitutivos ( $\$ 1.1)$. Esta idea es bastante intuitiva; después de todo, para saber qué es el mundo necesitamos describirlo, y parece claro que es algo que ninguna lista de nombres, a diferencia de una lista de proposiciones o enunciados, es capaz de hacer. ${ }^{3}$ Pero usamos nombres para referirnos a objetos y proposiciones para hablar de lo que acaece; por esa razón, resulta natural pensar que el mundo debe estar constituido primordialmente por aquello que nuestras proposiciones representan, es decir, por hechos o sucesos, y no por aquello que los nombres denotan. Por supuesto, en la medida en que los objetos son los constituyentes de lo que en el siguiente párrafo llamaremos hechos atómicos (o estados de cosas), el TLP supone una relación muy importante entre los objetos y el mundo. Pero acerca de esta relación nos extenderemos más adelante; ${ }^{4}$ por el momento basta con decir que ésta no es una de identidad.

Los hechos forman parte del mundo en el mismo sentido en que un objeto forma parte de él: son entidades à part entière, metafísicamente irreductibles a cualquier otro tipo de entidad. Ahora bien, en el contexto del TLP los hechos admiten al menos dos tipos de distinciones. La primera de ellas, que atañe a su complejidad tanto como a su fundamentalidad, segrega los hechos moleculares y los hechos atómicos. Como su nombre sugiere, los hechos moleculares se caracterizan por estar compuestos de hechos de un nivel de complejidad inferior, pero esto no significa que los moleculares constituyan un tipo de hecho "por

\footnotetext{
${ }^{2}$ A lo largo de este artículo haré referencia a la versión castellana del Tractatus LogicoPhilosophicus de Wittgenstein (2002, Madrid, Tecnos, traducción, introducción y notas de L. M. Valdés Villanueva).

${ }^{3}$ Como veremos más adelante (sección 2), las proposiciones tractarianas son figuras, las figuras son hechos y todos los hechos son susceptibles de ser descritos y estudiados por las ciencias empíricas. Por tanto, Wittgenstein no está casado, al hablar de proposiciones, con una ontología de objetos abstractos.

${ }^{4}$ Los impacientes pueden consultar el final de esta sub-sección y la sub-sección 1.2.
} 
encima" de los sucesos más simples que se articulan en su seno. Un hecho molecular no supone nada más del mundo que lo que suponen los hechos de carácter más simple que lo conforman. Dicho en otras palabras, la diferencia que hace un hecho molecular en el mundo es una función de la diferencia que hace cada uno de los hechos que agrupa. En este orden de ideas, un hecho como, por ejemplo, NAPOLEÓN BONAPARTE FUE DERROTADO EN WATERLOO POR ARTHUR WELLESLEY Y GEBHARDT LEBERECHT VON BLÜCHER ${ }^{5}$ debe ser considerado, según el TLP, como un hecho molecular que aglomera tres hechos de mayor simplicidad, a saber, los hechos NAPOLEÓN BONAPARTE FUE DERROTADO EN WATERLOO; NAPOLEÓN BONAPARTE FUE DERROTADO POR Arthur Wellesley; y Napoleón Bonaparte fue derrotado POR GEBHARDT LEBERECHT VON BLÜCHER. Claramente, todo lo que precisa NAPOLEÓN BONAPARTE FUE DERROTADO EN WATERLOO POR ARTHUR WELLESLEY Y GEBHARDT LEBERECHT VON BLÜCHER para acaecer es que los tres hechos que lo componen sean (todos) el caso, e inversamente: todo lo que requiere NAPOLEÓN BONAPARTE FUE DERROTADO EN WATERLOO POR ARTHUR WELLESLEY Y GEBHARDT LEBERECHT VON BLÜCHER para no ser el caso es que alguno de los hechos que lo constituyen no acaezca. Por consiguiente, podemos afirmar que, en el contexto del TLP, existe una relación inversa entre la complejidad y la fundamentalidad metafísicas de los hechos, y que la existencia de esta relación explica por qué no sería adecuado considerar a un hecho molecular como una entidad extra, por encima de los hechos menos complejos de los que se encuentra conformado.

La imagen cosmológica que se desgrana de las primeras secciones del TLP es la siguiente. El mundo, entidad compleja par excellence, es susceptible de ser analizado en términos de hechos moleculares constitutivos. Éstos, a su vez, se encuentran compuestos por hechos de un nivel de complejidad inferior, de cuya descomposición puede surgir una colección de hechos todavía más simples y aptos para recibir el mismo tipo de análisis. No obstante, pese a poder ser iterado en principio un

${ }^{5}$ En lo sucesivo me referiré a los hechos por medio de oraciones escritas con VERSALES a fin de distinguirlos de las oraciones que usamos para referirnos a ellos. 
gran número de veces, este proceso de descomposición no se prolonga indefinidamente; en algún punto, el análisis del mundo no arroja ninguna clase de hechos, sino una colección de entidades pertenecientes a una categoría ontológica diferente: la de los objetos. Por tanto, en el penúltimo estadio de análisis hallaremos la clase de hechos más simple y más fundamental posible: la clase de los denominados "estados de cosas" o "hechos atómicos". Wittgenstein afirma:

2 Lo que es el caso, el hecho, es la existencia de estados de cosas. ${ }^{6}$

2.01 Un estado de cosas es una combinación de objetos (cosas).

2.02 Los objetos son simples.

A modo de ilustración, podríamos considerar que SCHOPENHAUER ES UN SER HUMANO es una instancia de la clase de los hechos atómicos ya que, en contraste con NAPOLEÓN BONAPARTE FUE DERROTADO EN WATERLOO POR ARTHUR WELLESLEY Y GEBHARDT LEBERECHT VON BLÜCHER, SCHOPENHAUER ES UN SER HUMANO está constituido por entidades que se resisten al tipo de análisis emprendido por el TLP: Schopenhauer, por un lado, y la humanidad, por el otro. ${ }^{7}$ Esto, dicho sea de paso, indica que una característica definitoria de los hechos es la de ser, a diferencia de los objetos, entidades articuladas o estructuradas. La estructura de un hecho atómico se encuentra determinada por el modo en que los objetos que lo componen están mutuamente conectados; en lo que concierne a los hechos moleculares, por la manera en que los hechos más simples que lo constituyen se relacionan entre sí (§2.01,

${ }^{6}$ Este aforismo suscita dificultades de orden interpretativo que serán abordadas con detenimiento en la siguiente sub-sección, cuando presentemos la problemática noción de "hecho negativo".

${ }^{7}$ Cuidado: mi propósito aquí es meramente didáctico; no estoy afirmando que SCHOPENHAUER ES UN SER HUMANO sea un hecho atómico. El TLP no ofrece ninguna instancia de estas entidades y, seguramente a ojos de Wittgenstein, SCHOPENHAUER ES UN SER HUMANO no podría ser considerado rigurosamente como un ejemplo de esta clase de hechos. La misma nota de cautela corre para todos los ejemplos posteriores de hechos atómicos y de objetos.

Por otro lado, si se objetase a mi ejemplo el hecho de que "es un ser humano" no parece denotar ningún objeto, podría replicarse que, de hecho, la semántica de la lógica de primer orden sí lo trata como tal, pues lo interpreta como un símbolo de predicado al cual se asigna la clase de todos los objetos que satisfacen la condición de ser seres humanos (es decir, la humanidad). 
§2.034). ${ }^{8,9}$ Esta dimensión estructural es importante (entre otras cosas) porque, al exhibir las coyunturas intrínsecas de los hechos, garantiza la adecuación del análisis que el TLP desarrolla en sus primeras secciones. ${ }^{10,11}$ Por tanto, gracias a la estructura interna que poseen los hechos, Wittgenstein se asegura de que su análisis "corte" el mundo en sus "naturales articulaciones". ${ }^{2}$

En la medida en que en el contexto de los hechos atómicos los objetos se encuentran inmediatamente conectados entre sí, como "eslabones de una cadena" (\$2.03), el análisis metafísico emprendido por el joven Wittgenstein topa aquí con su límite. Los objetos no admiten ningún tipo de descomposición ulterior: con ellos nos es dado lo absoluta y metafísicamente simple, "la substancia del mundo" (\$2.021), las piezas más básicas del universo tractariano. Dado que los objetos son los únicos constituyentes de los hechos atómicos, la estructura de un hecho atómico consiste solamente en la manera en que los objetos que lo conforman están conectados entre sí. Por consiguiente, no existe ningún elemento metafísico responsable de conectar los objetos que forman parte de un hecho atómico. Esto no significa, naturalmente, que los hechos atómicos sean un mero agregado de objetos, pues los hechos atómicos son, como sabemos, entidades dotadas de una estructura: ${ }^{13}$ sin embargo, la idea de que los únicos constituyentes de un hecho

8 "La estructura de un hecho consta de las estructuras de los estados de cosas" (§2.034).

${ }^{9}$ En la medida en que el TLP admite la existencia de lo que más adelante llamaremos hechos "No-P" (hechos moleculares constituidos por hechos atómicos inexistentes) y de hechos "agregativos" ( v.gr. SCHOPENHAUER ES UN SER HUMANO Y BUCÉFALO UN CABALLO; cfr. §2, §2.06), cualquier hecho molecular (existente) puede analizarse como (i) un agregado de hechos atómicos existentes; o (ii) un agregado de hechos No-P; o (iii) un agregado de ambos tipos de hechos. Consúltese la sub-sección 1.2.

${ }^{10}$ La dimensión estructural de los hechos tendrá un papel fundamental a la hora de dar una respuesta satisfactoria a la cuestión crucial del TLP. Para más detalles, consúltese la sub-sección 2.1.

${ }^{11}$ Nótese que parecería inadecuado descomponer un hecho molecular como PARÍs ES LA CAPITAL DE FRANCIA Y LONDRES ES LA CAPITAL DE INGLATERRA en las partes PARÍS ES LA, por una lado, y CAPITAL DE FRANCIA Y LONDRES ES LA CAPITAL DE INGLATERRA, por el otro. Esto parece artificial porque de tal análisis no resulta nada que podamos reconocer como un hecho.

${ }^{12}$ Platón, Diálogos, 1985, Madrid, Gredos, traducción de Carlos García Gual, M. Martínez Hernández y E. Lledó Íñigo, p. 385 (265e-266e).

13 "En un estado de cosas los objetos están relacionados unos con otros de un modo y manera determinados", 2.031 . 
atómico sean objetos sugiere que éstos no son "entidades saturadas", metafísicamente "redondeadas" o completas, tal como Frege famosamente pensó. Por el contrario: los objetos deben poseer "ehoyos", muy a la manera de los conceptos en la metafísica fregeana, ${ }^{14}$ en virtud de los cuales se pueden imbricar mutuamente y de esta forma llegar constituir un hecho atómico. ${ }^{15}$ Esta concepción de los objetos tractarianos es útil para explicar por qué no todas las concatenaciones de objetos producen un estado de cosas, pues si los objetos en efecto poseen hoyos, entonces es plausible pensar que parte de la función de estos orificios consiste en restringir el conjunto de las cosas con las que los objetos pueden conectarse. ${ }^{16}$ Por lo demás, esta idea casa particularmente bien con la noción tractariana de forma lógica de los objetos, introducida por Wittgenstein en la $\$ 2.0141$ y que nos es preciso abordar antes de cerrar esta sub-sección:

2.011 Es esencial a las cosas el que puedan ser parte constituyente de un estado de cosas.

2.012 En lógica nada sucede de forma accidental: si una cosa puede ocurrir en un estado de cosas, entonces la posibilidad de tal estado de cosas tiene que estar ya prejuzgada en la cosa en cuestión.

2.014 Los objetos contienen la posibilidad de todas las situaciones.

2.0141 La forma de un objeto es la posibilidad de su ocurrencia en un estado de cosas.

${ }^{14}$ Ver, por ejemplo, su artículo "Función y concepto", en G. Frege, Ensayos de semántica y filosofía de la lógica, 1985, Madrid, Tecnos, edición, introducción, traducción y notas de L. M. Valdés Villanueva, pp. 53-83.

15 "Even though Wittgenstein's objects were quite unlike Frege's, they were like Frege's concepts in that they were also unsaturated and in need of completion. [...] Wittgenstein's objects have 'holes', like Frege's concepts, so that when we put them together, there may emerge a new, nonobjectual sort", en J. A. Coffa, The Semantic Tradition from Kant to Carnap, 1998, Cambridge, Cambridge University Press, p. 150.

${ }^{16}$ Este fenómeno se ilustra con el siguiente ejemplo. Sabemos que NAPOLEÓN NACIÓ EN CÓRCEGA es un hecho; pero también sabemos que CÓRCEGA NACIÓ EN NAPOLEÓN no solamente no es un hecho, sino que ni siquiera puede serlo; sin embargo, ambas combinaciones involucran exactamente los mismos objetos. Por consiguiente, no es el caso que cualquier concatenación de objetos genere un hecho, pues para que algo sea un hecho, este algo debe exhibir una estructura objetual apropiada. La idea desarrollada en éste y en párrafos subsiguientes consiste en que los hoyos de los objetos son los responsables directos de que algunas organizaciones de objetos, en contraste con otras, sean susceptibles de constituir un hecho. 
De acuerdo con el TLP, un objeto puede poseer propiedades internas o propiedades externas. ${ }^{17}$ Las propiedades externas de un objeto $\alpha$ son aquellas que $\alpha$ posee contingentemente, esto es, aquellas que hubiera podido no tener, mientras que las propiedades internas de $\alpha$ constituyen sus propiedades esenciales, aquellas que no nos es posible imaginar que $\alpha$ no ejemplifique. ${ }^{18}$ Dada esta terminología, podemos expresar la idea contenida en la $\$ 2.012$ diciendo que si $\alpha$ posee la posibilidad de verse involucrado en un determinado estado de cosas, entonces tal posibilidad es una propiedad interna de $\alpha$, una posibilidad que se encuentra inscrita en la mismísima naturaleza de $\alpha$. En otras palabras, si es posible que $\alpha$ aparezca en un determinado estado de cosas, entonces es necesario que sea posible que $\alpha$ aparezca en tal estado de cosas. ${ }^{19,20}$ Ahora bien, si consideramos el conjunto $\mathrm{F}$ de todos los hechos atómicos posibles susceptibles de contener a $\alpha$, y si tenemos en cuenta que cada uno de estos hechos constituye una parte de la naturaleza de $\alpha$, entonces tenemos que concluir que $\mathrm{F}$ es el conjunto de todas las propiedades internas de $\alpha$. Por consiguiente, al contener todos los estados de cosas posibles en los cuales $\alpha$ puede verse involucrado, $\mathrm{F}$ constituye la naturaleza o, en terminología tractariana, la forma lógica de $\alpha(\$ 2.0141)$; por esta razón, Wittgenstein afirma que "del mismo modo en que no podemos en modo alguno pensar objetos espaciales fuera del espacio, ni temporales fuera del tiempo, tampoco podemos pensar ningún objeto fuera de la posibilidad de su combinación con otros objetos" (§2.0121). Nótese que la cita anterior implica que, al ser la forma lógica una característica constitutiva de la objetualidad, esta forma

${ }^{17} \mathrm{Cfr}$. $\$ 2.01231$ : "Para conocer un objeto, no tengo, por cierto, que conocer sus propiedades externas, pero sí todas sus propiedades internas".

${ }^{18} \mathrm{Cfr}$. $\S 2.0123-2.01231$. Aquí es particularmente relevante subrayar que el TLP asume que la concebibilidad implica la posibilidad. $C f r$. $\$ 3.02$ : "Un pensamiento contiene la posibilidad de la situación que él piensa. Lo que es pensable es también posible".

${ }^{19}$ Esto nos indica que el sistema de lógica necesario para capturar los principios modales que se despliegan en el TLP debe ser tan fuerte como S5, que se caracteriza por incorporar (además del axioma (M) y del axioma de Necesitación (Nec)) el axioma (S5): $\diamond p \rightarrow \square \diamond p$ (léase "si $p$ es posible, entonces $p$ es necesariamente posible", donde $p$ es una variable del cálculo proposicional).

${ }^{20}$ En otras palabras, dado un objeto $o$, la afirmación "es posible que $F o$ ", de ser verdadera, ha de ser analiticamente verdadera, si suponemos que las verdades analíticas que conciernen a un objeto determinado recogen las propiedades esenciales de ese objeto. 
es una propiedad interna de cualquier cosa que se encuentre en el mundo $\mathrm{y}$, por tanto, que el conjunto de las cosas determina, vía sus formas lógicas, el conjunto de todos los estados de cosas posibles $(\$ 2.0124$, $\S 2.014)$.

En la medida en que la forma lógica de $\alpha$ tiene la función de determinar el conjunto de los objetos que son susceptibles de articularse con $\alpha$ para así constituir un hecho atómico, es plausible pensar que la forma lógica de un objeto tiene todo que ver con el aspecto insaturado que éste presenta y que propugnábamos líneas atrás. Estos hoyos, podríamos pensar, son análogos a las orillas de las piezas de un rompecabezas pues, así como aquéllos restringen la clase de cosas con las cuales un determinado objeto puede acoplarse, éstas limitan el conjunto de las piezas con las cuales un determinado trozo de rompecabezas puede empalmarse. Esta analogía es particularmente apropiada porque nos permite ver asimismo, en el conjunto de todas las piezas que pueden embonar con un determinado fragmento de un rompecabezas, una imagen de lo que constituye la forma lógica de un objeto tractariano, y porque además sugiere que, así como diferentes piezas de un rompecabezas pueden o no poseer las mismas posibilidades combinatorias (si atendemos únicamente a su forma geométrica), dos objetos pueden o no poseer la misma forma lógica. Esto último debe ser el caso puesto que, si todos los objetos poseyesen una misma forma lógica, entonces sus propiedades internas serían idénticas, lo cual no solamente es de por sí bastante inverosímil, sino que haría irrelevante el uso del plural en aforismos como "Una vez que se dan todos los objetos se dan con ello también todos los posibles estados de cosas" (\$2.0124) o "Los objetos contienen la posibilidad de todas las situaciones" (\$2.014). (Si todos los objetos poseyeran una misma forma lógica, entonces con un sólo objeto se darían todos los posibles estados de cosas.) Y, por otro lado, si hubiese tantas formas lógicas como objetos hay, entonces no tendría ningún punto alguno afirmar, como lo hace Wittgenstein en la $\$ 2.0233$, que "Dos objetos de la misma forma lógica sólo se diferencian entre sí-si se prescinde de sus propiedades externas- 
en que son distintos". ${ }^{21,22}$ Por ende, creo que tenemos buenas razones, además de suficiente evidencia textual, para pensar que los objetos tractarianos son entidades insaturadas, que su forma lógica se encuentra determinada por el tipo de insaturación que manifiestan (por los hoyos que estos objetos poseen), y por tanto, que los objetos no constituyen una categoría ontológica uniforme, sino que admite tantas subdivisiones como formas lógicas posean.

\subsection{Hechos positivos y negativos. Hechos No-P. Espacio lógico. Realidad}

Es el momento de abordar un segundo distingo que el TLP traza entre los hechos: la distinción entre hechos positivos y negativos. A este respecto, Wittgenstein nos dice:

2.04 La totalidad de los estados de cosas existentes es el mundo.

$2.05 \mathrm{La}$ totalidad de los estados atómicos existentes determina también qué estados de cosas no existen.

2.06 La existencia y no existencia de estados de cosas es la realidad. (Llamamos también a la existencia de estados de cosas hecho positivo, a la no-existencia hecho negativo).

2.063 La realidad al completo es el mundo.

Si tenemos en cuenta que un hecho positivo es simplemente un hecho atómico existente o actual (v.gr. SCHOPENHAUER ES UN SER HUMANO), podría parecernos que todo el punto de la $\$ 2.04$ consiste en presentar de un modo más fino la idea contenida en el pasaje §1-1.12: el mundo es la totalidad de los hechos, de los hechos atómicos existentes. Ésta, después de todo, parece ser una consecuencia inmediata de la funda-

${ }^{21}$ Las propiedades externas son aquellas que un objeto de hecho posee, esto es, aquellas que, al ser instanciadas por uno o más objetos, dan lugar a los hechos atómicos actuales que involucran tales objetos.

22 "It pertains to the nature of various kinds of objects that they can enter into a certain limited range of combinations. It is in this way that objects can be different in their internal properties or, alternatively, different in their form", en R. J. Fogelin, Wittgenstein, 1976, Londres, Routledge \& Kegan Paul, p. 7. 
mentalidad que el TLP, como vimos, le otorga a los hechos atómicos. Sin embargo, una vez llegados a las secciones $\$ 2.06$ y $\$ 2.063$ nuestro panorama se complica, pues en estas secciones Wittgenstein nos pide identificar el mundo, no con la totalidad de los hechos positivos, sino con la "realidad al completo", con el conjunto de todos los hechos positivos y negativos; no obstante, un hecho negativo es, de acuerdo con la §2.06, un estado de cosas inexistente; ¿cómo puede, entonces, ser el mundo a la vez idéntico con la totalidad de los hechos positivos y con la totalidad de hechos positivos y negativos? Y, por otro lado, ¿cómo es posible que una parte del mundo esté dada por aquello que, por definición, se encuentra desprovisto de existencia (por los hechos negativos)? ${ }^{23}$ La cosa parece desesperanzadamente oscura y sin duda lo es, tomadas estas secciones con plena literalidad; sin embargo, creo que con una interpretación cuidadosa de la noción de "realidad" que el TLP maneja es posible zanjar esta incongruencia. En lo que resta de esta sección orientaremos nuestros esfuerzos hacia este propósito.

Para dar inicio a nuestra tarea será necesario que retomemos la noción de forma lógica de los objetos que dejamos algunos párrafos atrás y que, con su ayuda, introduzcamos un nuevo concepto. Pues bien, la forma lógica de un objeto $\alpha$ es el conjunto de los hechos atómicos en los cuales $\alpha$ es susceptible de aparecer. Puesto que la forma lógica es un rasgo esencial de los objetos y que éstos son eternos (esto debe ser así si los objetos, como asume el TLP, son la substancia del mundo), ${ }^{24}$ es necesario concluir, como Wittgenstein lo hace en la $§ 2.0124$, que "una vez que se dan todos los objetos se dan con

${ }^{23}$ En la literatura consagrada al TLP existen varias tentativas de resolución a este problema. Algunos de los más salientes intentos pueden ser consultados en M. Black, A Companion to Wittgenstein's Tractatus, 1964, Ithaca, NY, Cornell University Press; Fogelin, Wittgenstein, op. cit.; J. Griffin, Wittgenstein's Logical Atomism, 1964, Oxford, Clarendon Press; y M. Morris, Routledge Philosophy Guidebook to Wittgenstein's Tractatus, 2008, Abingdon, Routledge. Más recientemente, G. Casey ha elaborado una novedosa interpretación que busca disolver la contradicción que parece existir en las secciones citadas. Consúltese la siguiente liga: http://www. ucd.ie/philosophy/staff/gerardcasey/casey/Wittgenstein.pdf.

${ }^{24} \mathrm{Cfr}$. $2.024, \S 2.027$. La tesis de la eternidad e inmutabilidad de los objetos es una característica esencial del atomismo lógico-ontológico que Wittgenstein desarrolla en el TLP. Para más sobre este punto, consúltese R. J. Fogelin, op. cit., pp. 3-17. 
ello todos los posibles estados de cosas". El TLP llama espacio lógico al conjunto de todos los hechos atómicos posibles, al ámbito inmutable que incluye todas las conexiones posibles entre objetos contenidas en sus formas lógicas. No obstante, en la medida en que el mundo no contiene hechos posibles, sino solamente actuales (el mundo es, recordemos todo lo que es el caso), el espacio lógico no es una genuina parte o un ítem del mundo: ambas cosas, mundo y espacio lógico, difieren como lo hacen un trapecio bidimensional y el plano $\mathbb{R}^{2}$ en el que este trapecio se encuentra inscrito. El mundo presupone el marco de todo aquello que puede llegar a ser parte de él, pero este marco no es ni se encuentra en el mundo, sino que funciona como su condición de posibilidad. ${ }^{25}$

Pese a que el espacio lógico contenga todas las concatenaciones de objetos que pueden dar lugar a hechos positivos, muchas de estas combinaciones no llegan, por razones contingentes, a transitar a la actualidad en un momento dado. El TLP llama hechos negativos a todas las conexiones entre objetos que permanecen, en un momento determinado, en un estado de mera potencia. ${ }^{26}$ En este sentido, y asumiendo que Schopenhauer y el optimismo son un par de objetos tractarianos, podríamos decir que SCHOPENHAUER ES OPTIMISTA es un hecho negativo pues, aunque en efecto Schopenhauer no haya sido optimista, el autor de Parerga y Paralipómena pudo claramente haberlo sido (de haber meditado un poco más, presumo). Sin embargo, quizá esto no sea suficiente para disipar la incomodidad que muchas veces genera el hablar de hechos negativos. Porque, podríamos pensar, ¿cuál es el punto de considerar a SCHOPENHAUER ES OPTIMISTA como un hecho, si sabemos que es algo que no acaece y, por tanto, que no hace parte del mundo?

25 "[The] notions of logical space and fact are correlative, but this does not require that logical space be viewed as a constituent added to facts. That facts are in this space means that logical space belongs internally to what it is to be a fact. This does not make logical space a reality external to facts, which belongs to the furniture of the universe. When Wittgenstein writes "The facts in logical space are the world," it is precisely to emphasize that logical space is not an additional entity but a condition of facticity as such", en E. Friedlander, Signs of SenseReading Wittgenstein's Tractatus, 2001, Cambridge (MA), Harvard University Press, p. 30.

${ }^{26}$ En lo que sigue, pues, los calificativos 'positivo' y 'negativo' han de entenderse como aplicándose exclusivamente a estados de cosas. 
¿Qué sentido tiene, en fin, hablar de hechos que no acaecen? La respuesta a esta pregunta es la siguiente: está claro que SCHOPENHAUER ES OPTIMISTA (suponiendo que éste sea un hecho atómico) no es un hecho positivo, que no hace parte del mundo, y esto nadie lo pone en duda; sin embargo, y por esta misma razón, es innegable que éste sí es un genuino aspecto del mundo: que SCHOPENHAUER ES OPTIMISTA no existe. ${ }^{27}$ En otras palabras, la inexistencia de SCHOPENHAUER ES OPTIMISTA sí caracteriza el aspecto que el mundo posee en un instante dado, lo cual implica que, aunque SCHOPENHAUER ES OPTIMISTA no sea una parte del mundo, SCHOPENHAUER NO ES OPTIMISTA sí lo es. Claro, en la medida en que está constituido por el hecho negativo SCHOPENHAUER ES OPTIMISTA, SCHOPENHAUER NO ES OPTIMISTA no es un hecho atómico (y por tanto no puede ser un hecho negativo), pero esto no nos proporciona evidencia suficiente para concluir que SCHOPENHAUER NO ES OPTIMISTA no sea el caso. Por consiguiente, todo el punto de hablar de hechos atómicos que no existen consiste en que ellos nos permiten dar razón de otros hechos que sí existen y que, por tanto, son responsables del semblante del mundo en un momento determinado. Vistas así las cosas, el mundo no sólo se conforma de todos los hechos positivos sino, asimismo, de todos los hechos moleculares de la forma, digamos, NO-P, donde $\mathrm{P}$ es un hecho negativo. ${ }^{28,29}$ Nótese que, según esta perspectiva, el mundo es en verdad todo lo que acaece; pero todo lo que acaece debe analizarse como consistiendo en todos los hechos positivos, por un lado, y todo lo que existe en virtud del no-acaecimiento de un hecho atómico (los hechos No-P), por el otro. ${ }^{30}$

27 “'According to Wittgenstein's use of the term 'fact', the nonexistence of a state of affairs is not itself a fact (although the negation of a nonexistent state of affairs is one). Rather, we should say that the nonexistence of state of affairs has reality", en E. Friedlander, op. cit., p. 32.

28 "It is one of Wittgenstein's distinctive claims that this larger list -the list of all the atomic facts and all the negations of possible but not actual atomic facts- suffices to fix the full range of facts", en M. Morris, op. cit., p. 51.

${ }^{29}$ En lo sucesivo me referiré a todos los hechos actuales que se desprenden de la inexistencia de un hecho atómico como 'hechos NO-P'.

${ }^{30}$ Por esta razón, analizar los hechos como "la existencia de estados de cosas" ( $(2)$ parece inapropiado, como mencionaba en la nota 6 . Abordaré este problema un poco más adelante. 
Ahora bien, si atendemos a la $\$ 2.06$ : "La existencia y no existencia de estados de cosas es la realidad. (Llamamos también a la existencia de estados de cosas hecho positivo, a la no existencia hecho negativo)", resulta claro que su propósito consiste en caracterizar a la realidad como algo ligado a la existencia y a la inexistencia de los hechos atómicos posibles. ${ }^{31}$ Pero es importante observar que aquello que en esta sección se identifica con la realidad no es primariamente los hechos existentes e inexistentes, sino la existencia e inexistencia misma que éstos exhiben. La "marca característica" de lo real, podríamos decir, aquello que distingue a la realidad del ámbito de lo posible, es que cualquier estado de cosas que se encuentre en la realidad es, o bien existente, o bien inexistente, mientras que en el marco del espacio lógico la cuestión de la existencia o de la inexistencia de los hechos atómicos simplemente no se plantea. En este sentido, el punto de la $\$ 2.06$ podría ponerse de la siguiente manera: afirmar que SCHOPENHAUER ES OPTIMISTA forma parte de la realidad conlleva un compromiso con la existencia o con la inexistencia de este hecho que no se adopta al afirmar que SCHOPENHAUER ES OPTIMISTA forma parte del espacio lógico. Por tanto, al decir "SCHOPENHAUER ES OPTIMISTA forma parte de la realidad"

74 vehiculamos estrictamente más información que cuando decimos "SCHOPENHAUER ES OPTIMISTA forma parte del espacio lógico". En ambos casos, aquello a lo que aludimos es lo mismo, esto es, hablamos acerca de la misma "coordenada" en el espacio de posibilidades, ${ }^{32}$ pero cuando ubicamos a SCHOPENHAUER ES OPTIMISTA en la realidad suponemos que esta coordenada exhibe una polaridad negativa o positiva. ${ }^{33}$ En este orden de ideas, podríamos decir entonces que la realidad es la imagen polarizada del espacio lógico puesto que, pese a ser equi-

${ }^{31}$ En la versión original del TLP, la palabra utilizada es "Wirklichkeit", la cual se puede traducir como "realidad", pero asimismo como "actualidad".

${ }^{32}$ Esta idea tendrá repercusiones importantes en el ámbito de la teoría pictórica desarrollada por el TLP, en particular con respecto a la noción tractariana de "verdad". Véase el final de la sub-sección 2.1 y la sub-sección 2.2.

${ }^{33}$ Por tanto, la oración "Schopenhauer es optimista forma parte de la realidad" es ambigua, pues no nos informa qué polaridad tiene el hecho posible Schopenhauer es optimista, sino sólo que exhibe una de dos polaridades posibles: existente o inexistente. 
valentes en términos extensionales, el espacio lógico es existencialmente neutral mientras que la total realidad se encuentra existencialmente cargada.

Así pues, el asunto que nos queda pendiente consiste en resolver la tensión generada por la conjunción de las tesis contenidas en los aforismos 2.04 y 2.063. Naturalmente, al menos una de estas dos secciones requiere ser reformulada si deseamos eliminar la inconsistencia que hemos expuesto al inicio de esta sub-sección. Mi propuesta es que ambas lo requieren. ${ }^{34}$ En virtud de lo que hemos visto en el párrafo anterior, debería resultar obvio que identificar el mundo y la total realidad, tal como la $\$ 2.063$ propone, simplemente no es una opción. La razón de esto es que la total realidad, de acuerdo con nuestra lectura, está parciamente constituida por hechos negativos, mientras que el mundo no puede incluir tales cosas si éste es la totalidad de lo que acaece $(\S 1)$. Aquí es importante observar que cuando afirmo que el mundo es "la totalidad de lo que acaece" no presumo que el mundo sea lo mismo que "la totalidad de los estados de cosas existentes", como la $\$ 2.04$ asevera. Esto es importante porque indica que mi rechazo de la identidad mundo $=$ realidad que se expresa en la $\$ 2.063$ se justifica en consideraciones independientes de la tensión creada por la conjunción de esta sección y de la §2.04 y que ahora intentamos remediar. En otras palabras, la inconsistencia que se crea al identificar el mundo y la realidad subsistiría aun si el TLP jamás hubiese contenido la $\S 2.04$, esto es, al margen de que Wittgenstein haya o no respaldado la identidad mundo $=$ hechos positivos. ${ }^{35}$ Es así porque, si lo

${ }^{34}$ Aunque no por las mismas razones. Reformular la $\$ 2.063$ es necesario para desarticular una contradicción, pero una que depende de tesis más importantes que la contenida en la $\$ 2.04$ (véase más adelante). En cambio, la $\$ 2.04$ necesita ser reformulada para hacer justicia al carácter real de los hechos negativos; mencionado en Friedlander, op. cit., p. 32, y por mí mismo algunos párrafos arriba, cuando intentaba elucidar la noción de hecho negativo (véase nota 28 ).

${ }^{35}$ De otro modo, mi argumento para rechazar la formulación de la $§ 2.063$ solamente consistiría en afirmar que ésta y la \$2.04 generan una contradicción. Pero mi punto aquí es que la contradicción se genera no solamente por conjunción de estas dos tesis, sino por la conjunción de la $\$ 2.063$ y de una sección aún más fundamental para el tejido del TLP, a saber, la $\S 1$. Por tanto, la $\$ 2.063$ tiene que estar mal. Y por lo demás, un poco más adelante ofreceré razones para considerar que la formulación de la $\$ 2.04$ también es defectuosa. 
analizamos a la manera en que lo hace la $\S 1$, no es posible que el mundo contenga hechos atómicos que, por definición (\$2.06) son inexistentes, mientras que la inclusión de tales hechos es algo que sabemos caracteriza el espacio de lo real, en contraste con el espacio de lo posible.

No obstante, ésta no es la única razón por la cual la formulación de la $\S 2.063$ resulta inadecuada. En efecto, una ojeada a la $\S 1.12$ ("[La] totalidad de los hechos determina lo que es el caso y también lo que no es el caso") y a la $\$ 2.05$, que le hace eco ("La totalidad de los estados de cosas existentes determina también qué estados de cosas no existen"), sugiere que la relación que subsiste entre la realidad y el mundo no es una de identidad, sino una de determinación. Esta idea no debería causarnos sorpresa pues, ultimadamente, lo único que necesitamos para describir la extensión de la realidad en un momento dado es la lista de todos los hechos positivos junto con la de todos los hechos No-P. Partiendo de ambas listas y aplicando al conjunto de los hechos No-P el mismo tipo de análisis que el TLP desarrolla en sus secciones iniciales, es posible obtener el listado de los hechos positivos y negativos en ese momento, es decir, una descripción exhaustiva de la realidad en ese instante. Así pues, dadas por un lado la evidencia que el TLP proporciona y, por el otro, la inconsistencia que genera la formulación de la $\$ 2.063$ con una de las tesis más sobresalientes del TLP (a saber, la identificación del mundo con la totalidad de lo que es el caso), me parece que la mejor estrategia para resolver el conflicto que surge al identificar el mundo y la realidad radica en asumir que la relación que el mundo y la realidad sostienen no es una de identidad, sino una de determinación. ${ }^{36}$

Antes de cerrar la presente sub-sección me parece conveniente ponderar, como lo advertíamos ya líneas arriba, la necesidad de reformular la §2.04: "La totalidad de los estados de cosas existentes es el mundo". Pues más allá de la inconsistencia que genera este aforismo en conjunción con la $\S 2.063$ (y que se desarticula exitosamente gracias a la reformulación que hemos propugnado en el párrafo anterior), la §2.04 suscita

${ }^{36}$ El énfasis en la §2.063 es mío. Por otro lado, esta interpretación es, grosso modo, la misma que la defendida por R. J Fogelin (op. cit.), por Morris (op. cit.) y por Friedlander en op. cit. 
el siguiente problema. Supongamos que SCHOPENHAUER ES OPTIMISTA es atómico; dada esta asunción, y dado que Schopenhauer es uno de los filósofos más gruñones en la historia del pensamiento occidental, se sigue que SCHOPENHAUER ES OPTIMISTA es un hecho negativo. Ahora bien, según el TLP el mundo es todo lo que es el caso y sabemos que SCHOPENHAUER ES OPTIMISTA, pese a ser un estado de cosas real, no forma parte del mundo. Pero ahora consideremos SCHOPENHAUER NO ES OPTIMISTA. Este hecho tiene que ser molecular si se encuentra constituido por uno que, ex hypothesi, es atómico. Por otro lado, si SCHOPENHAUER ES OPTIMISTA no existe, entonces estamos obligados a afirmar que SCHOPENHAUER NO ES OPTIMISTA sí lo hace. ${ }^{37}$ Por consiguiente, SCHOPENHAUER NO ES OPTIMISTA debe ser un hecho molecular que forma parte del mundo, pero que no se encuentra constituido por ningún estado de cosas existente. Pero esto contradice directamente lo que Wittgenstein sostiene en la $\$ 2.04 .^{38}$

Creo que es posible eliminar esta tensión apelando a dos estrategias diferentes, una más radical que otra. La primera consiste en ignorar por completo la $\S 2.04$. Pese a su radicalidad, creo que este curso de acción es el más recomendable: el aforismo, en última instancia, me parece dispensable a la luz de lo que ya ha sido dicho hasta ese punto y de lo

${ }^{37} C f r$. $\$ 4.023$ : "La realidad tiene que quedar fijada por la proposición de modo que sólo quepan dos alternativas: sí o no". Por consiguiente, una proposición debe tener uno y sólo uno de dos valores de verdad posibles, "verdadero" y "falso". De esto se sigue, por consideraciones lógico-lingüísticas que estudiaremos en la sub-sección 2.2, que o bien SCHOPENHAUER ES OPTIMISTA es el caso, o bien SCHOPENHAUER NO ES OPTIMISTA lo es, pero no ambos, ni ninguno. (Por supuesto, estoy considerando, con fines didácticos, que no existe nada que sea optimista y que no sea optimista, esto es, que la distinción optimista/no-optimista es exhaustiva y mutuamente excluyente. Cualquier lector que se sienta a disgusto con esta asunción puede utilizar el par de predicados exhaustivos que más le sienten.)

${ }^{38}$ Este punto ha sido observado también por M. Morris. Aludiendo a una carta dirigida por Wittgenstein a Russell, Morris dice: “And in the letter to Russell, Wittgenstein continues: 'Tatsache [fact] is what corresponds to the logical product [conjunction] of elementary prop[osition]s when this product is true' (CL, p. 125). In fact, this cannot be quite right, since it leaves out what he elsewhere (TLP 2.06) calls 'negative' facts, i.e. facts that such and such is not the case" (M. Morris, op. cit., p. 365). Nótese que aquí Morris incurre en un pequeño error (puramente terminológico), pues los hechos negativos son, en el contexto del TLP y de acuerdo con nuestra interpretación, estados de cosas inexistentes, y como tal no pueden ser "hechos de que tal o cual cosa no es el caso". Éstos corresponden a los hechos que hemos denominado "No-P". 
que es dicho inmediatamente después. ${ }^{39}$ La otra posibilidad consiste en reformular la $\$ 2.04$ de tal suerte que haga explícita la idea de que la descomposición de un hecho molecular puede desembocar, o bien en un conglomerado de hechos positivos o bien en uno de hechos negativos. En todo caso, afirmar que los únicos hechos existentes son positivos o agregados de hechos positivos, nos dejaría con el problema expuesto en el párrafo anterior y también con un enigma irresoluble en lo que concierne a las proposiciones negativas verdaderas (dados los compromisos semánticos del TLP que estamos a punto de abordar), ${ }^{40}$ y con la cuestión de explicar el propósito de introducir hechos negativos en la metafísica tractariana. Por consiguiente, en la medida en que no parece posible tomar al pie de la letra lo expresado en la $\$ 2.04$ sin afectar de manera substancial tanto la metafísica como la teoría pictórica desarrollada en el TLP, me parece que, si realmente deseamos preservar la $\$ 2.04$ dentro del tejido del texto, es preciso alterar su contenido para hacer explícitas las modificaciones que hemos avanzado en este párrafo.

${ }^{39}$ Justo después encontramos la $\$ 2.05$ : "La totalidad de los estados de cosas existentes determina también qué estados de cosas no existen" y la §2.06: "La existencia y no existencia de estados de cosas es la realidad. (Llamamos también a la existencia de estados de cosas hecho positivo, a la no existencia hecho negativo)".

${ }^{40}$ Para ver el problema, supongamos que "Schopenhauer no es optimista" es una oración verdadera, y que el hecho SCHOPENHAUER ES OPTIMISTA es atómico (y por tanto negativo). En dado caso, según el TLP, "Schopenhauer no es optimista” figura un hecho existente. ¿Pero cuál podría ser tal hecho, una vez suponemos que todo lo que existe son estados de cosas existentes y sus compuestos? Alguien podría pensar que el hecho en cuestión es SCHOPENHAUER ES PESIMISTA. Pero tal hecho deberá ser o bien atómico o bien molecular. Si es atómico, entonces el hecho atómico SCHOPENHAUER ES OPTIMISTA no sería independiente del hecho atómico SCHOPENHAUER ES PESIMISTA, contrariamente a la tesis que Wittgenstein respalda en las $\S \S 2.061-2.062$, puesto que la existencia de uno implicaría la inexistencia del otro. Si es molecular, y si suponemos que SCHOPENHAUER ES PESIMISTA consiste en la concatenación de los hechos atómicos $\mathrm{A}_{1}, \mathrm{~A}_{2} \ldots \mathrm{A}_{n}$, entonces, dado que (como sabemos) un hecho molecular no es independiente metafísicamente de los hechos atómicos que lo constituyen, se seguiría que SCHOPENHAUER ES OPTIMISTA no es independiente o bien de $\mathrm{A}_{1}$, o bien de $\mathrm{A}_{2}$, o bien de $\mathrm{A}_{n}$. Y entonces tendríamos una situación similar a la anterior: pues cualquiera que sea el hecho atómico responsable de la existencia de SCHOPENHAUER ES PESIMISTA deberá ser responsable de la inexistencia de SCHOPENHAUER ES OPTIMISTA, violentando así la tesis de independencia mencionada. 


\section{Semántica del TLP}

Hemos dedicado la sección anterior a recorrer la metafísica expuesta en el TLP y así determinar cuáles son, de acuerdo con Wittgenstein, los aspectos del mundo que condicionan la confección de cualquier lenguaje posible. En la presente sección llevaremos a cabo una exposición del segundo movimiento del TLP, en el cual Wittgenstein pretende determinar las condiciones responsables de las capacidades representativas del lenguaje, y con ello, brindar una respuesta definitiva a lo que hemos denominado la "Cuestión crucial del TLP".

2.1 Figuras. Elementos figurativos. Relación figurativa. Forma de figuración

Wittgenstein da inicio a la segunda parte de su respuesta a la Cuestión crucial (la llamada "teoría figurativa (o pictórica) del lenguaje") de la siguiente manera:

2.1 Nos hacemos figuras de los hechos.

2.11 Una figura representa una situación en el espacio lógico, la existencia y no existencia de estados de cosas.

2.12 Una figura es un modelo de la realidad.

No me parece inadecuado, antes de entrar en materia, precisar un poco la noción de "modelo" que aparece en la $\$ 2.12$. Pues aunque en la idea de "modelo" confluyen típicamente conceptos como los de "intención" (ya que un modelo es algo que usamos con un determinado fin), "objeto de representación" (porque es un modelo de algo) y "modo de representación" (pues involucra una manera en la cual el objeto modelado es presentado o reproducido), ${ }^{41}$ a ojos del autor del TLP debía de ser posible responder a la Cuestión crucial sin apelar de manera esencial al fenómeno de la intencionalidad. ${ }^{42}$ De hecho,

${ }^{41}$ Ésta no pretende ser una lista exhaustiva.

${ }^{42}$ Muestra de ello es, por ejemplo, que la palabra 'intención' no aparece nunca en el TLP. En su introducción al TLP, Russell expresa la misma idea: “[Está] el problema de qué es lo 
pensar lo contrario, según Wittgenstein, sería análogo a colocar el carro delante de los bueyes, ya que si algo que caracteriza a los estados mentales es la posesión de un contenido, entonces se hace preciso saber qué es, en general, un contenido, para poder determinar cómo logran nuestros estados mentales poseer tal cosa. La intención, la creencia et alia son estados mentales que suponen, para su realización, que algo hay que puede querer ser dicho, creído, etc.; pero eso que puede querer ser dicho o creído es precisamente aquello que es descrito, según el TLP, mediante concatenaciones significativas de símbolos de nuestro lenguaje. ${ }^{43}$ Por consiguiente, si bien el pensamiento del contenido de un signo es el pensamiento de algo que este signo puede vehicular, el hecho de que los signos puedan vehicular un contenido no depende del pensamiento de éste, sino (y diciendo esto me adelanto un poco) de una relación interna que subsiste entre signo y contenido. ${ }^{44}$

En franco contraste con la escasa atención que presta al fenómeno de la intencionalidad (la palabra "intención" no aparece nunca en el TLP), Wittgenstein dedica una buena parte del TLP al análisis de los otros dos conceptos que, decíamos, típicamente confluyen en la noción de "modelo": los de un objeto y un modo de representación. En este sentido, la §2.1 identifica el objeto de la representación lingüística con los hechos (y

que efectivamente ocurre en nuestra mente cuando empleamos el lenguaje con la intención de significar algo con él; este problema pertenece a la psicología”, y por tanto, no cae dentro del objeto de investigación del TLP que, al ser de orden más general, está supuesto en toda investigación psicológica.

${ }^{43}$ Wittgenstein le dice a Russell en una carta dirigida desde Monte Cassino: "I don't know what the constituents of a thought are but I know that it must have such constituents which correspond to the words of Language. Again the kind of relation of the constituents of thought and of the pictured fact is irrelevant. It would be a matter of psychology to find it out", en B. McGuinness y G.H. von Wright, Ludwig Wittgenstein: Cambridge Letters (Correspondence with Russell, Keynes, Moore, Ramsey and Sraffa), 1995, Oxford, Blackwell Publishers, pp. 98-9. (Las negritas son mías.)

${ }^{44}$ Cfr. §4.014: "La placa del gramófono, el pensamiento musical, la notación musical, las ondas sonoras, están todos ellos entre sí en la relación interna de figuración que se da entre lenguaje y mundo". Recuérdese también el célebre pasaje de los Notebooks: "Logic must take care of itself", L. Wittgenstein, Notebooks 1914-1916, 1961, Nueva York, Harper \& Row Publishers, p. 2e. 
más precisamente, en la $\S 2.11$, con los hechos atómicos $),{ }^{45}$ mientras que la siguiente sección nos ilustra acerca de la característica general que hace de algo un modelo de un hecho o, en terminología tractariana, una figura ("Bild"): el "representar una situación en el espacio lógico, la existencia y no existencia de estados de cosas”. Dada esta generosa caracterización, deben considerarse como figuras cosas tan variadas como un retrato o un busto de Marie Curie, una fotografía de los Campos Elíseos, la partitura de La Heroica, las ecuaciones de Maxwell y la imagen que surge en nuestras mentes cuando pensamos en Mahatma Gandhi, ya que a todas estas cosas subyace una idéntica capacidad de representar o 'pintar', como encontramos en algunas versiones castellanas del TLP, algún rasgo que el mundo exhibe en un momento determinado (la apariencia de alguien o de algo, la constitución interna de ciertos fenómenos de la naturaleza, etc.).

Ahora bien, existen por lo menos dos características de las figuras que resultan particularmente intrigantes desde un punto de vista filosófico. Si pensamos, por ejemplo, en las ocasiones en las que hemos observado un retrato fotográfico, notaremos que la poderosa inclinación que tenemos de "ver" en la fotografía el rostro de la persona retratada nos hace sumamente difícil (a veces incluso imposible) la tarea de no ver en ella más que una serie de puntos de colores esparcidos sobre una superficie blanca y plana. Así, en su uso cotidiano una figura queda completamente suplantada por aquello que representa y su dimensión simbólica suele opacar cualquier otra dimensión que ésta pueda llegar a tener. ${ }^{46}$ ¿Pero cómo puede suceder esto? ¿De qué modo logra una fotografía exponer algo que es tan diferente a ella? ${ }^{47}$ Esta pregunta nos lleva a reparar en otra característica filosóficamente saliente de las figuras; radica en el hecho de que, en muchas ocasiones,

${ }^{45}$ Lo cual es natural pues, si tomamos en cuenta su fundamentalidad, si somos capaces de figurar estados de cosas, entonces deberíamos ser capaces de figurar hechos compuestos de estados de cosas.

${ }^{46}$ Una patentización bastante dramática de este fenómeno se encuentra en el famoso cuadro La trahison des images de R. Magritte.

${ }^{47}$ Obsérvese que ésta no es sino una manera más colorida de enunciar la Cuestión crucial que anima al TLP. 
las figuras poseen un parecido con aquello que reproducen. Después de todo, parece ser en virtud de tal similitud que nos es posible reconocer el rostro de Gandhi en un pedazo de papel impreso (es decir, en su retrato). Pero quizá en este punto se nos objete que el ejemplo que escogimos es engañoso, ya que si bien es obvio que un retrato tiene un parecido con la cara que representa (y que podríamos explicar en términos de geometría proyectiva), no es para nada claro que exista una semejanza igual entre un rostro y su descripción en, digamos, sánscrito o alemán. ¿Qué parecido pueden tener, finalmente, objetos tan diferentes? ¿No hemos hallado aquí el punto en el que la amalgama que realiza el TLP entre pinturas, fotografías y esculturas, por un lado, y palabras, por el otro, se quiebra?

Puesta muy sucintamente, la réplica de Wittgenstein a esta última pregunta es "no"; sin embargo, exponer el argumento que nuestro autor desarrolla para justificar su respuesta (la llamada 'teoría pictórica del lenguaje') nos tomará un largo trecho. Así que vayamos por partes $y$, para comenzar, concentrémonos en una de las preguntas que nos hacíamos en el párrafo anterior: ¿de qué modo una figura logra poner ante nosotros algo que suele ser tan diferente a ella? En términos tractarianos, esta pregunta puede reformularse de la siguiente manera: ¿de qué manera logra una figura "representar la existencia y no existencia de estados de cosas", esto es, ser un "modelo de la realidad"? La respuesta del TLP va en dos partes. En la primera, Wittgenstein afirma:

2.13 A los objetos les corresponden en la figura los elementos de la propia figura.

2.131 Los elementos de la figura son en ella los representantes de los objetos.

2.14 Una figura consiste en que sus elementos se relacionen unos con otros de modo y manera determinados.

2.141 Una figura es un hecho.

Este pasaje contiene varias ideas que nos es preciso elucidar. En primer lugar observemos que, de acuerdo con las $\S \S 2.13-2.131$, la multiplicidad lógica del hecho (atómico) debe ser la misma que la de 
la figura que lo representa. Esto significa que figuras y estados de cosas figurados deben contar con exactamente el mismo número de simples. Así, si suponemos que $\mathrm{P}$ es un estado de cosas que consiste en la concatenación de, digamos, tres objetos $\alpha, \beta$ y $\gamma$, entonces una figura de $\mathrm{P}$ debe contener tres "signos elementales" $a, b$ y $c$ (los "elementos de la figura") que están en la figura por los objetos en el hecho. Tal correlación entre signos elementales y objetos, que no es otra cosa que la relación de denotación, se denomina "relación figurativa" en el TLP. ${ }^{48,49}$ Gracias a esta relación, una figura "toca" o entra en contacto con el hecho por ella figurado (\$2.1515); pero una figura es, naturalmente, algo más que una mera colección de signos dotados de (la apropiada) denotación, del mismo modo en que un estado de cosas es una entidad por encima de los objetos que articula y no un conglomerado indiscriminado de objetos. Una figura es una colección de signos elementales dotados de referencia y relacionados entre sí de un modo especifico (\$2.14). Si añadimos a esta caracterización de "figura" la idea de que los signos elementales son objetos, entonces obtendremos la tesis contenida en la $\S 2.141$ : "Una figura es un hecho". ${ }^{50} \mathrm{Y}$, en efecto, una de las tesis importantes del TLP es que solamente podemos representar hechos por medio de otros hechos. No podemos usar objetos para este fin porque éstos, al ser simples, no poseen la articulación necesaria para fungir como figuras. ${ }^{51}$ Por tanto, una figura lingüística

48 "Un nombre significa un objeto. El objeto es su significado", §3.203. El alemán reza: "Der Name bedeutet den Gegenstand. Der Gegenstand ist seine Bedeutung".

${ }^{49}$ Por supuesto, la relación figurativa es externa al hecho figurado; de acuerdo con la $\S 2.1513$, la denotación "pertenece a la figura", mas no al estado de cosas figurado. Esta idea es bastante intuitiva, pues no parece haber nada en la naturaleza de un hecho o de los objetos que lo componen que nos compela a correlacionar objetos y nombres de la manera en que lo hacemos en castellano, por ejemplo. Después de todo, la sal hubiese podido llamarse "azúcar" sin que por esto se viesen afectadas ni su composición química ni sus cualidades secundarias.

${ }^{50}$ Esta idea no está expresamente contenida en el TLP, pero debe ser verdadera si tomamos lo afirmado en la $\$ 2.141$ y en la $\$ 2.01$ de manera literal. Por otra parte, la idea general de que un signo pueda ser un objeto no es ajena a la lógica clásica. Piénsese en la prueba estándar de la existencia de un modelo denumerable para cualquier teoría de primer orden consistente (como la que ofrece G. Hunter en su libro Metalogic-An introduction to the Metatheory of Standard First Order Logic, 1971, Berkeley, University of California Press, pp. 182-85).

${ }^{51}$ Vid infra.Para que la relación de representación entre figuras y hechos se dé, es necesario que exista, como veremos inmediatamente, un isomorfismo entre el hecho y la figura. Por tanto, 
(esto es, un "signo proposicional") posee, pese a las apariencias, una auténtica similitud con el hecho que representa; y en virtud de pertenecer a la misma categoría ontológica, hay signos proposicionales y hechos que pueden estar relacionados de tal forma que aquéllos representen a éstos. ${ }^{52}$

Así, tenemos que si $p$ es una figura de $\mathrm{P}$, entonces $p$ es un hecho (aunque claramente uno diferente de P). ${ }^{53}$ Pero surge la cuestión: ¿cuál es la estructura de $p$ ? ¿De qué manera están relacionados los signos elementales de $p$ entre sí cuando $p$ es una figura de P? La respuesta que brinda el TLP a esta cuestión central, y que a estas alturas parece casi evidente, es la siguiente: de la misma manera en que los objetos $\alpha, \beta y \gamma$ se encuentran articulados en $P$. Hechos y figuras, además de compartir una multiplicidad lógica y una idéntica estructura. Esto explica por qué una figura es una entidad por encima de la serie de signos elementales dotados de referencia que la componen -por qué, pese a poseer la misma multiplicidad lógica y los mismos signos elementales, las figuras "Sócrates recuerda a Platón” y "Platón recuerda a Sócrates" corresponden a hechos distintos, o incluso por qué "Sócrates recuerda a Platón" es una figura mientras que "Platón Sócrates recuerda a" no lo es. No es suficiente con correlacionar los objetos $\alpha, \beta$ y $\gamma$ de $\mathrm{P}$ con tres signos elementales $a, b$ y $c$ para así obtener una figura de P; hace falta, además, reproducir en el plano simbólico la estructura particular que $\mathrm{P}$ exhibe. Por consiguiente, podemos afirmar que la esencia de la representación consiste en desplegar o mostrar la estructura de un hecho atómico mediante una figura provista de la adecuada multiplicidad y de la adecuada relación figu-

dado que en el universo tractariano hay únicamente dos tipos de entidades, hechos y objetos, y que los objetos no son aptos para la representación de los hechos, entonces solamente los hechos pueden fungir como tal, esto es, las figuras son hechos. Véase $§ 2.16$.

52 "Sólo los hechos pueden expresar un sentido, un agregado de nombres [i.e. signos elementales] no puede hacerlo" (\$3.142). Y más adelante, Wittgenstein precisa: "Que el signo proposicional es un hecho viene encubierto por la forma habitual de expresión, escrita o impresa. Pues en una proposición impresa, por ejemplo, un signo proposicional no tiene el aspecto de ser esencialmente distinto de una palabra" (§3.143).

${ }^{53}$ Son hechos diferentes, pues sus objetos son diferentes. Los signos elementales no han de confundirse con los objetos que éstos denotan. 
rativa. Tal demostración es posible, según Wittgenstein, en virtud de una relación interna que subsiste entre la figura y el hecho que ésta representa, a saber, la posesión de una forma de figuración en común:

2.15 El que los elementos de la figura se relacionen unos con otros de modo y manera determinados representa que las cosas se relacionan también así unas con otras.

A esta conexión de los elementos de la figura la llamo estructura de la figura, y a la posibilidad de estructura, forma de figuración de la figura.

2.151 La forma de la figuración es la posibilidad de que las cosas se relacionen unas con otras como los elementos de la figura.

2.16 Un hecho, para ser una figura, ha de tener algo en común con lo figurado.

2.17 Lo que una figura debe tener en común con la realidad para poder figurarla a su modo y manera -correcta o erróneamente- es su forma de figuración.

2.171 Una figura puede figurar toda realidad de la que tenga la forma. Una figura espacial todo lo que es espacial, una coloreada, todo lo coloreado, etc.

En el TLP, la forma de figuración (o figurativa) tiene el papel de delimitar las diferentes estructuras entre signos elementales que es posible desplegar mediante figuras dotadas de esa forma $(\$ 2.15, \S 2.151)$, muy a la manera en que la escala cromática delimita el conjunto de todas las muestras particulares de color que alguna vez podremos llegar a producir. En otras palabras, la forma de figuración es la responsable de que ciertas combinaciones de signos elementales puedan constituir una figura, mientras que otras combinaciones no lo puedan hacer. ${ }^{54}$ Por esta razón, la forma de figuración es una propiedad interna de las figuras, una propiedad sin la cual ninguna serie de signos elementales

${ }^{54}$ En este sentido, la forma de figuración tiene todo que ver con los requerimientos sintácticos que pesan sobre los signos elementales. Por tanto, el que la combinación de expresiones "Platón Sócrates recuerda a", por ejemplo, no constituya una figura debe poder explicarse, en última instancia, por el hecho de que tal combinación de signos no corresponde a ninguna estructura de signos contenida en alguna forma de figuración existente. 
puede ser considerada apta para la reproducción, bajo esa forma, de un estado de cosas cualquiera. ${ }^{55}$ Sin embargo, y como la $\$ 2.17$ deja en claro, esta forma es un patrimonio común a las figuras y a los hechos atómicos que éstas reproducen; por tanto, en la medida en que captura las posibilidades estructurales de los hechos y de las figuras (\$2.151), la relación que ambas entidades sostienen en virtud de su identidad de forma no es arbitraria, sino que es una relación interna (a diferencia de la relación figurativa). ${ }^{56}$ Gracias a su mutua identidad de forma de figuración, figuras y hechos atómicos están de tal suerte vinculados entre sí que a cada configuración posible de signos elementales (a cada configuración susceptible de constituir una figura) corresponde una configuración posible de objetos y viceversa: todo lo que una forma de figuración determina como un hecho atómico posible es también apto para ser representado por medio de una figura que posea esa misma forma (§2.171). En este sentido, lo que explica que el espacio (de $n$ dimensiones), por ejemplo, sea considerado por Wittgenstein una forma figurativa (\$2.171), es que el conjunto de las configuraciones $n$-dimensionales posibles de signos elementales coincide con el conjunto de las configuraciones $n$-dimensionales de objetos físicos (o, hablando negativamente, que las limitaciones que aplican a la figuración en $n$ dimensiones son idénticas a aquellas que aplican a la configuración de objetos en un espacio de $n$ dimensiones). Por tanto, una forma figurativa en particular determina o aísla un "campo" de posibles conexiones objetuales de un tipo específico (espaciales, temporales, cromáticas, etc.) que, al ser asimismo un campo de conexiones posibles de signos elementales (pues las posibilidades estructurales de figuras y hechos son

55 "Una propiedad es interna cuando es impensable que su objeto no la posea" ( $\$ 4.123)$.

${ }^{56} \mathrm{Cfr}$. 22.1513 . A este respecto, Anscombe nos dice: "Thus there are two distinct features belonging to a picture [...]: first, the relation between the elements of the picture; and second, the correlations of the elements in the picture with things outside the picture [...]. The correlating is not something the picture does; it is something that we do", en An Introduction to Wittgenstein's Tractatus, 1959, Nueva York, Harper \& Row Publishers, p. 68. Y un poco antes afirmaba: "What I have called the externality of the correlations between the elements of a picture and actual objects is an important feature of Wittgenstein's account. [...] [All] the internal features are supposed to be identical in the proposition (or describing fact) and the described fact", op. cit., p. 67. 
las mismas, si figuras y hechos comparten dicha forma de figuración), condiciona la descripción de cualquier conexión objetual de ese tipo particular. ${ }^{57}$

Naturalmente, dadas la perspectiva y la ambición que subyacen a la Cuestión crucial del TLP, la forma de figuración que concentra todo el interés de Wittgenstein es la forma lógica de figuración. Es así porque la forma lógica, al determinar qué relaciones entre objetos son metafísicamente posibles, determina ipso facto qué relaciones entre signos elementales son significativas (esto es, qué concatenaciones de signos son susceptibles de dar lugar a una figura). ${ }^{58,59,60}$ Dicho de otro modo, la comunidad de forma lógica que prevalece entre el mundo y el lenguaje es aquello que garantiza que, una vez establecida la referencia de los signos elementales de nuestro lenguaje (cosa que depende de nuestras convenciones), quede inmediatamente determinado el conjunto de las figuras en las cuales tales signos pueden aparecer. Pues si es lógicamente imposible que un objeto $\beta$ aparezca en un hecho $\mathrm{P}$ (al no estar contenido $\mathrm{P}$ en la forma de $\beta)^{61}$ entonces, en virtud de la identidad de forma lógica entre $\mathrm{P}$ y su figura $p$, no es posible que, si $b$ denota a $\beta$, $p$ pueda contener a $b$. Por consiguiente, la forma lógica constituye el último garante de la correlación entre el ámbito de lo metafísicamente

${ }^{57}$ La forma de representación es el ancestro del concepto de "gramática" que encontramos en la filosofía de Wittgenstein a partir de finales de los años veinte. A este respecto, consúltese la entrada "form of representation" en H. J. Glock, A Wittgenstein Dictionary, 1996, Malden (MA), Blackwell, pp. 129-35.

58 "[A] sentence reflects the logical form of reality in that all the possible combinations of its constituent symbols represent possible configurations of the corresponding entities in reality, and viceversa, i.e., every possible configuration of these entities must be matched by some possible (correctly formed) combination of symbols", en J. Hintikka y M. B. Hintikka, "Some Remarks on Logical Form", Synthese, vol. 56, 1983, p. 156.

${ }^{59}$ Una figura es apta para representar el conjunto de los hechos posibles con los cuales comparte una forma lógica, tal como la fórmula ' $x \mathrm{R} y$ ' es apta para representar en el contexto de la lógica de primer orden cualquier relación binaria entre objetos (no necesariamente distintos entre sí).

60 “Toda figura es también una figura lógica. En cambio, no toda figura es, por ejemplo, una figura espacial”, $\$ 2.182$.

${ }^{61}$ Cfr. $\$ 2.0123$ : "Si yo conozco un objeto, conozco también todas las completas posibilidades de su ocurrencia en estados de cosas. (Cada una de tales posibilidades debe estar contenida en la naturaleza del objeto.) No se puede hallar más tarde una nueva posibilidad”. 
posible y de lo lingüísticamente articulable. Estas ideas se condensan en las siguientes secciones:

2.18 Lo que toda figura, cualquiera que sea su forma, tiene que tener en común con la realidad para que, en suma, pueda figurarla - correcta o erróneamente-, es la forma lógica, esto es: la forma de la realidad. [...] 2.2 Una figura tiene en común con lo figurado la forma lógica de figuración. [...]

2.203 Una figura contiene la posibilidad de la situación que representa.

Antes de cerrar esta sub-sección, me parece importante conectar los conceptos de "forma lógica de figuración" y "forma lógica de los objetos" que, por propósitos expositivos, hemos abordado separadamente a lo largo de este artículo. Según hemos visto, una figura es capaz de representar un hecho porque, en última instancia, ambas entidades gozan de idénticas posibilidades combinatorias o, lo que es lo mismo, porque el lenguaje (el conjunto de las figuras) posee la forma lógica de la realidad $(\$ 2.18, \S 2.2)$. Sin embargo, el hecho que una figura representa, y que constituye su contenido o su sentido, es un hecho posible, una coordenada en el espacio lógico $(\$ 2.202, \S 3.4)$ que puede o no formar parte del mundo, en tanto acaezca o no acaezca. ${ }^{62}$ Por consiguiente, el contenido de las figuras (esto es, el sentido de nuestras oraciones) depende de la naturaleza lógica de los objetos que ese contenido (ese hecho posible) articula, puesto que como sabemos, cualquier hecho posible se encuentra originalmente prejuzgado en la forma de los objetos que éste articula. En otras palabras, si una figura es susceptible de representar un hecho posible en virtud de que posee la misma forma de figuración de la que goza el hecho reproducido, pues disfruta

${ }^{62}$ Esto indica que el TLP desarrolla un dualismo semántico ligeramente diferente al que Frege defendió en su seminal artículo "Sobre sentido y referencia". Para Frege, cualquier expresión bien formada de un lenguaje natural debía exhibir esta doble dimensión semántica (un sentido y una referencia); para el joven Wittgenstein, en cambio, sólo cabe hablar de sentido si nos restringimos al ámbito de las figuras, y de referencia si nos restringimos al ámbito de los signos elementales o nombres de los que las figuras se componen. $C f r$. $§ 3.144, \S 3.221$ y §3.3. Para referencias de Frege, ver "Sobre sentido y referencia", en G. Frege, Ensayos de semántica y filosofía de la lógica, op. cit., pp. 84-111. 
de las mismas las posibilidades estructurales que el hecho, y si estas posibilidades a su vez dependen de la forma lógica de los objetos que tal hecho articula, entonces es necesario concluir que la forma lógica de una figura depende esencialmente de la forma lógica de los objetos coordinados en su sentido (en el hecho posible que presenta). Ésta es una consecuencia del papel central de los objetos en la metafísica tractariana; después de todo, es su forma lógica la responsable de determinar qué conexiones entre objetos son posibles, lo cual implica-vía la identidad de las posibilidades estructurales que reina entre el plano lingüístico y el metafísico- que la forma lógica de los objetos determina qué conexiones entre signos elementales (qué figuras) son aptas para la representación. Esta relación de determinación se pone de manifiesto si observamos que, en el plano lingüístico, los signos elementales poseen el rol que, en el plano metafísico, poseen los objetos. Pero dado que los signos elementales, como hemos visto, también son objetos, entonces la conclusión se impone: los signos elementales deben presuponer el conjunto de todas las figuras en las cuales éstos pueden aparecer. ${ }^{63}$ Podemos, entonces, hablar con toda propiedad de la forma lógica de un signo elemental $a$, al igual que otrora hablábamos de la forma lógica de un objeto $\alpha$, y con esto queremos dar a entender el conjunto de las concatenaciones de signos elementales significativas que contienen a $a$. Por consiguiente, la forma lógica de las figuras se encuentran subordinadas a la forma lógica de los signos elementales que participan en ellas, del mismo modo en que la forma lógica de un hecho atómico depende, en última instancia, de la forma lógica de los objetos que aparecen en él.

${ }^{63} C f r$. $§ \S 3.31-3.311$ : “A cualquier parte de una proposición que caracterice sus sentido la llamo expresión (símbolo). Una expresión es todo lo que, siendo esencial para el sentido de la proposición, pueden tener en común entre sí las proposiciones. Una expresión caracteriza una forma y un contenido. Una expresión presupone las formas de todas las proposiciones en las que puede ocurrir. Es la marca característica común de una clase de proposiciones". 


\subsection{Verdad y falsedad. Imposibilidad del metalenguaje. \\ El TLP a la luz del TLP}

En nuestro recorrido hemos podido constatar que, según el TLP, el dominio de lo posible se encuentra delimitado por el conjunto de los objetos que el universo contiene. Esto se debe a que la forma lógica de un objeto prejuzga el conjunto de los estados de cosas en los cuales éste puede verse involucrado, razón por la cual, una vez dados todos los objetos del mundo (y junto con ellos todas sus respectivas formas lógicas), queda determinado el espacio de todas las posibles maneras de ser del mundo. Ahora bien, si consideramos que el papel de una figura consiste en mostrar un hecho posible (un hecho que, como sabemos, es su sentido) entonces, si un lenguaje es en esencia un conjunto de concatenaciones de signos apto para la verdad (o para la falsedad), y si cualquier concatenación de signos apta para la verdad es una figura lógica de un hecho posible (como Wittgenstein sostiene en la §4.03), se sigue que un lenguaje como el español debe ser, en un sentido muy amplio, algo mediante lo cual todas las posibles maneras de ser del mundo son representadas. ${ }^{64}$ Pero este conjunto está implícito en los objetos que el mundo contiene (vía sus formas lógicas); por tanto, los objetos en el TLP tienen la función de delimitar el ámbito de lo metafísicamente posible y también la de circunscribir el conjunto de lo expresable por medio de cualquier lenguaje posible.

Por otro lado, en última instancia lo que hace posible que una serie de signos sea apta para la verdad o la falsedad es la identidad de forma lógica que supone esta serie de signos y el hecho posible representado por ella; sin embargo, la verdad o la falsedad mismas de una figura no dependen únicamente de su forma o de su sentido, sino que deben movilizar algún elemento extra, responsable de hacerlas verdaderas o falsas. Esto se puede apreciar si observamos que figuras como "Schopenhauer es optimista" y "Schopenhauer no es optimista", que no pueden tener el mismo valor de verdad, deben tener, según el

64 "Una proposición determina un lugar en el espacio lógico"; "la totalidad de las proposiciones es el lenguaje”, $\S 3.4$ y $\$ 4.001$. 
TLP, el mismo sentido, pues de lo contrario los hechos posibles presentados por ambas figuras no tendrían relación alguna y, en dado caso, no se ve cómo una podría ser la contradictoria de la otra.$^{65}$ Empero, el que figuras contradictorias posean un sentido idéntico no implica, por supuesto, que ambas digan lo mismo acerca de él. Antes bien, lo que una de ellas afirma, a saber, la existencia del hecho SCHOPENHAUER ES OPTIMISTA, la otra lo niega, al afirmar la inexistencia exactamente del mismo hecho; por consiguiente, la relación entre las figuras y el mundo responsable de la verdad (y de la falsedad) atañe a lo que éstas dicen, así como a la polaridad que los hechos posibles mostrados por las figuras poseen en el momento en que se utilizan. Una figura es verdadera si y sólo si la existencia (o inexistencia) que ésta afirma del hecho posible que muestra corresponde con la polaridad que este hecho posee en el momento en que la figura es utilizada, esto es, si y sólo si la figura concuerda con la realidad $(\S 2.06, \S 2.222) .{ }^{66}$

Así, por un lado, el conjunto de las figuras representan exhaustivamente todo lo que el mundo puede ser y, por el otro, el conjunto de las figuras verdaderas (en un momento dado) describe exhaustivamente la manera en que el mundo actualmente es (en ese momento). Pero llegados a este punto es crucial observar lo siguiente: que aquello que siempre se encuentra en el horizonte del fenómeno de la representación lingüística no es otra cosa que el mundo mismo, puesto que no existe (y no puede existir) figura alguna que represente algo que no

${ }^{65} C f r$. $\$ 2.11, \S 2.202, \S 2.221$ y $\$ 4.0621$. En este último aforismo existe, empero, una imprecisión por parte de Wittgenstein. Su última frase reza: "Las proposiciones " $p$ " y " $\sim p$ " tienen sentido opuesto, pero les corresponde una y la misma realidad" (las negritas son mías). No obstante, estrictamente hablando y a la luz de lo afirmado en los aforismos mencionados, esto tiene que ser falso, pues si el sentido de una figura es, como se dice en la \$2.221, "lo que [la] figura representa", y si lo que una figura representa es, según la §2.202, "una situación posible en el espacio lógico" (donde "situación" (Sachlage) es sinónimo de "estado de cosas"), entonces, si a $p$ y a $\sim p$ corresponde "una y la misma realidad" (o mejor, una y la misma posibilidad), su sentido debe ser igualmente idéntico. Por tanto, quizá sería mejor expresar la idea contenida en la última oración de la $\$ 4.0621$ de la siguiente manera: "Las proposiciones " $p$ " y " $\sim p$ " dicen cosas opuestas, pero les corresponde una y la misma realidad".

${ }^{66}$ "Una figura muestra su sentido. Una proposición muestra cómo están las cosas si es verdadera. Y dice que están así” (\$4.022). 
sea, cuando menos, un hecho meramente posible. ${ }^{67} \mathrm{Si}$ consideramos que el mundo es el objeto de estudio primordial de las ciencias naturales, lo anterior equivale a afirmar que el único tipo de discurso genuinamente significativo es el discurso de la ciencia; por consiguiente, el español, o mejor aún, la parcela descriptiva del español (o de cualquier otro lenguaje natural o artificial) debe su expresividad al hecho de que su estructura profunda (y no su estructura superficial o gramatical) coincide con la estructura del lenguaje figurativo que el TLP esboza. Dicho sea de paso, aquí se hace sentir una vez más la influencia que el trabajo de Frege tuvo sobre Wittgenstein durante la composición del TLP. Muy a la manera en que aquél pensó que la labor científica requería de un instrumento que clarificase el contenido de los conceptos utilizados en el frecuentemente opaco lenguaje natural (su Begriffsschrift), ${ }^{68}$ Wittgenstein sostuvo que el lenguaje ordinario se caracteriza por travestir su estructura lógica subyacente, estructura que el lenguaje regimentado delineado en el TLP buscaba hacer explícita y que es responsable, según él, del poder expresivo del lenguaje natural. En sus propias palabras:

4.002 El hombre posee la capacidad de construir lenguajes en los que se pueda expresar cualquier sentido sin tener ni idea de cómo y de qué significa cada palabra. [...]

El lenguaje [ordinario] disfraza el pensamiento. Y lo hace en verdad de tal modo que uno no puede inferir a partir de la forma externa de la vestimenta la forma del pensamiento vestido con ella.

4.1 Las proposiciones representan la existencia o no existencia de estados de cosas.

4.11 La totalidad de las proposiciones verdaderas es la ciencia natural (o la totalidad de las ciencias naturales).

67 "Los límites de mi lenguaje significan los límites de mi mundo", §5.6.

${ }^{68}$ "I believe that I can best make the relation of my ideography to ordinary language clear if I compare it to that which the microscope has to the eye. Because of the range of its possible uses and the versatility with which it can adapt to the most diverse circumstances, the eye is far superior to the microscope. [...] But, as soon as scientific goals demand great sharpness of resolution, the eye proves to be insufficient. The microscope, on the other hand, is perfectly suited to precisely such goals, but that it is why it is useless for others", en Begriffsschrift, A Formula Language, Modeled Upon That of Arithmetic, For Pure Thought, versión electrónica accesible en http://dec59.ruk.cuni.cz/ kolmanv/Begriffsschrift.pdf 
Por tanto, si el TLP está en lo correcto, entonces la esfera de lo expresable coincide con lo que es posible representar mediante los recursos expresivos que las ciencias naturales tienen a su disposición, es decir, con la esfera de lo fáctico. Desde una perspectiva negativa, esto significa que no es posible hablar de aquello que trasciende la esfera de los hechos (posibles o actuales), como por ejemplo de lo que constituye nuestro deber, de la naturaleza de lo bello y, en general, del ámbito entero de los valores; sin embargo, debemos advertir que esta restricción se aplica con igual fuerza a la empresa de describir lo que debe ser el caso para que una concatenación cualquiera de signos vehicule un significado y pueda así ser dicha verdadera o falsa, esto es, al proyecto metalingüístico que anima al TLP.

Suponer lo contrario equivaldría a suponer que es posible representar la forma lógica de la realidad mediante una figura y, por tanto, que la forma lógica es un hecho constitutivo del mundo; sin embargo, en el marco del TLP esta hipótesis es absurda: pues supongamos (para reductio) que $\varphi$ es tal figura, que $\Psi$ es el hecho que $\varphi$ supuestamente representa, y preguntémonos: ¿qué haría posible que, en dado caso, $\varphi$ figurase a $\Psi$ ? Si seguimos a Wittgenstein, sería preciso responder que tal posibilidad dependería de una identidad de forma lógica subsistente entre $\varphi$ y $\Psi$. Pero aquí una importante confusión se hace patente porque, ¿cómo podría $\varphi$ representar aquello mismo que hace posible que $\varphi$ represente algo en absoluto (la forma lógica de la realidad, el hecho que hemos supuesto es $\Psi)$ ? Para lograr esto, $\varphi$ debería situarse por fuera de su propia forma lógica de figuración; pero esto es imposible ya que $\varphi$, al margen de su forma lógica, no puede constituir figura alguna. En este sentido, representar mediante una figura la forma lógica de la realidad es tan factible como representar por medio de una fotografía el espacio que ella misma ocupa. ${ }^{69,70}$ Por consiguiente, nos vemos obli-

${ }^{69}$ En su comentario a la edición castellana del Tractatus que hemos citado, Valdés Villanueva presenta un argumento similar al que desarrollo: "Lo que $[\varphi]$ tendría que tener en común con lo que presumiblemente figurase habría de ser, por así decirlo, la forma lógica de la forma lógica $[\ldots]$ Para que esto sucediera, nuestro signo proposicional $[\varphi]$ tendría que tener la forma de algo que no es un hecho - la forma lógica de la forma lógica-; y esto quería [sic] decir que no sería un hecho, no formaría parte del mundo; a fortiori, no podría haber tal proposición que representase la forma lógica (4.121)”, p. 163.

${ }^{70}$ Otra analogía útil se proporciona en la $§ 5.6331$ : el ojo no se encuentra en su propio campo visual. 
gados a descartar nuestra hipótesis inicial y a reconocer que no puede existir tal $\varphi$, lo cual implica, dada la ecuación de lo metafísicamente posible y lo figurable que el TLP incorpora, que tampoco puede existir tal presunto "hecho lógico" $\Psi$, esto es, que la forma de la realidad supera las capacidades pictóricas de cualquier lenguaje posible, pese a constituir la condición de posibilidad para la existencia de cualquier sistema de representación simbólica. Esto significa que la lógica es trascendental, que la forma lógica común a las figuras y a lo figurado, la forma de la realidad, yace enteramente por fuera del mundo. Wittgenstein dice:

2.174 [Una] figura no puede situarse por fuera de su forma de representación.

4.12 Las proposiciones pueden representar toda la realidad, pero no pueden representar lo que tienen en común con la realidad para poder representarla: la forma lógica.

6.124 Las proposiciones de la lógica describen el armazón del mundo o, más bien, lo representan. No "tratan" sobre nada.

6.13 La lógica no es una teoría, sino una imagen especular del mundo. La lógica es trascendental.

Como podemos apreciar, una de las consecuencias de identificar la esfera de los hechos con la esfera de lo decible es que el TLP debe condenarse a sí mismo al sinsentido al que condena a toda tentativa de articular proposiciones con un contenido diferente del fáctico; por tanto, el valor del TLP no puede residir en lo que éste dice ya que, de acuerdo con los propios estándares del TLP, el TLP no dice realmente nada. Sin embargo, es posible ponderar el esfuerzo de Wittgenstein a la luz de lo que su obra busca mostrar: la imagen de un mundo limitado por el espacio de los hechos, pero cuya proyección supone un punto de vista externo a esta totalidad -el punto de vista de la eternidad-, así como un "lugar" desde el cual este panorama se ofrece -el 'espacio' de lo místico (\$6.45). En este sentido, las ideas desarrolladas en el TLP no constituyen una verdadera teoría filosófica pues, por paradójico que parezca, el TLP no tiene el propósito de avanzar un determinado 
número de figuras acerca de la naturaleza íntima del mundo o al fenómeno del significado; por el contrario, el TLP debe ser visto como una implacable crítica a la tradición filosófica occidental, la cual concibe el trabajo de la filosofía como el de una especialista dedicada a resolver una gama especial de problemas (los "problemas perennes") por medio de la articulación de una serie particular de proposiciones (las filosóficas) y de la explicitación de su contenido mediante métodos deductivos. Esto sería factible, según Wittgenstein, si los filosóficos fuesen genuinos problemas, o lo que es equivalente, problemas susceptibles de ser resueltos gracias a una investigación de orden científico; pero no lo son, muestra de ello es que "aun cuando todas las posibles preguntas científicas hayan obtenido una respuesta, nuestros problemas vitales [i.e. los problemas de la filosofía] ni siquiera se han tocado.” (§6.52). Por consiguiente, la única manera aceptable de hacer filosofía, de acuerdo con el TLP, consiste en hacer manifiesta la fundamental carencia de sentido de los problemas filosóficos y la medida del progreso en filosofía consiste, no en la resolución de sus enigmas, sino en su disolución o desaparición. La filosofía, como el TLP, tiene así la estructura de un kōan: se constituye por un conjunto de problemas que carecen de fondo $y$ de superficie, y de cuya confrontación no es posible obtener un genuino conocimiento sino, en el mejor de los casos, un tipo de experiencia que nos haga manifiesto el orden eterno en el cual se encuentran inmersas todas las cosas.

6.53 El método correcto en filosofía consistiría propiamente en esto: no decir nada más que lo que se puede decir, esto es: proposiciones de la ciencia natural [...]; y entonces, siempre que alguien quisiese decir algo metafísico, demostrarle que no había dado significado alguno a ciertos signos de sus proposiciones.

6.54 Mis proposiciones son elucidaciones de este modo: quien me entiende las reconoce al final como sinsentidos, cuando mediante de ellas -a hombros de ellas- ha logrado auparse por encima de ellas. (Tiene, por así decirlo, que tirar la escalera una vez que se ha encaramado en ella.) 7. De lo que no se puede hablar, hay que callar la boca. 
CITAM Derechos Reservados.

La reproducción total o parcial de este artículo se podrá hacer si el ITAM otorga la autorización previamente por escrito. 


\section{LA ÉPICA GRIEGA ARCAICA (CUÉNTAME ALGO DE HOMERO) \\ Pedro C. Tapia Zúñiga*}

RESUMEN: La poesía épica griega -haya sido como haya sido- es el fundamento, o el principio, de nuestra literatura occidental (no sólo en los cánones épicos, sino también en los dramáticos; que Homero supiera de poesía lírica es lo más natural). Este texto sólo bosqueja una introducción de la épica en la literatura griega y, tras recordar algo de lo que tradicionalmente se cuenta de Homero, reseña lo que se dice de él en los últimos tiempos.

$$
\text { গ্ৰe }
$$

\section{ARCHAIC GREEK EPIC (TELL ME ABOUT HOMER)}

ABSTRACT: Greek epic poetry has always been the foundation or the beginning of Western literature not only in the epic canons, but also in the dramatic ones because Homer's knowledge of lyric poetry was expected. In this article, we will give an introduction of the epic in Greek literature and remember what has been traditionally mentioned about Homer, so that we can reflect on what has been stated about him recently.

PAlabras Clave: Homero, épica griega arcaica, Cilicia, Schrott, Ilíada, Odisea. KEY WORDS: Homer, archaic Greek epic, Cilicia, Schrott, Illiad, Odyssey.

RECEPCIÓN: 31 de octubre de 2014.

APROBACIÓN: 17 de noviembre de 2014

* Centro de Estudios Clásicos, Instituto de Investigaciones Filológicas, UNAM. 
CITAM Derechos Reservados.

La reproducción total o parcial de este artículo se podrá hacer si el ITAM otorga la autorización previamente por escrito. 


\section{LA ÉPICA GRIEGA ARCAICA (CUÉNTAME ALGO DE HOMERO)*}

\section{Intento un bosquejo de los asuntos más} relevantes acerca de Homero y sus obras. Comenzaré afirmando que, de todos los poetas que conocemos, ninguno como Homero ha causado tantos problemas y, a la vez, ha dado tantas satisfacciones. Desde sus orígenes, y hasta nuestros días, Homero y sus obras -sobre todo la Ilíada-, han sido objeto tanto de críticas furiosas como de los encomios más fervientes. Para los amantes de Homero, hablar de la Ilíada y de la Odisea es mantener viva la convicción de la superioridad literaria de esos poemas, es volver sobre su perfección artística, y sobre su autor; sin embargo, después de que ya se ha hablado del divino Homero, del genial vidente, del ciego de Quíos o de Esmirna o de alguna de las siete ciudades que lo reclaman como hijo predilecto; del historiador, del filósofo que con sus epítetos descubrió las esencias de las cosas, del padre de toda filología, de la máxima autoridad en geografía, en religión y en todos los aspectos de la vida habidos y por haber, del padre, poeta y fundador de la literatura occidental, ¿qué más puede decirse?

Comencemos por las críticas, pues éstas aparecieron casi al mismo tiempo que las obras. En el siglo VI antes de Cristo, Jenófanes de Colofón, poeta él mismo, y rapsoda, le reprochó a Homero que sus dioses encarnaran los tipos más ignominiosos y reprobables que hay entre

* Conferencia impartida en la Mesa Plenaria del 21 de octubre del 2014 en el marco del IV Congreso Internacional de Estudios Clásicos en México, celebrado en dicho instituto de Ciudad Universitaria. 
los hombres: ellos son ladrones, adúlteros y mentirosos. Por esos mismos tiempos, Heráclito, consecuente con su $\lambda$ ó os divino, razón del mundo y unidad de los contrarios, se opuso a Homero, lo desterró de los festivales y deseó verlo golpeado con azotes. A principios del siglo IV, también Platón reprueba la teología de Homero y explota contra la tragedia, desterrándola de su república; con ello, también desterraba a Homero, a pesar de que al final lo califica como el máximo poeta y el primero de los trágicos. Las críticas y los encomios de las obras de Homero podrían ser objeto de "un gran libro" en el cual podríamos leer, entre miles de cosas, que los encomios y las críticas se acentuaron con la aparición de la Eneida de Virgilio, y con la cuestión de "quién de esos dos genios es el príncipe de los poetas". Y valga apuntar que, durante siglos, el príncipe fue Virgilio, un poeta con rostro, con patria y con sus fechas de nacimiento y de muerte, al contrario de Homero: un ser sin rostro, sin patria y sin fechas: por los mismos tiempos en que aparecen en Grecia sus poemas, Homero desaparece, y nadie sabe quién era ni de dónde venía.

Ahora bien, así como muchas críticas fueron casi perversas y destructivas, muchas otras fueron sanas, basadas en ese insaciable deseo humano de perfección. Por ejemplo, la filología alejandrina, afanada en "reponer" el texto de los poemas de Homero, en general los consideró bien logrados y grandiosos, al grado de que, si algo de dichos textos no le parecía digno de la perfección homérica, recurriendo a la athétesis, lo suprimía, o recurría a la declaración de la "no autenticidad" de tal o cual pasaje; es decir, a la declaración de que, merced a ciertos inconvenientes de fondo o de forma, ese pasaje no era de Homero, porque Homero es perfecto. Es famosa la declaración de Aristarco de Samotracia, quien asentó que la Odisea terminaba en el verso 296 del Libro XXIII, declarando como no auténtico el resto de dicho Libro y todo el XXIV; del mismo modo, también Aristónico declaró como no auténtico, por indecoroso y adúltero, el lance amoroso de Ares con Afroditas ( $c f r$. Od. VIII, versos 266-369).

Puede verse el mismo deseo de perfección en el comentario del verso 359 del Arte poética de Horacio, que, en traducción del doctor Herrera, dice así: "y yo mismo me indigno siempre que el buen Homero dormita". Y puesto que este poeta romano sigue a Calímaco en otras 
partes, cabe pensar que también aquí tiene en la mente los eruditos versos del alejandrino quien, al final del Himno a Apolo cuenta y canta entre la admiración y la crítica, refiriéndose a Homero: "Grande es el flujo del asirio río, pero muchas / inmundicias de tierra y mucha hez arrastra en el agua". Es posible que Calímaco, sutil y breve como acostumbra ser, también quería decirnos que, si queremos saber algo más de Homero, debemos ir a Asiria.

Quizá uno de los ataques más duros fue el que lanzó en 1795 Friedrich August Wolf en sus Prolegomena ad Homerum. Lo que se puso en tela de juicio en tiempos de Wolf era la antigua convicción de la grandeza literaria de los poemas homéricos, de la Ilíada, para ser más precisos; se dijo que este poema no tiene unidad o, mejor dicho, que su precaria unidad procede de un montaje de diversas partes, hecho por uno o varios autores o redactores de talento y aptitud muy discutible, distintos de Homero, el autor de un poema original que debió ser pequeño. La tesis de Wolf se basa en datos o en lugares comunes de su tiempo, y de tiempos anteriores a él: dado que en los siglos de Homero no se conocía la escritura, él era un poeta que improvisaba, era un aedo, no el escritor de una obra literaria como la Ilíada; que siendo un aedo, cantaba en diversos lugares y bajo diversas circunstancias, y sus cantos no podían tener una forma única; que, condicionado por la memoria, era imposible que se supiera así, de memoria, un poema tan extenso como la Ilíada, que debe ser el producto de un tiempo más cercano a nosotros, de uno que ya disponía de la escritura. En resumen, que Homero era el representante de la poesía oral. A Wolf y a los de su escuela se les conoce como "analistas". Se trataba, repitiendo un poco, de un análisis que distinguiera al Homero antiguo, de los nuevos y malos Homeros, y a la breve y buena Ilíada original, de sus incrustaciones recientes, no auténticas y mal logradas. Contra los analistas alzaron su voz los unitaristas, para defender la unidad del poema y la idea de una única persona llamada Homero. Quizá valió que sólo 32 años después de Wolf, en 1827, Goethe, analista él mismo, más poeta que filólogo, tras dudar y sopesar los pros y los contras, dejó oír su voz sobre dichas tesis y dijo: "Wolf destruyó a Homero; sin embargo, no pudo hacerle nada a su poema". 
Tras siglo y medio de jaloneos, hacia mediados del siglo XX podía decirse que ya ni el más riguroso de los analistas creía en una colección mecánica de canciones independientes, y que, a su vez, ningún unitarista negaba la posterior inserción de ciertas partes en ese todo que interpretaban como una unidad. Dejemos la "cuestión homérica", no sin anotar que en 1997, Frank Turner la describió como "una pura invención decimonónica, creada por el atrevimiento filológico alemán, por los conceptos románticos de composición y por el historicismo propio de la época", y recordemos que la Ilíada y la Odisea son los poemas "nacionales" de los griegos, y que están colocados al principio de la literatura occidental bajo el rubro de épica arcaica.

Hablar de poesía épica implica, aunque no se quiera, hacer referencia a otros géneros poéticos, al de la lírica y al de la dramática; para lo que nos interesa, haciendo a un lado los actuales contenidos de dichos géneros, volvamos a la Poética de Aristóteles y recordemos que, en dicho libro, el autor nunca define la poesía, y jamás se ocupa de la "lírica". Nuestras historias de la literatura comienzan con la épica y, como ciertos tratados griegos y latinos comienzan con Zeus, así la literatura griega comienza con Homero, el artesano del č $\pi$ os, de la palabra: la épica es

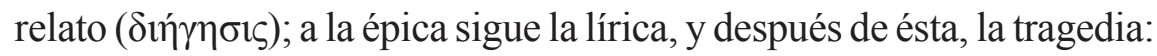
la dramática es acción $(\delta \rho \tilde{\alpha} \mu \alpha)$. Que en la dramática haya relatos, y que en la épica se encuentren dramas, es lo más natural, como es un hecho que tanto en la dramática como en la épica se presentan soplos líricos.

¿Qué diría Aristóteles, si viera este ordenamiento? En su Poética, estudia primero y muy extensamente la dramática, y después, con base en la dramática, y brevemente, se dedica a la épica. A la luz de estos hechos, la opinión de Aristóteles parece clara, si recordamos que al final de su libro, tras preguntarse cuál de esos dos géneros es la forma más elevada, él se responde que poéticamente es una cuestión muy difícil, diaporética, pero que él se inclina por la superioridad de la tragedia. ¿Y la lírica? Para Aristóteles, lo que no es épica ni dramática, pertenece a otros géneros, a otras especies de la poética; por ejemplo, a la ditirámbica, a la aulética y a la citarística, o a otras especies que se sirven únicamente de la palabra y no tienen nombre específico, como la dística 
(o elegíaca) y la yámbica, géneros poéticos que se distinguían mediante criterios rítmicos y de contenido.

Que nuestras historias de la literatura comiencen con Homero resulta natural, si se acepta que Homero es anterior a Hesíodo, y que lo primero que se escrituró, por razones políticas, fue la épica, representante de toda una tradición oral cultivada por aedos, que mediante fórmulas y versos, improvisaban la sabiduría y los tesoros griegos dignos de relato. Sin embargo, a estas alturas, uno puede preguntarse sanamente si es válido seguir repitiendo que la épica homérica es el principio de la literatura occidental, impecable y digna de los calificativos más grandiosos, y seguir creyendo en que Homero es un genio sin rostro y sin patria, y el más viejo de los poetas de que tenemos noticia, uno que, como los viejos aedos, improvisaba repitiendo cada vez lo mismo, aunque variando cada vez un poco, de acuerdo con los oyentes.

En 1967, el profesor Albrecht Dihle, viendo el aislamiento en que desde los siglos XV y XVI se encuentran las obras de la literatura griega con respecto a los adelantos de otras ciencias, apuntaba que, merced a la canonización de la literatura grecolatina hecha por los renacentistas, tendemos a aislar las obras magistrales de esa literatura, y a verlas básicamente como testimonios de postulados estéticos y morales que hay que reconocer como obligatorios; decía que, bajo esos presupuestos, las condiciones históricas en que surgieron dichas obras tal vez son interesantes, pero no importantes para la valoración de las mismas. Más o menos literalmente, Albrecht Dihle termina sus reflexiones de la siguiente manera: "Un nuevo camino hacia los fundamentos de nuestra civilización sólo puede abrirse a quien formule sus preguntas tomando en serio la tradición, y luego, con base en los nuevos conocimientos científicos, esté dispuesto a corregir o a modificar sus valoraciones tradicionales, es decir, a quien no descuide las posibilidades que tiene el intelecto de liberarse de pautas tradicionales, o de relativizar la validez de las mismas".

De 1967 a la fecha han pasado muchas cosas; volvamos a la épica y preguntemos, primero, si es ésta, sin más, el principio de la literatura occidental; luego, qué sabemos sobre Troya y Homero, y, finalmente, 
qué se dice hoy sobre la patria de Homero. En el New Companion to Homer de 1997, los editores apuntaban "el amplio desplazamiento en los intereses de los eruditos en la última generación (o en las dos últimas), ellos se alejan de las formas tradicionales del análisis histórico y se dirigen hacia cuestiones más ampliamente culturales. Los análisis históricos y arqueológicos siguen siendo importantes, pero ya no proporcionan un amplio marco de referencia de los estudios homéricos". Hay que decir que este apunte es válido, pero vale tomar en cuenta algunas de las pocas cosas que tienen que ver con historia y arqueología.

Que Homero y su épica sean el principio de la literatura occidental puede afirmarse, con tal que aceptemos que el adjetivo "arcaico", de à $\chi \eta ́$, sólo remite a un principio, ese del que tenemos noticia documentada por escrito, y no confundamos lo arcaico con las ideas de primitivo, verde, imperfecto y torpe, que suelen asociarse a dicho término: si algo, con sus bemoles, es característico de la literatura arcaica, es su perfección técnica. Que la épica homérica sea el principio de la literatura occidental depende también de qué tanto nos sentimos occidentalmente distintos de las culturas del Medio Oriente: desde hace tiempo se acepta que la astronomía nos viene de Oriente, que la medicina nos llegó de Oriente, que las matemáticas las aprendimos de Oriente, que mucha filosofía griega procede de Oriente y que la escritura es legado de Oriente; en síntesis, que en técnica, religión y arte, la cultura griega tomó muchísimos elementos de Oriente. Que, como dice el profesor Szlezák en su Homero de 2012, "hasta hoy no sepamos por qué camino y mediante qué mediación lingüística llegó a Grecia desde Mesopotamia esta riqueza literaria", no significa, como quiere el mismo Szlezák, "que los griegos no eran conscientes de la amplísima participación de los orientales en su herencia literaria". No es gracioso asumir que los griegos hayan sido tan ingenuos, ni que hayan sido unos plagiarios de los orientales; más bien cabe pensar que, para ellos, sus fuentes eran tan evidentes que no necesitaban citarlas; o que, entre ellos, aún no existía esa tajante distinción entre Oriente y Occidente, y que ellos, igual que los orientales, desde los antiguos tiempos micénicos, iban y venían de Oriente a Poniente, y cabe afirmar que unos y otros se sentían en todos lados como en su propia casa. 
Ese antagonismo entre Oriente y Occidente surgió hacia finales del siglo VI y principios del V. Raoul Schrott recuerda este antagonismo en los siguientes términos: "sólo después de las guerras persas, Oriente y Occidente se convirtieron en dos mundos distintos que, como opuestos, no pueden existir: allá, los orientales, afeminados y esclavos del lujo, despóticos y polígamos; acá, los griegos, duramente puestos a prueba, acerados por un árido y miserable entorno, liberales y democráticos". Antes no era así; en 1966, en los "Prolegómenos" a su edición de la Teogonía de Hesíodo, el profesor West concluía: "las grandes civilizaciones están en el Oriente, y desde el principio, el rostro de Grecia estuvo vuelto hacia el sol. Grecia es parte de Asia; la literatura griega es literatura del cercano Oriente".

Cabe, finalmente, aceptar que Homero es el principio de la literatura occidental, siempre y cuando aceptemos que hablar de su anterioridad con respecto a Hesíodo, sólo puede significar prioridad cualitativa; es decir, sus obras y sus versos son poéticamente superiores, pero temporalmente posteriores con respecto a las obras y a los versos de Hesíodo. No debía extrañarnos que Hesíodo cronológicamente sea anterior a Homero, si recordamos, por una parte, que así está escrito en casi toda la tradición griega, que recuerda a sus viejos poetas, en este orden: Orfeo, Museo, Hesíodo y Homero; piénsese en Platón y en Heródoto, por citar unos ejemplos. West, en sus "Prolegómenos", argumentando el terminus post quem de las obras de Hesído, remata el asunto con las siguientes palabras: "que Hesíodo es más viejo que Homero no es ningún punto de vista revolucionario, [ya lo afirmó así en 1914 nada menos que Bethe, el distinguido erudito homérico], y valdría la pena recordar que hasta finales del siglo IV antes de Cristo, la prioridad de Hesíodo fue ampliamente aceptada". No sabemos si Homero leyó los versos de Hesíodo, aunque, dada la erudición que muestra en sus poemas, cabría pensar que no sólo leyó, sino que incluso estudió dichos versos, aprendió de ellos y perfeccionó la técnica del hexámetro, de la misma manera en que, después, perfeccionaría la técnica narrativa épica usada en la Ilíada, para ofrecer una Odisea contra cuya unidad y armonía hay muy poco, o nada que decir. 
Pasando a la segunda cuestión: ¿qué puede uno decir sobre Homero y su Troya? Valga recordar solamente el fuit Troia, expresión preñada con que los latinos querían decir "existió Troya, pero ya no existe". Gramaticalmente, la palabra Troía es el femenino del adjetivo Troios (Tpóïos, $\alpha$, ov). Sin embargo, con frecuencia, Homero sustantiva el fe-

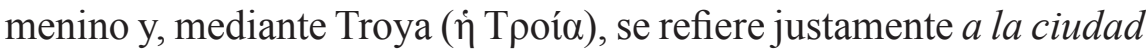
de la región troya, es decir, a la ciudad que normalmente llama Ilión. En la Odisea, Homero habla de Troya 25 veces, y unas 50 veces en la Ilíada; en algunos de estos versos puede haber duda de si, mediante "Troya", se refiere a la ciudad o a la región; sin embargo, hay lugares en donde la referencia a la ciudad es innegable; por ejemplo, cuando en la Odisea (1.2) habla de "saquear el sagrado castillo de Troya", o cuando en la Ilíada (2.141) dice "Troya de amplias calles", o, para que no haya dudas, cuando tanto en la Ilíada (1.129) como en la Odisea (11.510) habla li-

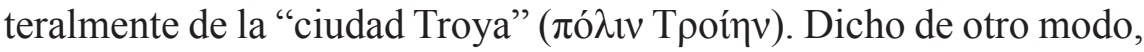
Ilión es el nombre propio de la ciudad; Troya es la ciudad de los troyanos. Por eso, cuando se habla de "Troya y Homero" se hace referencia a la ciudad de los troyanos, esa a la que Homero nombra unas 100 veces en la Ilíada con su nombre propio de "Ilión".

No vamos a hablar de la Troya prehistórica que se remonta al tercer milenio antes de Cristo, esa Troya que hacia el año 1200 antes de Cristo fue la homérica, según los cronógrafos alejandrinos; ni de la Troya ubicada a 4.5 kilómetros de los Dardanelos, donde en 1873 los trabajos arqueológicos de Schliemann encontraron el "tesoro de Príamo"; ni de los posteriores descubrimientos de Dörpfeld, que se extienden hasta 1894 y dividen Troya en IX estratos de los cuales el VI, es decir, Troya VI, es la Troya micénica, y Troya VII, la homérica. Tampoco hablaremos de los trabajos de la Universidad de Cincinatti bajo la dirección de Blegen; ni de las conjeturas y deducciones del profesor Latacz. Todos esos trabajos son dignos de estudio y de encomio, pero no nos sacan la espina de la duda que nos echa en cara la terca realidad: no hay coincidencia topográfica ni arqueológica entre esta Troya y su llanura con la llanura y la Troya de la Ilíada de Homero.

Ya a finales del siglo I antes de Cristo, el geógrafo Estrabón dudaba de la identidad de la Troya de que hablamos con la Ilión de Homero, y 
con buenos argumentos. Estrabón habla de la Tróade y de Ilión en el Libro XIII de su Geografía, y parece pedir perdón por lo que va a afirmar con base en sus descripciones, a saber, "esta [Ilión] no parece ser

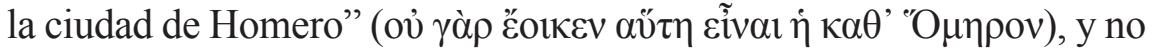
lo es, a pesar de que sus habitantes lo presuman y lo argumenten con base en el poema de Homero; a pesar de que, como cuentan los historiadores, Alejandro Magno, tras su victoria de Gránico, pasó a Ilión, visitó el santuario de Atenea, lo adornó con ofrendas, dio a la aldea el título de ciudad y le prometió infinitos honores.

Dicha controversia llegó a nuestros tiempos, pero desde el siglo pasado ya no se duda de si hay correspondencia entre la Troya de Hisarlik y la Troya de Homero: no hay correspondencia. Lo que se discute es si la discrepancia en la descripción de Troya se debe a que Homero sólo hacía un poema, y no tenía por qué ceñirse a realidades históricas, y si, dado el caso, pudo sacarse de la manga una epopeya tan grandiosa como la Ilíada. En 1974, el profesor Erns Meyer hizo un análisis del asunto y concluyó con lo que parece un resumen de esta cuestión: "los datos que da Homero llevan claramente a la llanura inferior del Escamandro, donde no hay un asentamiento prehistórico tan significativo como Hisarlik; sin embargo, la pormenorizada descripción homérica de Troya no coincide, para nada, con las ruinas de Hisarlik. No tiene sentido querer descubrir en las ruinas los puntos concretos de esta descripción que sólo obedece a la forma poética. Las ruinas no aportan nada para la cuestión de la historicidad de la guerra de Troya".

En tal forma, o aceptamos que es poco probable que una leyenda como la de la guerra de Troya haya sido inventada gratuitamente, $\mathrm{y}$, entonces, nos damos a la búsqueda de algo que se parezca más a lo que describe Homero, o bien aceptamos que Troya es pura invención poética, $\mathrm{y}$, entonces, podemos imaginarla en cualquier otra parte. Sin embargo, puesto que debemos estar dispuestos a corregir o a modificar valoraciones tradicionales, apuntemos algo sobre la tercera pregunta, el último tema de estas líneas, el que nos lleva a lo que en 2009 fue reseñado por el escritor y periodista Wolfgang Büscher como "un pequeño milagro alemán, realizado por Raoul Schrott”. Publicado en 2008, el libro de Schrott se llama Homers Heimat, y lleva como subtítulo Der Kampf um Troia 
und seine realen Hintergründe. La reseña de Büscher es entusiasta hasta el delirio, y exultante hasta lo provocativo. Por si esto pareciera algo exagerado, transcribo algunos de sus apuntes: "'Schrott] escribió el libroescándalo de la estación: un escándalo para las autoridades, para los profesores y para los clasicistas. Es una revisión total [de la Ilíada]". "Lo que Schrott expone acerca del padre fundador de Occidente debía hacer rabiar a los estudiosos de filología clásica, a los estudiosos de historia antigua y a los amigos de Schliemann. Schrott les dice: '¡todo es falso!' Vuestro gran griego no era tal. Ya no busquéis a Homero en la Grecia jónica: él vivió en Cilicia, en el actual recodo de Turquía que da hacia Siria, en donde en otro tiempo se mezclaban pueblos, mitos y antiguas y nuevas culturas dotadas de escritura. Allí él, un escriba probablemente al servicio de los asirios, compuso su Ilíada a partir de leyendas griegas y de epopeyas orientales antiguas escritas en tablillas de barro. Y también podéis olvidaros de Heinrich Schliemann y de su Troya de los Dardanelos. La guerra de Troya también tuvo lugar en Cilicia". Etcétera.

Más allá del delirio y de posibles provocaciones, es necesario invitar al estudio de la tesis de Schrott, una antología de historia, arqueología y topografía. Schrott invita al diálogo y a la discusión de su tesis, para la cual reunió y expuso los documentos que la apoyan; "a partir de ya" dice, "pueden refutarla e incluso hacerla pedazos". Y algo de eso ha sucedido; no ha faltado quien hable de "una tesis llena de fantasías dignas de admiración", o de "especulaciones hechas con tanta ligereza, que uno sólo puede pasmarse o quedarse asombrado", o de "un poema donde las fronteras entre la ficción y la realidad se esfuman al grado de que no pueden reconocerse". Desde luego, cabe no estar de acuerdo con la tesis, pero sería bueno ver las razones del desacuerdo. Al contrario, cabe estar de acuerdo con las severas críticas a la traducción de Schrott, basadas - dicen- en su deficiente formación en filología clásica; sin embargo, no habría que confundir la traducción con sus investigaciones sobre Homero y la Ilíada.

Aquí cabría recordar lo que en 1962 decía George Steiner, hablando de Homero, del Nuevo testamento y de Shakespeare: "Los profesionales están asediados por un hecho curioso: en cada uno de esos tres 
preeminentes enigmas de la crítica literaria e histórica, los que han hecho los descubrimientos más brillantes y decisivos han sido precisamente los profanos". Curiosamente, unos días después de la presentación del libro, el gran Burkert decía: "no pienso que el libro del señor Schrott sea puro desatino. Sin embargo, no creo que la ciencia de la especialidad acepte sus conclusiones". Vayamos a estas conclusiones.

Casi al principio del libro, hay un párrafo que uno puede glosar, extrayendo las premisas de su tesis: 1) a pesar de su dicción, que se remonta a una tradición oral, la Ilíada se evidencia progresivamente como un texto, cuya composición fue acuñada por una redacción hecha básicamente por escrito; 2) los versos dejan ver que la Ilíada se basa en otros textos: en ella emergen paralelos del Gilgamesh que, más que un eco de arquetipos temáticos, suenan como adopciones literales, y 3) al lado de la literatura secundaria del Gilgamesh y otras epopeyas acadias, se evidencian como modelos otros materiales y motivos semíticos e hitita-hurritas, que llevan a la gran cuestión: ¿cómo y dónde llegó un poeta griego a esas fuentes?

Schrott parece avanzar de lo más conocido a lo menos admitido. En la primera premisa recuerda lo que todos sabemos, que en la Ilíada hay mucha tradición oral, pero agrega que la Ilíada no es una simple recopilación de cantos y cuentos que circulaban oralmente, sino que ella fue escrita como cualquier otro libro: Homero la escribió con su puño y letra, sobre papiros o tablillas, de principio a fin, con todos sus libros. No hablemos de la poesía oral; recordemos que el imaginar a Homero escribiendo como cualquier poeta, ya había sido sospechado por Cantarella en su Literatura griega clásica de 1967, en los siguientes términos: "si ya unos siglos antes de Homero se escribieron los poemas babilonios e hititas; si la arcilla fue usada en Cnosos, en Pilos y en Micenas para los documentos en escritura lineal Ay B; si desde el tercer milenio antes de Cristo los egipcios escribían en papiro, y el uso de la escritura está testimoniado en Creta, entonces nada impide creer -y la razón de la poesía también lo requiere- que los poemas homéricos, desde su composición, se hayan fijado mediante la escritura".

En cuanto a la segunda premisa, que la Ilíada se basa en otros textos, e incluye paralelos del Gilgamesh, que suenan como adopciones literales, 
ya lo había asentado Petriconi en 1964 en su artículo “Das GilgameschEpos als Vorbild der Ilias". En su análisis de la muerte de los héroes Gilgamesh y Aquiles, precedida por la misma suerte de sus respectivos amigos, Enkidú y Patroclo, llorados amargamente, Petriconi tenía a la vista los Estudios homéricos de Schadewaldt (1938), en los cuales se conjetura que el héroe Memnón posiblemente es un reflejo del reino asirio, y que la muerte de Patroclo es una "pura y libre invención" de Homero. Petriconi anota un tanto irónicamente: "En sus conjeturas sobre Memnón, Schadewaldt va casi hasta los confines del imperio de los asirios. Si hubiera dado un paso más, y con sólo 50 centavos se hubiera comprado un ejemplar del Gilgamesh, habría tenido en sus manos la clave para una interpretación objetiva de la Ilíada: punto por punto, hay coincidencia entre la muerte de Patroclo y la de Enkidú”. Y, más en serio, Petriconi termina con una reflexión que puede hacernos pensar: "Los tiempos de una filología 'clásica' única ya pasaron; escribir sobre la literatura griega sin saber algo de la asiática del cercano Oriente, se ha vuelto algo tan imposible, como, por ejemplo, estudiar la literatura latina sin conocimientos de la griega".

Tras esas dos premisas, más o menos ya conocidas, Schrott nos recuerda que, al lado de la literatura secundaria del Gilgamesh y de otras epopeyas acadias, en la Ilíada se evidencian materiales y temas semíticos e hitita-hurritas; también eso ya se sabía o, al menos, se conjeturaba; el mismo Petriconi decía: "hay que suponer que Homero conoció la literatura asiática del cercano Oriente, pues lo que justamente se le concede al beocio Hesíodo, forzosamente debe otorgársele al poeta de Quíos". La tesis de Schrott podría plantearse en los siguientes términos: si se pregunta dónde y cómo un poeta griego tuvo acceso a esas fuentes, preguntémonos por la patria de Homero. Curiosamente, Schrott llega a la patria de Homero sólo marginalmente; lo que le importa son los trasfondos reales de la guerra de Troya. Schrott, pues, se adhiere a los que no creen que dicha guerra haya sido pura ficción. De otro modo, si está claro que la Troya "histórica" no es la Troya que describe Homero, ésta, o algo de ésta, debe existir en algún otro lugar.

Ya oímos algo de su tesis: la Troya de Homero está en Cilicia, la región rodeada por las sierras del Tauro y del Amano. Por allí, hacia el Este, 
se ubican históricamente otros "aqueos", a quienes los fenicios llamaban "dánaos", y Homero, dándole un tinte de modernidad a su poema, también los llama "argivos", de Argos, que cobró importancia a partir del siglo VIII y fundó colonias en Oriente. La Ilíada es una compilación de fuentes literarias del cercano Oriente e inscripciones asirias que describen, entre otras caídas, la de Babilonia: Homero proyectó esos materiales sobre la ya existente épica griega de la guerra de Troya, y le incrustó las revueltas de los cilicios contra los asirios; éstos son los aqueos, dánaos y argivos; aquéllos, los troyanos. Homero traslada hacia Cilicia los planos topográficos del mito troyano: allí es real la ancha llanura de Troya, y al Escamandro le da las características que responden al río Píramos; allí están, en Karatepe, sobre una colina de 225 metros de altura, las ruinas de algo muy semejante a la Troya de Homero: una fortificación provista de gruesas murallas y muchas torres de defensa, descrita como "sagrada corona de almenas"; aquí pueden verse las ruinas de las dos y únicas puertas de Troya, la del Norte (que, igual que las “puertas Esceas", da hacia el río), y la del Sur (que respondería a las puertas dardanias); aquí, adentro, hacia el Sur, están, de 55 metros de largo por 45 de ancho, las ruinas del castillo de Príamo, tal como lo describe la Ilíada: con cincuenta tálamos, unos al lado de otros, para sus hijos y sus respectivas esposas, y diez más, del otro lado, para sus yernos; por allí pueden ubicarse colinas que responden a la de Calicolona y a la de la "saltadora Mirina", y aquí, finalmente, en el libro de Schrott, puede verse la documentación pertinente, una documentación temática, arqueológica y topográfica que, si no convence a todos, sin duda invita al estudio y a la discusión.

Por allí, en Cilicia, pudo haber vivido Homero, un hombre de varios reinos; quizá era un cilicio al servicio de la cancillería asiria, tal vez, como hoy vemos por todas partes, alguien con dos nacionalidades. Sólo cabe hablar de "quizá, tal vez, probablemente". Lo importante es que así pueden explicarse sus conocimientos mitológicos y geográficos, y toda la sabiduría oriental que despliega en la Ilíada, escrita hacia el 660 antes de Cristo. En un apartado casi perdido, "Un retrato de Homero, totalmente especulativo", Schrott escribe lo siguiente: "Tal vez-y 
claro, esto es ahora pura especulación- tal vez, únicamente su madre era griega. Su padre quizás era un mesopotamio, uno que llegó a Cilicia en el transcurso de la política asiria de asentamientos, un arameo o un fenicio, más probablemente, quizá, un luvio - contra lo cual habla ese resentimiento que a veces se percibe en la Iliada en contra de los tardíos hititas, es decir, contra los troyanos. Y, para seguir con este juego, digamos que, de acuerdo con la ambiciosa temática de la Ilíada, quizá Homero era todavía un tanto ingenuo al escribirla; en efecto, desde el punto de vista narrativo, la Odisea se ve mucho más compacta y equilibrada. El carácter multifacético de la Ilíada, que se desborda aquí y allá, y en algunos lugares resulta inabarcable con la vista, se presenta como la típica opera prima de un escritor ambicioso que, en su idealismo juvenil, por principio, también presenta con desprecio toda riqueza: entre más oro alguien tiene en la Ilíada, con tanto mayor placer sarcástico Homero le describe su muerte".

En síntesis, la tesis de Schrott sobre los verdaderos trasfondos de la guerra de Troya deja ver trasfondos reales, históricos, geográficos y arqueológicos; sin embargo, son los especialistas quienes pueden y deben juzgar y hablar de acuerdo con las reglas de sus disciplinas;

112 mientras no sea así, vale repetir lo que decía Catalin Pavel en 2011: "entre menos sabe uno acerca de la Ilíada, tanto más fascinantes resultan los argumentos de Schrott". Debemos, pues, estar atentos a los resultados, y dispuestos a liberarnos de pautas tradicionales, o a relativizar la validez de las mismas. Suponiendo que Troya cambie de domicilio, no tenemos que creer lo que, curiosamente, acaba de afirmar el profesor Burkert hablando de la Odisea, a saber, "que ganamos certezas, pero perdemos poesía". Al contrario, sus poemas ganarán dimensión histórica, sin perder nada de su aureola poética; comprenderemos y admiraremos más las reglas de su arte y de sus relatos, y sus comparaciones, descripciones e informaciones frecuentemente envueltas en fórmulas que, sin duda, reformuló y adaptó al hexámetro, nos dirán mucho más de lo que nos habían dicho hasta ahora. 


\section{Bibliografía de referencia}

Aristóteles, Poética, 2000, México, UnAm, Bibliotheca Scriptorum Graecorum et Romanorum Mexicana, introducción, versión y notas de Juan David García Bacca, 2a. edición.

Austin, Norman, “Was Homer a Poet?", Arion, IX, 1, 2007, pp. 104-137.

BETHE, Erich, Homer, Dichtung und Sage, 1914 (2. Auflage, 1929), Leipzig und Berlin, B. G. Teubner, Zweiter Band: I. Teil, Odyssee; II. Teil, Kyklos, Zeitbestimmung, Nebst den resten des troischen Kyklos.

BlanK, Thomas, "Homers Heimat ist die Dichtung (Essay anstatt einer Rezension zu Raoul Schrott: Homers Heimat)", Gymnasium, 115, 2009, pp. 469-474.

BocChetTI, Carla, "La geografía de la Ilíada: una perspectiva cultural”, Nova Tellus (anuario del Centro de Estudios Clásicos), Supplementum III, 2011. BURKERT, Walter, "Das hunderttorige Theben und die Datierung der Ilias", Wiener-Studien, 89, 1976, pp. 5-21.

, Die orientalisierende Epoche in der griechischen Religion und Literatur, 1984, Heidelberg, Carl Winter (Sitzungsberichte der Heidelberger Akademie der Wissenschaften, Philosophisch-historische Klasse, 1984, 1). De Homero a los Magos (la tradición oriental en la cultura griega), 2002, Barcelona, Acantilado, traducción de Xavier Riu.

, Die Griechen und der Orient. Von Homer bis zu den Magiern, 2003

(3. Auflage, 2009), München, Verlag C. H. Beck.

"The Worlds of Odysseus", en Joan Aruz et al. (eds.), ASSYRIA TO

IBERIA at the Dawn of the Classical Age, 2014, New York, The Metropolitan Museum of Art, pp. 255-257.

BÜSCHER, Wolfgang, "Homer und sein Nachdichter", <http://www.zeit.de/2008/ 17/L-Schrott> (25 jun. 2014), reseña a Raoul Schrott, Homers Heimat. Der Kampf um Troia und seine realen Hintergründe, 2008.

CANTARELlA, Raffaele, La letteratura greca classica, 1967, Milano, SansoniAccademia.

DIHLE, Albrecht, Griechische Literaturgeschichte, 1967, Stuttgart, Alfred Kröner Verlag (Kröners Taschenausgabe, Band 199).

DRÄGER, Paul, "Homers Heimat, Der Kampf um Troia und seine realen Hintergründe, München, Carl Hanser Verlag” (reseña), Bryn Mawr Classical Review 2009.08, <http://bmcr.brynmawr.edu/2009/2009-08-30.html> (19 septiembre 2014). 
FINKEL, Irving, "Ashurbanipal's Library at Niniveh", en Joan Aruz et al. (eds.), ASSYRIA TO IBERIA at the Dawn of the Classical Age, 2014, New York, The Metropolitan Museum of Art, pp. pp.68-69.

GILGAMESH o la angustia por la muerte (poema babilonio), 2000, México, El Colegio de México, Centro de estudios de Asia y África, 4. ed., traducción directa del acadio, introducción y notas de Jorge Silva Castillo.

Görgemanns, Herwig (Hrsg.), Die griechische Literatur in Text und Darstellung, 1991, Stuttgart, Philipp Reclam, Band 1 ARCHAISCHE PERIODE, herausgegeben von Joachim Latacz.

HAAG, Herbert, Homer, Ugarit und das Alte Testament, 1962, Einsiedeln Zürich Köln, Benziger Verlag (Biblische Beiträge, Neue Folge, Heft 2).

HESIOD, Theogony, 1966, Oxford, Clarendon Press, edited with Prolegomena and Commentary by Martin Litchfield West.

HÖHFELD, Volker (Hrsg.), Stadt und Landschaft Homers (ein historisch-geografischer Führer für Troia und Umgebung), 2009, Mainz, Verlag Philipp von Zabern.

HOMER, Ilias, 2008, München, Carl Hanser Verlag, übertragen von Raoul Schrott, kommentiert von Peter Mauritsch.

Homero, Ilíada, 1996, México, UnAM, Bibliotheca Scriptorum Graecorum et Romanorum Mexicana, introducción, versión rítmica y notas de Rubén Bonifaz Nuño.

Odisea, 2013, México, UNAM, Bibliotheca Scriptorum Graecorum et Romanorum Mexicana, prólogo, versión rítmica e índice de nombres propios de Pedro C. Tapia Zúñiga, estudio introductorio de Albrecht Dihle.

KolB, Frank, Tatort "Troia”. Geschichte, Mythen, Politik, 2010, PaderbornMünchen-Zürich, Ferdinand Schöningh Verlag.

LATACZ, Joachim, Troia und Homer (der Weg zur Lösung eines alten Rätsels), 2004 (2. Auflage), München, Piper Verlag.

Meyer, Erns, "Troia”, en Pauly's Realencyclopädie, Suppl. XIV, 1974, pp. 809-817.

MORRIS, Ian \& Barry Powell (eds.), A New Companion to Homer, 1997, Leiden-New York-Köln, Brill.

PAVEL, Catalin, reseña a Christoph Ulf, Robert Rollinger (eds.), Lag Troia in Kilikien? Der aktuelle Streit um Homers Ilias, 2011, Darmstadt, WBG, Bryn Mawr Classical Review, 2011, <http://bmcr.brynmawr.edu/2011/201110-03.html>. 
Petriconi, Hellmuth, "Das Gilgamesch-Epos als Vorbild der Ilias", en A. S. Crisafulli (ed.), Linguistic and Literary Studies in Honor of Helmut A. Hatzfeld, 1964, Washington, Catholic University of America Press.

SCHADEWALDT, Wolfgang, Iliasstudien, 1938, Leipzig, Hirzel.

SCHROTT, Raoul, Homers Heimat. Der Kampf um Troia und seine realen Hintergründe, 2008, München, Carl Hanser Verlag. "Sieben Prämissen einer neuen Übersetzung der Ilias", en Kofler, Wolfgang, Karlheinz Töchterle und Florian Schaffenrath, PONTES V: Übersetzung als Vermittlerin antiker LiteraturInnsbruck, 2009, Wien-Bozen, Studien Verlag, pp. 405-413.

SCHUBERT, Charlotte, "Homers Heimat. Der Kampf um Troia und seine realen Hintergründe”, reseña, Historische Literatur, 6/2, 2008, <http://edoc.huberlin.de/e_histlit/2008-2/HTML/AG_2008-2.php\#10919> (19 septiembre 2014).

STEINER, George, Lenguaje y Silencio (ensayos sobre la literatura, el lenguaje y lo inhumano), 1982, Barcelona, Gedisa, traducción de Miguel Ultorio.

STRABO, The geography of, 1926-1970, Cambridge, The Loeb Classical Library, vol. VI, books XIII-XIV, with an English translation by Horace Leonard Jones. SzLEZÁK, Thomas A., Homer, oder Die Geburt der abendländischen Dichtung, 2012, München, Verlag C. H. Beck.

UlF, Christoph, "Was ist und was will 'Heldenepik'?", en Ch. Ulf (ed.), Der neue Streit um Troia. Eine Bilanz, 2003, München, Verlag C. H. Beck. Robert Rollinger (eds.), Lag Troia in Kilikien? Der aktuelle Streit um Homers Ilias, 2011, Darmstadt, WBG (Wissenschaftliche Buchgesellschaft). VERMEER, Hans J., Troia und Homer (der Weg zur Lösung eines alten Rätsels), reseña, Nova Tellus, 23.2, 2005, pp. 233-246.

WeST, Martin Litchfield, "The Date of the Iliad", Museum Helveticum, 52, 1995, pp. 203-219. 
CITAM Derechos Reservados.

La reproducción total o parcial de este artículo se podrá hacer si el ITAM otorga la autorización previamente por escrito. 


\title{
DIÁLOGO DE POETAS
}

\begin{abstract}
Antes que la industriosidad, Antonio Deltoro (Ciudad de México, 1947) ha privilegiado la laboriosidad. Si hay acción, ésta apenas logra distinguirse del reposo: la poesía como una prolongada sedimentación de lo real. La textura resinosa o ambarina de la obra de Deltoro permite a los seres, objetos y sensaciones apresados en ella —o, mejor dicho, repantigados_- desafiar la liquidez de nuestra época. A la luz meridiana, pero estroboscópica, de sus poemas, todo cuanto acontece es fruto de una sosegada contemplación. Podríamos imaginar a Deltoro recostado a la sombra del mundo, aguardando el instante en que las imágenes se depositan silenciosa y blandamente en su regazo.

Cercanos en su tono celebratorio y en su ligereza formal a las Odas elementales de Pablo Neruda, los siguientes inéditos constituyen estudios domésticos de campo. Las cosas, en tanto objetos de estudio y de canto, se revelan como el vaso "transparente, / cóncavo y limpio, / hospitalario y cilíndrico" de que habla nuestro autor: sus entrañas son su superficie. El resultado está, literalmente, a la vista. Ni hipótesis de trabajo ni tesis científicas, sino una gozosa pero aguda demora en la inducción: poner sobre la mesa de vidrio del poema el principio particular de lo observado.
\end{abstract}

Hernán Bravo Varela. 


\title{
Poemas
}

\author{
Antonio Deltoro
}

\section{A Un Vaso}

Querido vaso

que me esperas

predestinado

a la cerveza

$y$ al agua:

cercano

al manantial, vigoroso, honesto como el martillo, tan a la mano de la mano, tan adaptado a la palma y los dedos. 
No te empolvarás en la costumbre; no dejará de ser un privilegio

llevarte, lejos del charco a los labios, libre de tierra,

querido vaso que me esperas, transparente, cóncavo y limpio, hospitalario y cilíndrico, en la confianza de la mesa. 


\section{LUCAS}

¿Qué hermoso gato anda suelto?

¿El viejo gato

que envuelve

y que sonríe?

¿El gato

con modales de zorra?

¿El gato erizo

en su casa de púas, que sucede a la noche de farra?

¿El diurno de sueño clandestino, el gato satisfecho de su noche? 
¿El gato vespertino, en la hora que el gato se despierta?

¿El gato en su sueño, equidistante del erizo y la zorra?

¿La zorra, soñando sus hazañas?, ¿el erizo, durmiéndolas?

¿El gato cazador del pájaro enorme, azul y confiado que murió en el balcón, sin saber que detrás del alpiste había gato encerrado? 


\section{LA BARRANCA Y LA ALBERCA}

Eran vecinas todo el día y lo más inquietante, la noche entera.

Separadas, por la tierra de nadie, que esconde a la barranca y que engaña a sus presas, eran aliadas clandestinas del peligro, siempre sucio y salvaje.

La alberca, prometedora, la barranca, cumplidora y paciente, ahora se juntan y tejen, sin sueños, mis pesadillas:

la barranca, sin la alberca, se presenta de noche, segura de la ley de la caída: 


\author{
ella no distingue \\ de basura y de gente: \\ todo desaparece \\ pudriéndose, \\ entre sus fauces \\ que no digieren, \\ ni entierran... \\ tantos años de tentar \\ a las barrancas, \\ para desbarrancarse \\ y que no vengan \\ los zopilotes, \\ todavía, \\ a llevarme difunto, \\ en su vientre, \\ que se eleva \\ y defeca.
}


CITAM Derechos Reservados.

La reproducción total o parcial de este artículo se podrá hacer si el ITAM otorga la autorización previamente por escrito. 


\section{BAJO LA TORMENTA}

Jonathan García Palma*

\section{Josué salió de la habitación y bajó las} escaleras despacio. Se detuvo al llegar al último escalón. La mirada fija en el suelo y la mente aún ocupada en aquello que dejaba atrás. Pensó en volver. Fue in instante. Las frías manos le temblaban un poco. Le era imposible pensar más. Reanudó la marcha después de un último suspiro. Segundos después ya se encontraba en la calle.

Elisa continuaba sentada en su cama. Las palabras de Josué aún giraban en su mente. Intentaba descifrarlas, quería comprender lo sucedido, pero el orgullo le impedía ver más allá de su propia sombra. Se sumergía, cada vez más, en un mar de ideas y sensaciones; en lugar de entender se confundía con mayor fuerza. Rechazaba las frases que le perseguían, negaba con la cabeza y golpeaba la cama con ambas manos. Comenzó a llorar. Se tiró al suelo y continuó golpeando. Lo culpaba a él. Lo maldecía. Lo odiaba.

Él cruzaba la calle cuando recordó lo que escuchara mucho tiempo atrás: "el amor puede convertirse en odio". A su mente llegaron otros pensamientos y unas cuantas imágenes. Ahí estaba Elisa, en su memoria, frente a él. Lo dicho por ella, minutos antes, le perseguía también. Nuevamente se detuvo y quiso mirar hacia atrás. No fue capaz. La razón le obligaba a continuar hacia adelante. Estaba confundido: dos extrañas fuerzas luchaban en su interior y la razón se batía a duelo con una emoción que él desconocía y a la cual le era imposible nombrar.

* Pedagogía (UNAM); cuentista. 
“¡Tú tampoco sabes! ¡Tú tampoco!”, gritaba ella. Las lágrimas rodaron por sus mejillas y llegaron a sus manos, a sus piernas, al suelo. Sentía un gran dolor. “¡Te odio! ¡Te odio!”, exclamaba en medio del 1lanto. “¡Te odio tanto!”, continuaba gritando. Él pudo escucharle a pesar de la distancia. Reconocía que le había herido profundamente; pero pensaba que no estaba lastimado su corazón, sino su orgullo, su soberbia, su egoísmo. "Yo también te odio", susurró él mientras giraba el cuerpo y miraba la ventana de la habitación de Elisa. La luz aún era perceptible. Volvió a caminar, aunque deseaba correr.

Después de unos minutos de llanto y recuerdos, de gritos y golpes al suelo, de pensar y sentir, Elisa comprendió que había algo cierto en las palabras de Josué. Le detestaba y, en aquel instante, hubiera deseado verlo suplicándole, implorando por su perdón. Le había insultado, le había dicho tanto en tan poco tiempo, le había asestado un terrible golpe. Lo destruía. Una frase continuaba en su cabeza y en su corazón: "Tú no sabes amar".

“¡Por supuesto que no sé amar! ¡Claro que no lo sé! ¡Soy egoísta y nunca miro más allá!", exclamaba. "Pero, tú tampoco lo sabes. De lo contrario, nunca me hubieras dicho eso. Tú tampoco me amas, ya lo sé”,

126 añadió, sin gritar, luego de unos cuantos segundos. En ese instante se dejó caer por completo en el suelo y permitió que la ira y todo lo que sentía fluyera libremente. Cerró los ojos y las lágrimas cesaron paulatinamente.

Aparecieron los recuerdos. Regresaron las sensaciones y las imágenes. Se presentaron las palabras y los silencios. Una escena le seguía a otra. Elisa se dejaba mover, se dejaba tocar por la alegría del pasado y por el actual dolor. No opuso resistencia como lo había hecho minutos antes; dejó que la mente lidiara con su corazón. Josué hacía lo mismo bajo la incipiente lluvia que amenazaba con transformarse en tormenta. Él cerró los ojos en medio del camino, se alejó de todo y se dispuso a escuchar su interior. Ambos deseaban encontrar una respuesta.

Un rayo cruzó el cielo y el trueno se escuchó clara y poderosamente al cabo de unos instantes. Después, la oscuridad reinó. Elisa, ya de pie, era incapaz de ver su sombra. Se mantenía inmóvil. Las gotas de lluvia 
golpeaban los cristales de la ventana. La tormenta exterior acompañaba a la que se desarrollaba en su interior.

Afuera, a la distancia, él se encontraba empapado. El viento movía su saco y el cabello violentamente, como deseando cambiarlo de lugar, Pero él se mantenía de pie, en silencio. Sólo podía atender a la tempestad en su interior. La lluvia y los relámpagos no lo inmutaban. De pronto, un par de lágrimas brotaron de sus ojos y alzó la vista al cielo. “i¿Por qué?!”, exclamó. No sabía qué hacer. Estaba confundido, aturdido, conmocionado. Lentamente distinguió algo en su ser: odiaba a Elisa.

"No me hace falta saber más", dijo ella mientras se levantaba del suelo. “Tú tienes razón, tú tienes razón”, expresó al bajar por las escaleras en medio de la penumbra.

"Yo tampoco... Nunca lo he sabido en realidad", dijo él mientras emprendía el camino de regreso.

Segundos después, Elisa ya se encontraba bajo la lluvia. Se preguntaba a dónde ir; cerró los ojos y escuchó el sonido de la tormenta. Cuando alzó la mirada, simplemente corrió hacia la izquierda. Avanzó unos cuantos metros y se topó, frente a frente, con Josué.

"Elisa", dijo él. "Josué", respondió ella.

Se hizo un silencio. La tormenta, testigo de todo, hizo una pausa para permitir que la escena continuara. Era una calma claramente fugaz. La iluminación volvió, aunque débilmente. Un extraño brillo acompañó a la mujer por un instante. Ambos quisieron pronunciar alguna palabra, pero se contuvieron. Las palabras los habían herido antes, así que callaron.

Cada uno respondía sus propias preguntas. Se miraban fijamente. Respiraban agitados. Y así, desde el interior, lograron percibir lo que antes no habían logrado observar. Se abrazaron fuertemente, como si la vida se les fuera en ello.

No necesitaban saber más.

"Es verdad, amar también es morir", dijo él con la voz entrecortada, mientras caía al suelo. La sangre fluía sin cesar por su espalda. Trató de asirse del vestido de Elisa, pero fue imposible. Ella, de pie frente a él, aún sostenía el cuchillo. Le había herido de muerte. 
Un rayo partió el cielo por la mitad. La oscuridad reinó nuevamente y el silencio fue opacado por la tormenta, que reiniciaba con renovada furia.

Josué miró al cielo, susurró el nombre de ella y después cerró los ojos.

La soberbia y la cólera de Elisa se regocijaron, mientras su cuerpo emprendía el camino de regreso a casa, a través de las sombras, en medio de su penumbra interior. 


\section{LA ENCRUCIJADA DE LA DOBLE MEMORIA EN PLOTINO Y EN EL PLATONISMO TARDOANTIGUO José Molina Ayala*}

DOUBLE MEMORY CROSSROADS IN PlotinUS AND LATE PlatonISM

RESUMEN: El tema de la memoria es infinito. En este texto el autor se ocupa de la memoria, facultad del alma que recuerda, en el platonismo tardoantiguo, específicamente en Plotino ("Sobre los problemas del alma"). El tema no es sencillo, pero este acercamiento permite ordenar las conpeciones antiguas de la memoria, así como situarlas en su contexto temporal en la tradición de la Antigüedad.

Palabras Clave: memoria, Plotino, Jámblico, platonismo tardío, alma.
ABSTRACT: The topic of memory is infinite. The author reflects on memory, that faculty of the soul that remembers from the perspective of late Platonism, particularly that of Plotinus ("Problems with the soul"). This topic is challenging but by doing so we can classify the old notions of memory and give them their appropriate place in the Antiquity tradition.

KEYwORDS: memory, Plotinus, Iamblichus, Platonism, late, soul.
RECEPCIÓN: 11 de diciembre de 2014.

ACEPTACIÓN: 14 de enero de 2015.
* Centro de Estudios Clásicos, Instituto de Investigaciones Filológicas, UNAM. 


\author{
LA ENCRUCIJADA \\ DE LA DOBLE MEMORIA EN \\ PLOTINO Y EN EL \\ PLATONISMO TARDOANTIGUO
}

$\mathrm{E}_{1}$ en esta nota sólo me ocuparé del platonismo de la Antigüedad tardía, más específicamente de Plotino, sobre quien debo hacer algunas consideraciones previas que me parecen pertinentes.

Plotino nació y vivió en el siglo tercero después de Cristo; de modo que ya existen entre él y Platón más de cinco siglos. Esta diferencia suele soslayarse, porque se compara el pensamiento plotiniano con sus fuentes fundamentales, y ocurre que la búsqueda y crítica de sus fuentes deja a Plotino y demás platónicos de la Antigüedad tardía como meros o malos repetidores de las doctrinas aristotélicas y platónicas, y a nosotros nos deja como quien pela una cebolla, llorando y sin nada. Este enfoque es, digámoslo de una vez, errado; dicho de otra manera, no se puede hacer la valoración de Plotino y de otros de sus contemporáneos usando como criterio único su adhesión o separación con respecto al pensamiento de Platón o de Aristóteles; hay que aprender a juzgarlos en sus propios términos, sin dejar por eso de hacer las precisiones necesarias respecto de sus fuentes. Más allá de soslayar los aportes originales de los platónicos tardoantiguos, se ha llegado incluso a suponer, con perniciosas consecuencias, que alguna de sus interpretaciones es en realidad algo presente en Platón mismo, lo cual es más grave tratándose de un asunto tan importante como la postulación de la existencia de dos 
mundos distintos: éste en que vivimos y otro de las ideas; por eso, Gadamer, ya en 1996, encuentra necesario señalar que "la belleza, la justicia, el bien no son en ningún momento un segundo mundo de esencias. Este último es una ontologización errónea de las intenciones de Platón, originada por el influjo de la tradición posterior". Ese supuesto segundo mundo, continúa Gadamer, "se perfila ya en la crítica de Aristóteles, quien, por su parte, se guiaba por su interés en la física. Es el neoplatonismo -así llamamos hoy a esa tradición- el primero que convierte a Platón en un pensador de la trascendencia". ${ }^{1}$ De modo que, para la recta lectura de lo que de verdad dijo Platón y para la justa valoración de los platónicos tardoantiguos, hay que hacer un deslinde puntual que no traslape o proyecte la doctrina de éstos en aquél ni viceversa.

Plotino ya es, digámoslo así, uno de nosotros, alguien que va al pasado de la Grecia clásica a buscar soluciones para su propio tiempo, y en ese sentido nos debe inspirar porque hemos de decir que él no fracasó en su empresa, sino que con gran originalidad, por estar sustentada sobre la exégesis y el comentario de los textos antiguos, tomando muy en serio y vitalmente su platonismo, supo ser libre y poderoso para exponer su propio

${ }^{1}$ H. G. Gadamer, El inicio de la filosofia occidental, 1999, Barcelona, Paidós (Paidós Studio, 112), p. 66. pensamiento en escritos altamente condensados e intrincados. Para aproximarse a los tratados plotinianos, que son fabulosas y prodigiosas síntesis de los autores antiguos en general y de Platón en particular, no basta desenredar la madeja de las fuentes.

Otro factor que perturba el juicio sobre Plotino es el desconocimiento que suele tenerse de sus contemporáneos; pocas veces se percibe que el debate, más que con Aristóteles o con Platón, es con personajes más cercanos a su tiempo, con Alejandro de Afrodisia o con Porfirio o con los gnósticos o con otros. Afortunadamente, la filología últimamente nos ha puesto en las manos las fuentes de los autores de la Antigüedad tardía, aunque aquí en México todavía nos queda mucho por leer y estudiar.

Así advertidos, diré que el tema de la memoria en Plotino está tratado principalmente en medio de una exposición Sobre los problemas del alma, que ocupa los tratados del tres al cinco de la cuarta Enéada, ${ }^{2}$ se trata de un exposición sobre temas importantes vinculados con la manera en que el alma se relaciona con el cuerpo, de los cuales Plotino se ocupó aguijoneado ya por la presencia de Porfirio, y hay que saber que, como dice Riccardo Chiaradonna, "el tratamiento de Plotino del tema de la memoria es posi-

${ }^{2}$ En otras partes de las Enéadas hay pasajes pertinentes, pero básicamente la doctrina sobre la memoria está en estos tratados. 
blemente la sección más desconcertante y difícil de las Enéadas". ${ }^{3}$

El asunto no es transparente para quien se acerca por primera vez al platonismo tardoantiguo: hay que distinguir entre distintos tipos de alma; entre el Alma, entendida como hipóstasis (la cual se originó a partir del Intelecto, que a su vez se originó a partir del Uno), y el Alma del mundo y el alma individual, que es, ante todo y de acuerdo con los principios ortodoxos del platonismo, una entidad no corpórea. ${ }^{4}$ Por otro lado, como una consideración pertinente pero anterior, Plotino deja claro que, a diferencia del alma, el intelecto no tiene memoria, pues sus objetos le están presentes en todo momento y no la necesita; tampoco necesitan memoria los cuerpos celestes que están animados; de manera que el tema de la memoria es, preponderantemente, un tema antropológico en que se entrecruzan muchos asuntos de diversa índole: ontológica, cosmológica, psicológica, etcétera.

La memoria es una facultad que sólo pertenece al alma individual mientras está en el cuerpo, pues mientras está en el mundo inteligible, como

${ }^{3}$ R. Chiaradonna, "Plotinus on Memory, Recollection and Discursive Thought", en L. Castagnoli y P. Ceccarelli (eds.), Greek Memories: Theories and Practices, Cambridge, Cambridge University Press, en prensa.

${ }^{4}$ Véase el capítulo III, "El alma, el mundo y el hombre en la enseñanza de Plotino", en F. García Bazán, Plotino y la mística de las tres hipóstasis, 2011, Buenos Aires, El Hilo de Ariadna, pp. 237-97. señalamos, no la necesita. Porfirio, por ejemplo, para mostrar la virtud superior de su maestro, en su Vida de Plotino, ${ }^{5}$ describe cómo no le era necesario revisar dónde se había quedado, si había sido interrumpido mientras escribía; sucede como si, por ejemplo, un enamorado le dijera a su amada, "no te recuerdo pues no te olvido"; eso sería una imagen de la vida del alma que vive en el intelecto. El asunto se volverá importante; no hay que olvidar que, según Plotino, el alma humana no desciende del todo cuando entra en el cuerpo, sino que hay un alma o una parte del alma que no desciende y que está permanentemente en contacto con la vida del intelecto, no sujeta a las vicisitudes de la realidad temporal y conociendo las realidades eternas y permanentes.

Plotino comienza con una pregunta importante, ¿qué o quién es lo que recuerda? Y su respuesta es el alma. Podría parecer obvio, pero le es importante separarse de la visión física o mecanicista de la memoria como mero archivo de las impresiones. Tal como Platón estableció en el Teeteto, es el alma la que percibe, la que conoce, y no el ojo ni la mano; también Plotino establece como principio de una facultad, tal como la memoria, no la descripción física de

${ }^{5}$ Porfirio, Vida de Plotino, 8 (Plotin, Ennéades, 1924, Paris, Société d'Édition «Les Belles Lettres», trad. Émile Bréhier). 
un fenómeno, sino un sujeto que ejerce dicha facultad. Esa facultad, la memoria, se confunde con otra, que es la imaginación. De hecho, la imaginación sola ya es cierta memoria, porque puede hacer presente lo que está ausente; el énfasis de la caracterización de la memoria, en contraste con la imaginación, está puesto en que la memoria retiene la imagen; en efecto, Jámblico, en su tratado Acerca del alma, define la memoria como "retención de la imagen" (he mneme katojé ousa phantásmatos), ${ }^{6}$ puesto que se hace énfasis en que el alma, mediante esta facultad, retiene y evita que se pierda la imagen formada por la imaginación. Se sabe ahora que la palabra katojé no formaba parte del vocabulario de los escritos no espurios de Aristóteles: se la encuentra en Porfirio, en Jámblico y en un epítome del tratado Sobre la Memoria de Aristóteles. Se trata, pues, de una reelaboración léxica de lo que Aristóteles llamaba una hexis, una posesión.

Cabe hacer notar que la precisión mediante la cual se caracteriza a la memoria como retención es importante porque, de esta manera, se evita una visión meramente física de la memoria, que pondrá énfasis en la fuerza con que lo sensible se imprime en el

${ }^{6}$ Jámblico, Acerca del alma, 14 (Iamblichus, De Anima, 2002, Leiden, Brill, edición de F. Finamore y John M. Dillon). alma; para explicar esta visión, digamos mecanicista de la memoria, suele recurrirse a una imagen usada por Platón en el Teeteto, que es la de la cera en que se graban las impresiones; la memoria, pues, sería como una inscripción que permanece en la tablilla, dependiendo de la fuerza con que se hizo y de la cualidad de la cera. Pero, ¿cómo se "graban" los recuerdos en la mente? Aristóteles, en el inicio de la Metafisica, sostiene que una experiencia fundamental para el arte y la ciencia se configura por la multitud de recuerdos del mismo asunto $;{ }^{7}$ no es gratuito que, cuando en la escuela queríamos aprender algo de memoria, solíamos repetirlo infinitas veces; allí mismo, Aristóteles señala que los animales que tienen memoria son más inteligentes, pero eso no significa que memoria e inteligencia se confundan; añade que aprenden quienes tienen oído. Es curioso que la memoria suele asociarse con el campo de lo visual, o con los sueños, lo cual ocurre por su vinculación con la imaginación; pero esta asociación de la memoria con el oído para el aprendizaje se precisa más en el tratado aristotélico Sobre la memoria, ${ }^{8}$ que sin duda Plotino tomó

${ }^{7}$ Aristóteles, Metafísica, 980 b 29-981 a 1.

${ }^{8}$ Aristotle on Memory and Recollection, 2007, Leiden/ Boston, Brill, Text, Translation, Interpretation, and Reception in Western Scholasticism by David Bloch. 
en cuenta; ${ }^{9}$ la memoria se asocia, como los sonidos, no con la luz, en cuyo caso la relación sería espacial, sino con el tiempo; es decir, la memoria tiene relación necesaria con el pasado y el tiempo hace que las impresiones de lo sensible se desdibujen, pero la memoria es la facultad que las fija y las retiene.

La palabra mneme, que suele referir el recuerdo no como objeto sino como proceso psicológico, no está como entrada en el Diccionario Etimológico de Chantraine, ${ }^{10}$ pero sí está mimnesko, el verbo recordar, cuyo infijo-sk-expresa la realización de un proceso repetido; se relaciona, curiosamente no con meno, que significa "permanecer", "mantenerse firme", "estar", "quedarse", sino con memona, con menos y con mainomai. Es un poco sorprendente, o al menos así me lo parece: memona es un perfecto con valor de presente, que,

${ }^{9}$ Sobre la relación entre Aristóteles y Plotino respecto del tema de la memoria puede verse: Henry J. Blumenthal, "Plotinus' Adaptation of Aristotle's Psychology, Sensation, Imagination and Memory", en R. Baine Harris (ed.), The Significance of Neoplatonism, 1976, Norfolk (VI), International Society for Neoplatonic Studies, Old Dominion University. Véase también Angela Longo, "Memoria inattiva e memoria attiva in Plotino ("Enneadi" I 2, 4): un confronto con Aristotele ("De Anima" II 5 e III 4)", en Testis Fidelis. Studi di filosofia e scienze umane in onore di Umberto Galeazzi, 2012, Napoli, Orthotes Editrice, a cura di Domenico Bosco, Francesco Paolo Ciglia, Luigi Gentile, Loreta Risio, pp. 425-41.

${ }^{10}$ Pierre Chantraine, Dictionnaire étymologique de la langue grecque: Histoire des mots, 1980, Paris, Klincksieck. según el Diccionario Liddell-Scott, ${ }^{11}$ tiene como cognados precisamente a menos y a mainomai, y significa: "desear ardientemente", "estar ansioso de", "aspirar a", "buscar", "tratar de"; "proponerse", "resolverse o determinarse a"; "lanzarse apresurada o violentamente". En este sentido, el arte de la memoria aparece en Plotino como el arte de la atención, y el arte de la atención es el arte del interés. Uno recordaría mejor aquello de lo que uno está ansioso, aquello a lo que uno se lanza con violencia, esto es, a lo que uno está intencionalmente dirigido, digamos, en términos de Husserl.

Por otra parte, la siguiente palabra relacionada con mimnesko, menos, es muy interesante. Menos significa "fuerza", "vigor", "ímpetu”, "poder", "fuerza vital", "vida", "alma", "sangre", "furia", "rabia", "cólera", "intención", "propósito" "temple", "talante", "temperamento". Significativamente, aparece a veces en Homero, en endíadis junto con thymós, que es también "el ánimo", "el furor", "la cólera". Es de notar que Plotino se refiere a la memoria no sólo como una facultad, una dynamis, sino también con isjys, como "fuerza" del alma que retiene la imagen; esa retención es una actividad del alma y no un suceso en que el alma permanezca pasiva.

${ }^{11}$ Henry George Liddell and Robert Scott, $A$ Greek-English Lexicon, 1968, Oxford, Oxford Clarendon Press, 9a. ed., s. v. mémona. 
En la tradición platónica del Fedro, la palabra con la que anamimneskomai tiene mayores resonancias es mainomai, "poner furioso o rabioso", "rabiar", "estar loco", "alocado", "transportado", "fuera de sí", "estar poseído", "estar cegado", "mostrarse simple e indiscreto", "moverse o lanzarse con furia"; el verbo tiene que ver con manía. Platón en el diálogo citado se refiere a cuatro manías por las cuales el alma recupera las alas que perdió al encarnarse en un cuerpo: ${ }^{12}$ la manía del enamoramiento, que fácilmente puede uno relacionar con el Banquete, la vía ascendente de la belleza por la cual el alma enamorada recuerda lo percibido antes de encarnarse; como en su Piedra de Sol recuerda platónicamente Octavio Paz, que cuando dos se besan "brotan las alas en las espaldas del esclavo", el alma recuerda que antes estaba alada y el amor le ayudaría a recuperar sus alas. Platón también le reserva un lugar a la manía propia de la poesía, de modo que también el poeta recuerda su origen celeste. Es el poeta quien, con sus obras, trae al mundo una prueba de la existencia de un ámbito superior al meramente sensible; Hesíodo, por ejemplo, en su Teogonía da a conocer el canto que recitan las deidades cuando se reúnen; el poeta tuvo acceso a lo que pasa en la dimensión celeste. Como decía Hölderlin, "todo lo que permanece lo fundan los poetas", y lo que permanece, porque pertenece al ámbito celeste de lo eterno, es lo que se recuerda gracias a las facultades poéticas.

Otra manía, es decir, otra forma del recuerdo, otra manera en que el alma percibe que los datos de lo sensible no son lo único o lo definitivo, es la del entusiasmo religioso, relevante en el contexto del platonismo tardío, en el caso de la confrontación entre Plotino y Jámblico. Este último había señalado la teúrgia como el medio óptimo y más elevado mediante el cual las almas se unen subsecuentemente a los dioses, al Intelecto y finalmente al Uno. Pero esta unión no podía ser conseguida por los medios meramente intelectuales del ser humano, sino que era concedida por los dioses en los ritos teúrgicos; por el contrario, Plotino y Porfirio decían que son los medios intelectuales propios de la filosofía quienes podían conseguir esta unión; de hecho, la filosofía es precisamente otra manía de las señaladas por Platón en el Fedro.

Plotino, considerando la esencia pura del alma, anula una facultad como la memoria; según Jámblico ${ }^{13}$ la anula por considerarla una facultad irracional que se adhiere al alma sólo cuando está en el cuerpo, pues Plotino considera que sólo el razonamiento puro, sin mezcla de lo sensible, tiende hacia la esencia pura del alma, como si dicho razonamiento, ya libre de las 
perturbaciones de lo corporal, tuviera una facultad connatural respecto a la idea misma de su sustancia. Pero, también según Jámblico, Platón considera a la memoria como algo propio de las almas mismas y de los seres vivos, distinguiéndola de acuerdo con cada vida, o bien, de acuerdo con la vida del alma en sí misma, o bien, con la vida del alma en el ser vivo, en el cuerpo animado. Según Jámblico, para Porfirio y Plotino las almas proyectan sus facultades sobre el universo, se originan o se desarrollan por los requerimientos de la vida contaminada con lo sensible; pero una vez que cesa su vida material, sus facultades también se pierden o se retraen hacia el alma; sin embargo, Jámblico cree que es verosímil, dado que cree que el alma se encarna del todo, que sus facultades, entre ellas la memoria, están y permanecen en el universo y que quizá no se pierden. La memoria es una facultad que está en el alma, pero no es symplerotiké de ella, esto es, ni es capaz de completarla ni forma parte esencial de ella.

Ahora bien, cabe recordar que en el drama que en el pensamiento plotiniano vive el alma como hipóstasis, es decir, como entidad autónoma, generada por el intelecto, ésta se atrevió, tuvo la osadía (tolmé) ${ }^{14}$ de arrojarse hacia la materia; casi como adolescente rebelde que busca individuarse, se olvida de quién es su

\footnotetext{
${ }^{14}$ Plotino, Enéada V, 1 (30), 1
}

padre, del intelecto, y se olvida de sí misma. Este atrevimiento es el que ha hecho que el alma se arroje hacia lo sensible, y arrojándose a lo sensible se entrega entera a lo divisible, se une a la materia y la organiza. Y como el mismo Plotino hace la precisión, los principios de todo, el Uno, el Intelecto y el Alma arquetípica, también se dan proporcionalmente en el ser humano, de modo que también el alma humana ha vivido análogamente ese drama del olvido de sí e igualmente se ha olvidado de sus principios. El trabajo filosófico estribará prácticamente en conseguir que el alma se acuerde de quién es ella, en su más profundo ser, una sustancia incorpórea, y recuerde los vínculos esenciales que la unen con el intelecto, de quien, según Plotino, no llega a separarse nunca del todo. Esta doctrina del alma no descendida del todo es lo que diferencia a Plotino también de los otros filósofos platónicos de la Antigüedad tardía, y de manera importante lo diferencia de Jámblico quien, por un mayor aristotelismo, concibe que el alma desciende por completo a la materia; enseña también que no sin concurso de la materia y, además, con ayuda de los dioses, el alma emprenderá su regreso al ámbito inteligible.

Pero Plotino especifica que la memoria es doble, o bien, que hay dos memorias, dependiendo del objeto hacia el que esta facultad tiende, 
y en esto, aun bajo la perspectiva de Jámblico, es platónico ortodoxo. La memoria puede tender hacia lo sensible; recordamos que es una facultad del alma mientras el alma está en el cuerpo; esta memoria hace presente al alma lo que en determinado momento está ausente, en este caso lo sensible, y en el acto de recordar la facultad simultáneamente se vuelve consciente de sí misma, recuerda y se da cuenta de que recuerda; pero hay otra memoria que está en estado inconsciente, que persigue las realidades inteligibles y que más que una facultad debe concebirse como una disposición (hexis), dado que ésta considera objetos que el alma retiene en sí misma (aquí vuelve el término catojé); en este caso lo ausente, a lo cual esta memoria puede o no llegar a hacer presente, son realidades inteligibles, los objetos de conocimiento que se hallan en el Intelecto; cabe mencionar también que, para Plotino, a diferencia de lo que cree Aristóteles, el alma puede pensar sin imágenes, y en caso de presentarse la memoria superior, la que de manera consciente ya no se dirige a lo sensible, en ella los recuerdos no son imágenes de lo material, sino reflejos de los inteligibles, de las realidades eternas. Mientras que a la memoria sensible la llama mneme, Plotino parece reservar a la memoria superior el nombre de anamnesis. Por otra parte, cuando el alma está en esta memoria superior, en vida o habiendo dejado al cuerpo, el recuerdo de los objetos de la memoria inferior se vuelve superfluo, como si sus objetos cayeran en el olvido, como si sólo quedaran en estado latente.

Consecuentemente, como hay dos memorias, habrá dos olvidos, ${ }^{15}$ y un constante recuerdo de lo sensible provocará el olvido de lo inteligible, y viceversa, la memoria de lo inteligible dejará en la sombra del olvido a lo sensible, como en una especie de quiasmo. Lo interesante es que también para Plotino lo sensible puede ser ambiguo porque, o nos ata a lo sensible, o, de acuerdo con el trabajo del alma, también lo sensible puede ser punto de arranque para el ascenso del alma hacia lo inteligible; el filósofo, por su actividad intelectual, sabrá descubrir los vestigios de lo inteligible en lo sensible y, aunque parezca que hace lo mismo que las demás personas, su vida será más plena porque tendrá cada vez más memoria de sus principios y de sí mismo. ${ }^{16}$

${ }^{15}$ D. P. Taormina, "Plotino. El alma y sus dos olvidos", Revista Latinoamericana de FilosofíaAnejo 2010, pp. 353-84.

${ }^{16}$ Para la elaboración de estas líneas me basé fundamentalmente en los siguientes trabajos, que generosamente Daniela Patrizia Taormina puso en mis manos; son más amplios y detallados, más precisos y profundos, son esenciales y un excelente comienzo para tratar el tema de la memoria en Plotino: D. P. Taormina, "Dalla potenzialità all'attualità. Un'introduzione al problema della memoria in Plotino", en Thomas Bénatouil, Franco Trabattoni, Gerd Van Riel (eds.), Plato, Aristotle or both? 
Dialogues between Platonism and Aristotelism in Antiquity, 2010, Hildesheim, Olms, pp. 139-59; id., "Plotino. El alma y sus dos olvidos", Revista Latinoamericana de Filosofía-Anejo 2010, pp. 353-84. Riccardo Chiaradonna, "Plotinus on Memory, Recollection and Discursive Thought", en L. Castagnoli y P. Ceccarelli (eds.), Greek Memories: Theories and Practices, Cambridge, Cambridge University Press, en prensa. También son muy útiles y luminosos, aunque de modo colateral a lo aquí expuesto: D. P. Taormina, "Coloro che guardano e provano un turbamento. Memoria degli intelligibili e percorso anagogico secondo Plotino, trattato 33
[II 9] 16", M. Marsola, L. Ferroni (eds.), Estratégias anti-gnósticas nos escritos de Plotino, San Paolo, Rosari \& Paulus (en prensa), prefazione J.-M. Narbonne; R. Chiaradonna, "Plotinus' Account of Cognitive Powers of the Soul: Sense Perception and Discursive Thought", en Topoi 31 (2), pp. 191201; Angela Longo, "Memoria inattiva e memoria attiva in Plotino ("Enneadi" I 2, 4): un confronto con Aristotele ("De Anima" II 5 e III 4)", en Testis Fidelis. Studi di filosofia e scienze umane in onore di Umberto Galeazzi, 2012, Napoli, Orthotes Editrice, a cura di Domenico Bosco, Francesco Paolo Ciglia, Luigi Gentile, Loreta Risio, pp. 425-41. 


\section{¿ES LA DEMOCRACIA MODERNA RESULTADO DE LAS TEORÍAS POLÍTICAS OCCIDENTALES? \\ El caso de la liga iroquesa y la constitución estadounidense \\ María Julia Sierra*}

RESUMEN: Este texto destaca la influencia y participación de la Liga iroquesa -conjunto de grupos amerindios- en la unificación de las colonias inglesas de América y en la creación del sistema federalista de Estados Unidos. Mediante la labor de algunos intelectuales como Franklin y Morgan, la influencia iroquesa se puede constatar en Marx y Engels y en el siglo XX con los movimientos de reivindicación cultural.

Palabras Clave: Liga iroquesa, Costitución estadounidense, Benjamín Franklin, Lewis Morgan, democracia.

\section{IS OUR MODERN DEMOCRACY A PRODUCT OF WESTERN POLITICAL THEORY? \\ THE CASE OF THE IROQUOIS NATION AND THE AMERICAN CONSTITUTION}

ABSTRACT: In this article, we will highlight the influence and the role of the Iroquois nation -a group of North American Indians- in the unification of the English colonies of America and in the creation of the American federal system. Due to the work of intellectuals like Franklin and Morgan, the Iroquois influence can be seen in Marx and Engels and in the twentieth century movements of cultural revindication.

KEYWORDS: Iroquois Nation, American Constitution, Benjamin Franklin, Lewis Morgan, democracy.

* Departamento Académico de Estudios Generales, ITAM. 


\section{¿ES LA DEMOCRACIA MODERNA RESULTADO DE LAS TEORÍAS POLÍTICAS OCCIDENTALES? \\ El caso de la liga iroquesa y la constitución estadounidense}

\section{Introducción}

\section{Las relaciones interculturales desde el siglo $X V I$}

Todos hemos oído hablar de los intercambios entre los europeos y los pueblos indígenas de América. Siempre se enumeran plantas, animales, metales y productos que pasaron de uno a otro continente; ${ }^{1}$ con todo esto se transformó la economía del sistema

${ }^{1}$ Como ejemplos de productos americanos que llegaron a Europa se pueden citar: metales y piedras preciosas como la plata y las esmeraldas; jitomate, aguacate, cacao, chocolate, guajolotes o pavos, grana, cochinilla, papa, y muchos otros. Entre los productos que los europeos trajeron al nuevo continente podemos mencionar: ovejas, vacas, cabras, caballos, trigo, cebada, centeno, vid, aceitunas, algodón, paños de lana, así como diversas tecnologías agrícolas, mineras y textiles. mundial. Se cambiaron los hábitos alimenticios y de consumo; los paisajes se transformaron con los nuevos cultivos y las nuevas actividades económicas, en uno y otro lado del Atlántico. No todos los intercambios fueron positivos: los españoles también trajeron al nuevo continente muchos gérmenes que diezmaron a las poblaciones aborígenes, ${ }^{2}$ porque éstas no tenían los anticuerpos requeridos para sobrevivir, lo que facilitó las conquistas militares y los procesos de colonización. Las corrientes

${ }^{2}$ Cfr. Sherburne F. Cook y Woodrow Borah, Ensayos sobre historia de la población: México y el Caribe, 1968, México, Siglo XXI, traducción de Clementina Zamora. En esta investigación se habla de un verdadero desastre demográfico, pues la población mesoamericana sufrió un descenso de casi las tres cuartas partes del total en sólo una generación. 
migratorias se ampliaron y modificaron, produciendo nuevos patrones de poblamiento y diversas formas de mestizaje, que cambiaron la distribución de la población alrededor del mundo.

Se sabe que el proceso de "conquista cultural" no fue sencillo, que hubo resistencias y enfrentamientos violentos. Se crearon nuevas realidades sincréticas que tienen expresiones muy claras en el arte, que tuvo uno de sus clímax en la cultura barroca de América Latina (siglos XVII y XVIII). El discurso de La Angostura, pronunciado el 15 de febrero de 1819 por Simón Bolívar, muestra claramente la conciencia de esta nueva identidad, producto de lo que llamaríamos "mestizaje cultural", cuando afirmó: "No somos europeos, no somos indios, sino una especie media entre los aborígenes y los españoles [...]. Tengamos presente que por nuestras instituciones y por nuestro carácter no somos una emanación de Europa". ${ }^{3}$

Se reconoce que los occidentales trajeron nuevas tecnologías agrícolas, arquitectónicas y militares, así como muchas instituciones; asimismo impusieron sus lenguas y visiones del mundo. Sin embargo, tal pareciera que nunca se consideró la

${ }^{3}$ http://www.columbia.edu/cu/spanish/courses/spanish3350/02independencia/pdf/angostura.pdf, consultada el 12 marzo 2014. influencia de las ideas o sistemas políticos y sociales de los indios en las instituciones de Occidente hasta finales del siglo XX. Paradójicamente, aunque algunos ilustrados consideraron a los indios de América como salvajes, también elogiaron algunas de sus instituciones y costumbres, al punto de inspirarse en ellas, tal como se verá más adelante.

\section{La cuestión antropológica}

Los descubrimientos y conquistas de los siglos XV y XVI revolucionaron las formas de vivir, producir, organizarse, pensar y sentir. Desde el punto de vista antropológico, el aspecto más significativo fue la comprensión de la diversidad humana y la naturaleza de los "indios" que el descubrimiento de América hizo patente. La pregunta no sólo era teórica; se trataba de establecer las leyes que regularan los derechos y obligaciones de cada uno de los grupos socioculturales involucrados en la construcción del nuevo mundo. ${ }^{4}$

${ }^{4}$ Independientemente de algunas posturas que llegaron a considerar que los indios eran casi bestias o esclavos, la mayoría de las autoridades religiosas y el mismo emperador Carlos V los entendieron tan humanos que podían ser evangelizados. Además, como dice Paulo III, en la Bula Sublimis Deus: "A pesar de todo lo que pudo haber sido, o que se pudo decir en contrario, los 'indios' dichos, y 'todas las demás personas' que más tarde pueden ser descubiertas. de ninguna manera deben ser privadas de su libertad o despojadas de bienes, estén 
La constatación de la gran diversidad humana llegó al centro de la reflexión de la Antropología como ciencia, es decir, de las relaciones entre "nosotros" (los que pertenecen a mi cultura y sociedad) y los "otros" (los extraños que no son parte de mi grupo). Sin embargo, mi identidad personal se construye con referencia a ellos. Esto es lo que algunos filósofos como Paul Ricoeur ${ }^{5}$ llaman "el problema de la otredad y la mismidad" y, en última instancia el de la unidad humana. El debate ha continuado a lo largo de los años y ha revestido características diferentes, según los lugares y los valores de los participantes. Los protagonistas principales fueron occidentales hasta la segunda mitad del siglo XX, en que también algunos de los "otros" exigieron ser oídos.

dentro o fuera de nuestra fe, y que pueden y deben, libremente y legítimamente, disfrutar de la libertad y la posesión de sus bienes; tampoco deben ser de ninguna manera esclavizadas, y si ocurre en contrario, entonces eso será nulo y no tendrá efecto". Véase, entre muchos otros: a) Leyes de Burgos, 1512; b) Los Justos Títulos, de fray Francisco de Vitoria en De indis, 1532; c) Bula Sublimis Deus, Paulo III, 1537; d) Junta de Valladolid y la Polémica entre fray Bartolomé de las Casas y Ginés de Sepúlveda, 1550-1551.

${ }^{5} \mathrm{Cfr}$. Paul Ricoeur, El sí mismo como otro, 1995, México, siglo XXI, .

\section{El debate ilustrado}

\section{Natura y cultura}

La reflexión sobre la posibilidad de la unidad humana a pesar de las diferencias llegó al ámbito de la biología. Hubo quienes sostuvieron que había grados de humanidad, de manera que los indios eran inferiores biológicamente; así, se desarrollaron muchas de las corrientes racistas que sobreviven hasta nuestros días. Otras escuelas afirmaban que las causas de la diversidad estaban en el medio ambiente que determinaba el comportamiento humano. Algunos, en cambio, negaron las tesis racistas o deterministas y plantearon la importancia de la cultura en la historia humana.

Los ilustrados franceses como Voltaire y Rosseau, en la primera mitad del siglo XVIII, sostuvieron que el descubrimiento de América fue uno de los grandes acontecimientos de la historia, porque este hecho señala el momento en que la mitad de la humanidad se encontró con la otra, a la que ignoraba. ${ }^{6}$ Así, desde los inicios de la Ilustración, la percepción que tuvieron estos pensado-

${ }^{6}$ "C' $\mathrm{C}$ 'est ici le plus grand événement sans doute de notre globe, dont une moitié avait toujours été ignorée de l'autre. Tout ce qui a paru grand jusqu'ici semble disparaître devant cette espèce de création nouvelle", Voltaire, Essai sur les moeurs, 1972, Paris, PUF, p. 387. 
res frente a la diversidad humana se caracterizó por sus matices igualitarios. En 1875, Jean Jacques Rousseau, en su Discurso sobre el origen de la desigualdad entre los hombres 7 afirmó que la humanidad en sus orígenes era fundamentalmente buena; veía al salvaje en su estado primigenio como incorrupto, lleno de bondad y felicidad porque no había sufrido todavía las terribles desigualdades que existían en la sociedad civilizada.

Posteriormente las cosas cambiaron, porque medio siglo más tarde se llevó a cabo un debate importante que involucró a tres famosos ilustrados. Francisco Xavier Clavijero, uno de los jesuitas criollos novohispanos expulsados de su patria por el decreto de Carlos III de1767, publicó en Bolonia, en italiano, su obra más famosa, Historia antigua de México (1780): ${ }^{8}$ fue traducida a todos los idiomas europeos $\mathrm{y}$, al año siguiente, la completó con nueve disertaciones. El propósito de ambos escritos, tal y como lo afirmó en sus prólogos, fue "restituir a su auténtico esplendor la verdad sobre el México Antiguo,

${ }^{7}$ Cfr., Juan Jacobo Rosseau, Discurso sobre el origen de la desigualdad entre los hombres, http://moreliain.com/secciones/CULTYTRAD/ libros/Juan\%20J.\%20Rousseau\%20-\%20Discurso $\% 20$ sobre $\% 201 \mathrm{a} \% 20$ desigualdad.pdf, p. 48 , consultada el 2 de abril de 2014.

${ }^{8}$ Francisco Javier Clavijero, Historia Antigua de México, 1980, México, Porrúa, Sepan Cuántos, 29, prólogo Mariano Cuevas. verdad ofuscada por una turba increíble de escritores modernos". ${ }^{9}$ Entre los escritores a los que se dirigen sus refutaciones estaban: el naturalista francés Georges Louis Leclerc, conde de Buffon, quien fue uno de los precursores de la biología científica; el antropólogo holandés, Cornelius de Pauw; y el historiador escocés, William Robertson. Estos autores sostenían que los americanos antes de la Conquista eran salvajes, primitivos, incultos, faltos de intelecto, inferiores a los hombres del viejo continente. Los europeos que entraban en contacto con ese nuevo ambiente también se iban degenerando. ${ }^{10}$ Clavijero, como buen ilustrado, también buscaba "hacer prevalecer la razón por encima de los prejuicios" y más adelante critica:

Pauw escribe de los americanos desde su gabinete en Berlín, sin salir de él dice saber las cosas de América [...] No es la realidad occidental la que tienen estos ilustrados como norma suprema sino que es la razón de la superioridad europea la que sobrepasa todas las deter-

${ }^{9}$ Ibid., p. 9.

${ }^{10}$ Para lo cual daban como argumentos las descripciones de Fray Bartolomé de las Casas sobre la conquista de las Antillas. Cfr. la Brevísima relación de la destrucción de las Indias, http://aix1.uottawa. ca/ jmruano/relacion.pdf, consultada el 12 de marzo de 2014, Los escritos de Fray Bartolomé fueron utilizados como argumento en lo que después se llamó la "leyenda negra sobre los españoles". 
minaciones sociales e históricas en sus argumentos". ${ }^{11}$

En síntesis, las ideas que Clavijero sostiene a lo largo de toda su obra es que los indios de América tienen el mismo origen que los europeos, todos procedemos de Adán, por lo tanto los indios no son inferiores a los occidentales. Son igualmente racionales y la historia de las Indias tiene un pasado clásico, tan importante como los antecedentes grecolatinos de Europa. De manera que el mestizaje siempre proporcionará resultados positivos en la historia humana.

\section{Benjamín Franklin y los iroqueses}

Los iroqueses son un conjunto de grupos amerindios, habitaron alrededor de los Grandes Lagos, al sureste de Canadá, y al noreste de los Estados Unidos. ${ }^{12}$

A sí mismos se llamaban Nadowa o Haudenosaunee, es decir, "los de la casa extensa", donde cada uno tiene su propio fuego. Los franceses los llamaron iroqueses, del vocablo algon-

${ }^{11}$ Clavijero, op. cit, p. 25.

${ }^{12}$ Actualmente, en los Estados Unidos se encuentran grupos iroqueses en Nueva York, Wisconsin y Oklahoma; en la región de los lagos Ontario y Erie, Canadá, también existe una comunidad que migró a Francia en la época de la gran depresión, que vive en los departamentos de Aude y Garde de la región de Languedoc. Cfr. Charles Mann, 1491. Nueva historia de las Américas antes de Colón, 2006, México, Taurus. quino irinakhoiw (unión real). ${ }^{13} \mathrm{La}$ familia lingüística iroquesa cuenta con once idiomas. ${ }^{14}$ Eran pueblos nómadas que se volvieron sedentarios. Su economía era autosuficiente, el sistema era mixto basado en la agricultura (cultivaban diversas hortalizas), la silvicultura, la caza, la pesca y la recolección de ciertos frutos. Establecieron entre ellos el intercambio gratuito de regalos mutuos, ${ }^{15} \mathrm{y}$ comerciaban con otras tribus distintas a las de la Liga iroquesa (pieles y diversos abalorios). La propiedad de la tierra era comunal y el trabajo colectivo, con división social de acuerdo al sexo y a la edad. Cada tribu contaba con enormes extensiones de tierras.

Según la tradición oral haudenosaunee, ${ }^{16}$ alrededor del siglo XII ${ }^{17}$

${ }^{13}$ Los algonquinos son otro grupo de tribus amerindias que fueron aliados de los franceses en las guerras franco-británicas. Habitaron el extenso territorio entre Virginia y las Montañas Rocosas, al norte de la Bahía de Hudson. Actualmente, la mayoría de los algonquinos vive en Quebec, cfr., ibid.

${ }^{14}$ Las once lenguas son: tuscarora, nottoway, hurón, laurentiano, onondaga, conestoga, seneca, cayuga, mohawk, oneida y cherokee. Aunque no se ha podido probar el parentesco del iroqués con otras lenguas americanas, algunos lingüistas como Wallace Chafe dicen que podría estar relacionada con las lenguas siux.

${ }^{15}$ A este tipo de economía Marcel Mauss la llama "economía del don", cfr. M. Mausse, Essai sur le don, 1971, París, PUF.

${ }^{16}$ Según los estudios de Bárbara A. Mann y Jerry Fields de la Universidad de Toledo, en http:// iipdigital.usembassy.gov/st/spanish/publication/2009 /07/20090720115214pii0.9292108.html\#ixzz 2zgDS9A2h, consultada el 30 de marzo, 2014.

${ }^{17}$ De acuerdo con esta fecha, la Confederación iroquesa es el segundo modelo más antiguo de parlamento democrático y representativo. El Althing de 
surgió la confederación iroquesa, formada por el jefe hurón Deganawidah, "el Pacificador", quien consiguió la ayuda de Aiowantha (llamado Hiawatha algunas veces) para propagar su sueño de una confederación para controlar las rivalidades sangrientas entre las tribus. ${ }^{18}$ El esquema sociopolítico de la Confederación permitía combinar la soberanía de cada nación iroquesa con la de un gobierno confederado. Cada unidad soberana mantenía el poder sobre sus asuntos internos, mientras que el gobierno mancomunado regulaba y administraba lo relativo a las materias comunes a todos. El Consejo negociaba la paz, pero no podía declarar la guerra, la cual era decisión de los representantes o líderes de cada nación. ${ }^{19} \mathrm{El}$ jefe de la confederación, el Tododaho convocaba a los cincuenta sachems que representaban a los clanes de las cinco naciones; cada nación delegaba un número distinto de sachems, aunque estas diferencias no eran

Islandia fue el primero, porque se estableció en 930 a. C. Cfr. Jack Weatherford, Indian Givers: How the Indians of the Americas Transformed the World, New York, 1988, Fawcett Columbine, pp. 34-52.

${ }^{18} \mathrm{La}$ Confederación incluía originalmente a los mohawks, oneidas, onondagas, cayugas y senecas. La sexta nación, la de los tuscarora, migró al país iroqués a comienzos del siglo XVIII y fue adoptada por ellos. El sitio en el cual el pacto estableció como centro de la Liga se encuentra bajo la ciudad de Siracusa, Nueva York.

${ }^{19}$ Electos democráticamente. Cfr. Gregorio Doval, Breve historia de los indios norteamericanos, 2009, Madrid, Nowtilus. significativas porque todas las decisiones se tomaban por unanimidad, de acuerdo con la Gran Ley de Paz iroquesa. ${ }^{20}$

Benjamín Franklin, otro ilustrado americano, fue impresor, científico, inventor, político y el único padre fundador de Estados Unidos que firmó los cinco documentos que establecieron la Independencia de su país. ${ }^{21}$ Entre 1736 y 1762, en su imprenta de Filadelfia, publicó los tratados indios ${ }^{22}$ en pequeños folletos que tuvieron gran éxito en las colonias. $^{23}$

${ }^{20}$ Uno de los aspectos sobresalientes de esta ley es que, cuando el Consejo de sachems tenía que tomar una decisión realmente importante, sus miembros tenían que someter el asunto a la decisión de su pueblo, en una suerte de referendum, c $f r$. "The Constitution of the Iroquois Nations: The Great Binding Law", GAYANASHAGOWA, trad. Gerald Murphy, en http://www.indigenouspeople.net/ iroqcon.htm, consultada el 24 abril, 2014.

${ }^{21}$ Estos documentos son: 1) la Declaración de Independencia; 2) el Tratado de Concordia y Comercio con Francia; 3) el Tratado de la Alianza con Francia; 4) el Tratado de Paz con Gran Bretaña; y, 5) la Constitución de los Estados Unidos de América.

${ }^{22}$ Benjamín Franklin, Observaciones sobre los salvajes de Norteamérica, trad. del inglés María de los Ángeles Toda Iglesia, Sevilla, 2004, en http:// www.google.com.mx/url? sa $=\mathrm{t} \& \mathrm{rct}=\mathrm{j} \& \mathrm{q}=\&$ esrc $=\mathrm{s}$ \& source $=$ web\&cd $=2 \&$ ved $=\mathrm{C} 0 \mathrm{QFj} A B \&$ url $=\mathrm{http} \%$ $3 \mathrm{~A} \% 2 \mathrm{~F} \% 2 \mathrm{~F}$ revistas.uca.es\%2Findex.php $\% 2 \mathrm{Fcir}$ $\% 2$ Farticle $\% 2$ Fdownload $\% 2$ F286\%2F268\&ei=iy ZXU6TdJuTg2gWxqYD4DQ\&usg=AFQjCNHr6 j38J71 AyN6wp0ia5gojxprY3A, consultada el 20 de marzo de 2014.

${ }^{23}$ Cfr. Miguel León Portilla, De palabra y obra en el nuevo mundo: encuentros interétnicos, 1992, México, Siglo XXI. 
En la asamblea entre los indios y los británicos de Filadelfia, en 1744, el sachem iroqués Canassatego les dijo a los británicos que era necesario crear una organización que, sin afectar la soberanía de cada una de las trece colonias, permitiera unificar sus voces para tratar con otras naciones. ${ }^{24}$

En 1750, fue nombrado Comisionado de asuntos indios de Pennsylvania y, en 1754, participó en el Congreso de Albany, reunión organizada por la Cámara de Comercio Británica, que buscaba la alianza de los indios en contra de los franceses durante la Guerra de los Siete Años. ${ }^{25}$ En este Congreso, además de los delegados coloniales, asistieron los representantes de las seis naciones de la Confederación Iroquesa, bajo la dirección del sachem mohawk Hendrick Tejonihokarawa. Tanto Franklin como los iroqueses apoyaron el plan que buscaba unificar a las colonias inglesas, tomando como modelo a la Liga de los Iroqueses. ${ }^{26} \mathrm{El}$

${ }^{24}$ Las palabras que dirigió el sachem en esa asamblea fueron: "Nuestros antepasados sabios establecieron la Unión y la Amistad entre las Cinco Naciones. Esto nos hizo formidables; esto nos ha dado un gran peso y autoridad con nuestras naciones vecinas. Somos una confederación poderosa, y si ustedes observan los mismos métodos, los que han asumido nuestros antepasados sabios, ustedes adquirirán una fuerza y un poder semejantes. Por lo tanto, pase lo que pase, nunca se separen", http:/iipdigital. usembassy.gov/st/spanish/publication/2009/07/200 90720115214pii0.9292108.html\#ixzz2xKAhI200, consultada el 11 de abril de 2014.

${ }^{25}$ Los estadounidenses a esta guerra la llaman "las guerras indias".

${ }^{26} \mathrm{http}$ ://iipdigital.usembassy.gov/st/spanish/ publication/2009/07/20090720115214p ii0.9292108.html\#ixzz2zgDS9A2h, consultada el plan no se llevó a cabo por la oposición de los representantes del rey; sin embargo, el proyecto sirvió de ejemplo para algunas propuestas durante la Guerra de Independencia de los Estados Unidos. El Plan de Albany situó a Franklin como defensor de la confederación entre los creadores del sistema federalista de su país. En 1751 escribió al periodista y editor James Parker, quien trabajó con él:

Si seis naciones de salvajes fueron capaces de formar un esquema para unirse y llevar a la práctica su unión, de tal forma que ésta ha subsistido durante siglos como algo indisoluble, sería muy extraño que una unión de ese tipo no pueda ser llevada a cabo por diez o doce colonias inglesas. ${ }^{27}$

Esta carta sintetiza la dualidad que muchos ilustrados tuvieron frente a la realidad cultural de "los otros".

\section{EI siglo XIX y las reservaciones indias}

\section{Morgan y la antropología estadounidense}

Una vez concluida la Independencia estadounidense, el proceso de expan-

30 de marzo, 2014. Naturalmente, no sólo procede la estructura confederada del modelo de la Liga iroquesa, que aquí enfatizamos: hay que dar gran importancia también a la tradición política y social puritana, así como al utopismo revolucionario.

${ }^{27} \mathrm{Cfr}$. Bruce E. Johansen, Forgotten Founders, 1982, Harvard Common Press, en www.ratical.com/ many_worlds/6Nations/FF.html. Harvard Common Press en 1982, consultada el 3 de abril de 2014. 
sión territorial se aceleró y se convirtió en una parte sustantiva de la cultura norteamericana, cuya expresión más acabada fue la doctrina del Destino manifiesto, a fin de "extender el área de la libertad". Las alianzas con las tribus indias, que fueron decisivas en el triunfo de los británicos frente a los franceses, ya no eran necesarias. ${ }^{28}$ Las corrientes migratorias de Europa hacia el nuevo país se aceleraron. Los nuevos pobladores venían con sed de tierras para cultivar. Así,

${ }^{28} \mathrm{La}$ unidad política de la Liga Iroquesa empezó a desmoronarse desde la guerra de Independencia de Estados Unidos. Entre 1770-1785 los mohawk, senecas y cayugas apoyaron a los británicos mientras que los oneidas, onondagas y tuscaroras, a los rebeldes independentistas. Los que apoyaron a los ingleses lo hicieron pensando que se respetaría la proclama de 1763, que limitaba la expansión de los blancos sobre los territorios indios. La peste de viruela en 1776 diezmó a los onondagas, lo que aprovecharon los ingleses para celebrar un concejo en Oswego para conseguir la alianza con ellos, aunque los oneidas y senecas siguieron del lado de los estadounidenses. Entonces, John Sullivan dirigió una campaña contra las tribus iroquesas que apoyaban a la Corona británica y quemó 500 casas y muchas cosechas entre 1779 y 1780 . La firma del Tratado de París (1783) en la que los británicos reconocieron la independencia estadounidense no consideró a sus aliados indios a los que abandonó a su suerte. A pesar del apoyo de algunas naciones iroquesas y de numerosas tribus indias a los estadounidenses, ninguna pudo mantener sus territorios originales. El acuerdo de 1763 fue sustituido por la Paz de Fort Stanwix de 1784, que expandió las líneas fronterizas entre indios y blancos, obligando así a los indios a ceder sus tierras y a renunciar a toda reivindicación sobre Ohio, Pennsylvania y el oeste de Nueva York. Con la venta de las tierras indígenas los norteamericanos pagaron parte de su deuda externa. Cfr. John Reed Swanton, The Indian Tribes of North America, 2007, Baltimore, Genealogical Publishing Company, pp. 88-123. surgieron más conflictos con los únicos grupos originarios de Norteamérica, a causa de las violaciones a sus territorios, quienes terminaron por levantarse en armas. Finalmente los indios perdieron y los pocos que quedaron fueron reducidos a reservaciones; así fue como los blancos se apoderaron de más de las tres cuartas partes de los territorios indígenas. ${ }^{29}$

En medio del auge de las concepciones evolucionistas y en el contexto de las teorías dominantes como el darwinismo social ${ }^{30}$ y el spencerismo, ${ }^{31}$ la dualidad ilustrada desapareció y las actitudes racistas, fundamentadas en las ideas de la supervivencia del más apto y la superioridad de ciertos grupos, se incrementaron significativamente; sin embargo, hubo algunas voces disidentes que fundaron la Antropología científica, uno de ellos fue Morgan.

Lewis H. Morgan nació en Aurora, Nueva York y estudió en la Academia Coyunga, en territorio iroqués, donde se hizo amigo entrañable de Ely Parker, de la tribu seneca, quien

${ }^{29}$ Cfr. Howard Zinn, La otra historia de los Estados Unidos, 1999, México, Siglo XXI, pp. 99-114.

${ }^{30}$ La teoría de la evolución de las especies de Charles Darwin fue aplicada por pensadores como Herbert Spencer a todos los ámbitos sociales: económicos, políticos y culturales, distorsionado el sentido original de su autor.

${ }^{31}$ Spencer fue uno de los que iniciaron la sociología; además de evolucionista, también se le considera positivista y materialista. Sus seguidores tuvieron auténticas posiciones eugenésicas. 
lo introdujo en los serios problemas que estaban experimentando los aborígenes en la nueva nación; más tarde estudió derecho en el Union College. El primer caso que llevó, junto con Parker, fue la defensa de las tierras de los iroqueses en un pleito contra una compañía de bienes y raíces que quería arrebatarles una gran porción de su territorio mediante una estafa. Morgan llevó el caso hasta el Congreso, donde lograron ganar el pleito. En agradecimiento, las tribus lo adoptaron con el nombre de Ta-ya-da-o-whu-kuh (puente entre dos pueblos). En 1851 fundó, junto con unos amigos, un club social inspirado en la mitología griega, llamado $L a$ orden del nudo gordiano; posteriormente, la sociedad se transformó en otra, basada en las costumbres iroquesas, a la que bautizaron con el nombre de La gran orden o nueva confederación de los iroqueses. Entre los objetivos del club, además de estudiar a fondo la Liga Iroquesa que se había deshecho desde 1847 cuando los pueblos que la constituían fueron reducidos a reservaciones, estaban las de proporcionar apoyos económicos y legales a los indios seneca de la reserva Tonawanda, cerca de Rochester. En 1851 publicó su primera obra: $L a$ Liga de los Ho-dé-no-sau-nee (iroqueses). En su libro más importante, La sociedad primitiva, ${ }^{32}$ describió

${ }^{32}$ Lewis H. Morgan, La sociedad primitiva, 1972, Bogotá, Editorial Ayuso-Pluma. con todo detalle su teoría de la evolución de la sociedad: desde el salvajismo, pasando por la barbarie hasta llegar a la civilización, cualquier salvaje podía llegar a ser civilizado.

\section{Engels y Marx}

La obra de Morgan influyó profundamente en muchos pensadores decimonónicos, particularmente en Marx y Engels, quienes lo citan y sintetizan continuamente. Engels, en su libro El origen de la familia, la propiedad privada y el Estado, afirma:

Los iroqueses eran un pueblo valiente, vigoroso e inteligente, con un volumen cerebral próximo al promedio de los años. Elocuentes en la oratoria, vengativos en la guerra y de una perseverancia indómita, se han conquistado un sitio en la historia. Si sus proezas militares están empañadas por las atrocidades de la guerra salvaje, ellos han dado prueba de las más elevadas virtudes humanas en sus relaciones recíprocas. La confederación que organizaron debe ser mirada como un notable producto de la sabiduría y de la sagacidad. Uno de sus objetos declarados era el mantenimiento de la paz [...] Merced a su ubicación y poderío militar, ejercieron una notable influencia en el curso de los acontecimientos entre ingleses y franceses, 
en su rivalidad por la supremacía en norteamérica. Como en el primer siglo de la colonización los dos eran casi iguales en fuerzas y recursos, los franceses pueden culpar a los iroqueses en no pequeño grado del derrumbe de sus planes imperiales en el Nuevo Mundo. Para penetrar en el segundo plan de gobierno era necesario sustituir las gentes por municipios y distritos, reemplazar el régimen gentilicio por el territorial. El derrumbe de los gens y el surgimiento de municipios organizados señalan, en forma muy aproximada, la línea divisoria entre el mundo bárbaro y el civilizado, entre la sociedad antigua y la moderna. ${ }^{33}$

Marx decía que la organización política de los iroqueses era el equivalente americano de la democracia ateniense.

Durante el siglo XIX, el racismo entre las poblaciones de origen europeo se incrementó y se manifestó en muchas de las instituciones y costumbres de los blancos estadounidenses, que veían a los negros como esclavos y a los indios como enemigos salvajes a someter, olvidando lo mucho que dependían de ellos. Sólo aparecieron unas cuantas voces disidentes de los profesionales de la antropología.

${ }^{33}$ C. Marx y F. Engels, Obras escogidas, 1971, Moscú, Progreso, t. 3, "El origen de la familia, la propiedad privada y el Estado", pp. 203-352.

\section{Siglo XX y los movimientos de reivindicación cultural}

\section{Gandhi, Fanon y los procesos de descolonización}

En los inicios del siglo pasado una voz no occidental se alzó buscando la independencia de la India. El movimiento de Gandhi duró muchos años, en los que puso el ejemplo con sus ayunos, su pobreza y su paciencia; mostró la fuerza de la resistencia pacífica y defendió la grandeza cultural de su nación. Buscó que la India fuera ella misma y no a imagen y semejanza de Gran Bretaña.

Después de la Segunda guerra mundial y a raíz de los procesos de descolonización, se multiplicaron las voces de los "otros" que reclamaban su libertad y protestaban por el trato injusto que ejercieron sobre ellos los occidentales. Uno de los más famosos fue Frantz Fanon, un psiquiatra, filósofo y escritor, originario de Martinica. Nació en el seno de una familia con antepasados africanos, tamiles y blancos. Años más tarde apoyó al movimiento de independencia de Argelia y se unió al Frente de Liberación de Argel. Sus estudios sobre las psicopatologías de los colonizados son impresionantes; su obra tuvo gran influencia en los movimientos socioculturales y de reivindicación de los derechos civiles. 
Su libro más famoso, Los condenados de la tierra, ${ }^{34}$ fue prologado por Jean Paul Sartre; en él, el filósofo confesó que después de haber participado en la resistencia francesa para liberarse del dominio nazi le era inconcebible apoyar a Francia en su lucha para mantener sus dominios coloniales. Todo el tono del texto muestra una especie de vergüenza por lo que los occidentales hicieron con los colonizados. A diferencia de Gandhi, justifica la violencia de los movimientos libertarios, porque para él son el resultado de la violencia primera ejercida por los colonizadores.

\section{Martin Luther King y el movimiento por los derechos civiles}

Entre 1955 y 1968 muchas personas se unieron en contra de la segregación racial y para exigir la igualdad ante la ley y el acceso a todos los derechos civiles de cualquier ciudadano estadounidense, ya fueran blancos, negros o latinos. La lucha fue larga y dolorosa, con algunas explosiones de violencia; sus principales líderes fueron no violentos, como Martin Luther King, quien fue, al igual que Gandhi, brutalmente asesinado.

${ }^{34}$ F. Fanón, Los condenados de la tierra, 1963, México, FCE, prólogo de J.P. Sartre, trad. del francés Julieta Campos.

\section{Vine Deloria y el movimiento "Alcatraz red power"}

En los años setenta apareció, en Estados Unidos, un movimiento de defensa no sólo de los derechos civiles de los indios, sino también de reivindicación de sus derechos culturales. El autor, teólogo, historiador y activista Vine Victor Deloria, fue un indio siux que participó en el movimiento Poder rojo de Alcatraz, ${ }^{35}$ fue director ejecutivo del Congreso Nacional de los Indios Americanos y miembro del Museo Nacional de los Indios Americanos, que tiene sedes en Washington D.C. y la ciudad de Nueva York. Fue profesor en la Universidad de Arizona, donde inició el primer programa de Estudios sobre los indios americanos; también fue profesor en la Universidad de Colorado y en la Escuela de Leyes de Arizona. Su obra más famosa se titula Custer died for your sins. An indian manifesto ${ }^{36}$ en donde critica a la cultura occidental porque no vincula el conocimiento con la moral, sino que más bien conecta al poder con el conocimiento y los hace

${ }^{35}$ Llamado así cuando activistas indígenas estadounidenses tomaron la isla de Alcatraz, donde se localizaba la paradigmática cárcel, y la ocuparon durante 19 meses en 1969, convirtiéndola en un símbolo del Poder Rojo.

${ }^{36}$ Vine Deloria Jr., Custer died for your sins. An Indian Manifesto, http://www.feminish.com/wpcontent/uploads/2012/08/Custer_Died_for_Your_ Sins.pdf, consultado el 20 de marzo de 2004. 
equivalentes. El manifiesto sostiene que es necesario devolver la autonomía a las comunidades indígenas y denuncia el imperialismo cultural de la sociedad blanca occidental que se impone y desprecia a las otras culturas.

\section{La liga iroquesa y la democracia estadounidense}

\section{El bicentenario de la Constitución de los Estados Unidos de América}

En 1987, en el marco de las celebraciones de los doscientos años de la Constitución estadounidense, el Programa de Estudios sobre los Indios Norteamericanos de la Universidad de Cornell organizó el seminario Los Iroqueses, la Gran Ley de Paz y la Constitución de los Estados Unidos, en el que participaron unas doscientas personas, entre estudiantes y académicos. Ahí se discutió acerca de la posible y olvidada influencia de las naciones indias en la elaboración de la Carta Magna estadounidense. En este seminario se mostraron diversas evidencias según las cuales la Confederación Iroquesa aportó elementos sustantivos al sistema político norteamericano y a su Constitución.

Entre las ideas que se sostuvieron en este Congreso están las que planteó el doctor Grinde, del Gettysburg
College, resumen de lo que la mayoría de los participantes dijo:

La democracia moderna se estableció primero en América y no es el resultado de las teorías políticas europeas. La democracia estadounidense le debe su sello distintivo a los principios y la estructura de los gobiernos civiles de los indios. La Gran Ley de Paz instauró un gobierno de la gente, para la gente, por la gente. ${ }^{37}$

El mismo profesor sostuvo que Thomas Jefferson se inspiró en los símbolos de la leyenda del Peacemaker (pacificador) quien logró establecer el camino de la paz en medio de las sangrientas guerras tribales y, como símbolo de la Gran Ley de Paz, se dibujó un gran pino cuyas ramas se extienden para cobijar a todas las naciones que se comprometieran con ella; encima del pino se posa un águila.

${ }^{37}$ Donald A. Grinde Jr. y Bruce Elliot Johansen, Exemplar of Liberty: Native America and the Evolution of Democracy. A definitive study of how the founders of the United States combined European, American and Indian Ideas into a new political system, 1991, American Indian Studies Center, Angeles University. Estos autores sostienen que, entre los elementos de la organización iroquesa que influenciaron al sistema nortemericano están, por ejemplo, la idea de soberanía de cada estado y la unión confederada; la prohibición para los legisladores de participar en la guerra; y la separación entre los poderes civiles y militares, conceptos que no existían entonces en Europa. Tampoco tenían un mandato hereditario y sus naciones podían naturalizar y admitir a nuevos miembros. Existía el derecho de impugnación y las mujeres podían ser elegidas. 
Jefferson transformó el pino en el árbol de la libertad y el águila se sustituyó por las trece flechas que representan al nuevo gobierno estadounidense.

Algunas ideas parecidas fueron presentadas en otro libro del profesor Bruce Johansen, Forgotten Founders ${ }^{38}$ donde se muestran indicios de cómo Benjamín Franklin, Thomas Jefferson y otros de sus contemporáneos se inspiraron en las ideas políticas y sociales de los iroqueses y sus instituciones. También muestra cómo algunas de ellas se combinaron con la herencia cultural de los colonos europeos, lo que produjo una nueva realidad. Al principio del libro, Johansen transcribió la siguiente cita de Lewis $\mathrm{H}$. Morgan:

Las seis naciones mantienen prácticamente la misma relación con la liga iroquesa que los estados americanos tienen con la Unión [...] Todo su sistema político era contrario a la concentración de poder en las manos de cualquier persona individual, y proclive al principio de división de poderes entre numerosos iguales [...] La confederación iroquesa contiene los gérmenes del Congreso, del Parlamento y de la legislatura moderna. ${ }^{39}$

${ }^{38}$ Bruce E. Johasen, Forgotten founders. Benjamin Franklin, the Iroquois and the Rationale for the American Revolution, en http://www.ratical. org/many_worlds/6Nations/FF.pdf, consultada el 30 de marzo 2004.

${ }^{39}$ Ibid., cap. I, p. 3.
Algunos piensan que el reconocimiento de los aportes de las distintas minorías a la historia de Estados Unidos se enmarca dentro de las corrientes del multiculturalismo, apoyadas por la ONU desde 1982, cuando se iniciaron los trabajos que culminaron en la Declaración de los Derechos de los Pueblos Indigenas de 2007 y en las políticas multiculturales de la educación oficial norteamericana. Sin embargo, como se puede apreciar a lo largo de este breve artículo, el reconocimiento de los otros no es nuevo, tiene antecedentes en los escritos de la mayoría de los misioneros del siglo XVI; en las ideas que, desde finales del siglo XVII y durante el siglo XVIII, inspiraron a muchos ilustrados; y en los escritos de importantes antropólogos del siglo XIX. El racismo tampoco es nuevo, pero los grandes genocidios y fundamentalismos intolerantes del siglo XX tuvieron proporciones inauditas y mostraron que las posturas que acogían a los otros o fueron olvidadas o no tuvieron la fuerza y aceptación suficiente para contrarrestarlos. La mayoría de los antropólogos de la primera mitad del XX creían que desarrollo era sinónimo de occidentalización: había que transformar a los otros a la imagen y semejanza de los civilizados occidentales y, en este sentido, las posturas disidentes tuvieron poco eco; la unidad 
se entendía como homogeneidad cultural. Entonces, los otros levantaron sus voces para liberarse del dominio colonial o para exigir la igualdad ante la ley, como lo hicieron los movimientos de derechos civiles o para defender sus identidades y modos de ser, exigiendo el respeto a sus culturas ancestrales. Así, se pusieron otra vez en el centro del debate las relaciones interculturales, como en la época de la Ilustración. Se hizo patente que todos hemos recibido influencias unos de otros y que somos deudores, en muchos aspectos, de las culturas no occidentales. Todavía nos falta mucho para entender que todos estamos involucrados en el proceso de ir construyendo a la humanidad y en lo que significa el respeto a la dignidad de los otros y la de nosotros mismos, en la apasionante y compleja tarea de construir la unidad humana en medio de nuestra diversidad. 
CITAM Derechos Reservados.

La reproducción total o parcial de este artículo se podrá hacer si el ITAM otorga la autorización previamente por escrito. 


\section{EL IMPACTO DE LAS NUEVAS TECNOLOGÍAS EN LAS PERSPECTIVAS DEL PAISAJE \\ Liliana Quintero*}

\section{THE IMPACT OF NEW TECHNOLOGIES \\ ON THE NOTION OF LANDSCAPE}

RESUMEN: El concepto de paisaje ha cambiado, se ha hecho más amplio gracia a la tecnología, transita de lo natural a lo artificial. Y más allá de la pantalla surge la arquitectura cyborg: dispositivos digitales como plataforma creativa; una nueva experiencia, el no-lugar, pero también nuevos riesgos.

PALABRAS CLAVE: paisaje, pantalla, dispositivos digitales, no-lugar, intervención.
ABSTRACT: The concept of landscape has changed. Becoming more extensive due to technology, it evolves from the natural to the artificial. And from beyond the screen emerges cyborg architecture: digital devices utilized as creative platforms: a new experience, the non-place, as well as new risks.

KEYWORDS: landscape, screen, digital devices, non-place, intervention.

RECEPCIÓN: 28 de enero de 2014.

ACEPTACIÓN: 12 de diciembre de 2014.

* Facultad de Filosofía y Letras, UNAM. 


\section{EL IMPACTO DE LAS NUEVAS TECNOLOGÍAS EN LAS PERSPECTIVAS DEL PAISAJE}

Reflexionar acerca del paisaje se torna problemático, ya que cuando nos referimos a éste, en abstracto, resulta difícil definirlo. El paisaje implica un componente humano, un observador, pero también implica un territorio determinado. Desde la óptica de la geografía se observa una relación de tierra, de cierta organicidad que se vincula con el ojo de un espectador, de un habitante. El término Landscape, se traduce como una forma de tierra, una forma de suelo. ${ }^{1}$ Pero, ¿qué sucede cuando ese suelo se escapa de los límites físicos? Finalmente el paisaje es un concepto y ya no podemos hablar de un paisaje totalmente natural, siempre existe una fisura técnica que impregna sus elementos y brotan huellas de artificialidad. ${ }^{2}$

Pero en nuestro imaginario, cuando hablamos de paisaje se refleja el espíritu que nos heredaron los románticos y se abre un interés por rescatar la idea que encierra el paisaje natural; nos intriga porque representaba la otredad, el inconsciente, el impulso, el misterio, la fuerza creadora, el Sturm und Drang. ${ }^{3}$

${ }^{1}$ Carl O Sauer, "La morfología del paisaje”, 2 de junio 2013 (http://polis.revues.org/5015).

${ }^{2}$ Concepto usado por Fernando Broncano y Jorge Linares.

${ }^{3}$ Concepto utilizado por los románticos como ruptura frente al dominio de la razón, se traduce como tormenta e ímpetu. 


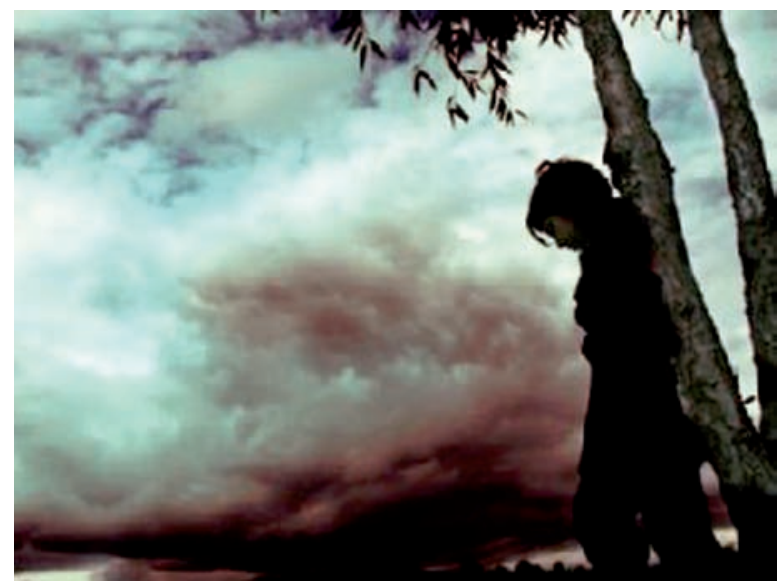

En este sentido, Amaranta Sánchez retoma la mirada romántica, en homenaje, y crea la obra Sturm und Drang, en la que observa desde otro ángulo y retoma el paisaje, pero con el interés de modificar lo estable y así interviene el espacio orgánico para dislocarlo en un espacio onírico; la mirada de la artista reflexiona en elementos como la luz artificial, la imagen invertida, el pliegue repetitivo, el brote de nostalgia y el guiño de tempestad, los cuales se manifiestan como componentes que rompen una estructura lógica para revelar que lo que vemos no es un paisaje, es ficción, que nos remite una búsqueda sobre un paisaje que ha quedado perdido.

\section{Paisaje a-biótico/la mediatización del entorno}

El ser humano es sin duda un animal que se distingue por su manera de crear interfaces, algunos dicen que el lenguaje es la primera interfaz. El humano se define desde su mediación artefactual. Siempre hay algo en medio que le permite interactuar con el entorno; sin duda, esa mediación no sólo es un instrumento que facilita su acontecer, sino que se vuelve parte del mundo, es real, pero tiene una característica primordial, su virtualidad. Aristóteles señaló que lo potencial estaba en estrecha relación con lo actual, que la semilla era potencialmente árbol y que en ésta yacía toda la esencia de llegar a ser actual. Pero Aristóteles no pudo imaginarse que la potencia se materializaría en un estado intermedio. Las cosas se quedan en estado- 
semilla, pero con una posibilidad ficcional, de imagen, en estado numérico, en código, pero quizá el código es su estado actual, lo problemático es que eso se vuelve invisible, porque lo que vemos son imágenes. En la actualidad la virtualidad está adquiriendo un estatus mayor que el estado real y es porque "lo virtual puede ser también una propiedad de la realidad (y de sus objetos físicos)". ${ }^{4}$

Se convierte la realidad, como afirma José Ramón Alcalá, "en algo que nos impide tropezarnos físicamente con ella". ${ }^{5}$ Se despliega de manera fantasmagórica, pero necesita de un artefacto con la cual se agencie, se haga cómplice: la pantalla.

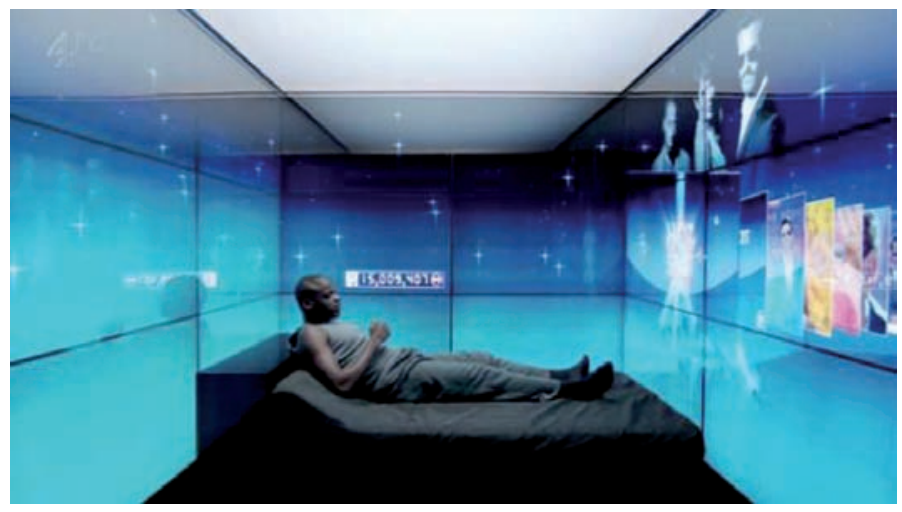

Las pantallas se han convertido en superficies de captura, de escape. Pero, ¿por qué nos resultan tan agradables? De alguna manera, se vuelven ventanas que han sustituido la contemplación del paisaje. Muchas de las ciudades contemporáneas borran sus fronteras con el paisaje natural y han sido invadidas por superficies mediales.

Tokio es un buen ejemplo de una ciudad medial. Japón se integra muy bien al ciberespacio, por un lado la manera en como Oriente concibe el concepto de espacio, y el otro, que "después de la bomba atómica quedaron orillados a huir al mundo virtual, otaku, en una de sus acepciones significa quedarse en casa, y así lo llevaron a cabo, se quedaron en casa envueltos entre el televisor, los videos y los ordenadores". ${ }^{6}$

${ }^{4}$ José Ramón Alcalá, Ser digital. Manual de supervivencia para conversos a la cultura electrónica, 2009, Santiago, AV Ediciones del Departamento de Artes Visuales, p. 17.

${ }^{5}$ Idem.

${ }^{6}$ Marc Augé, "Sobre modernidad: del mundo tecnológico de hoy al desafío esencial del mañana", Dênis de Moraes, (coord), Sociedad mediatizada, 2007, Barcelona, Gedisa, p. 127. 


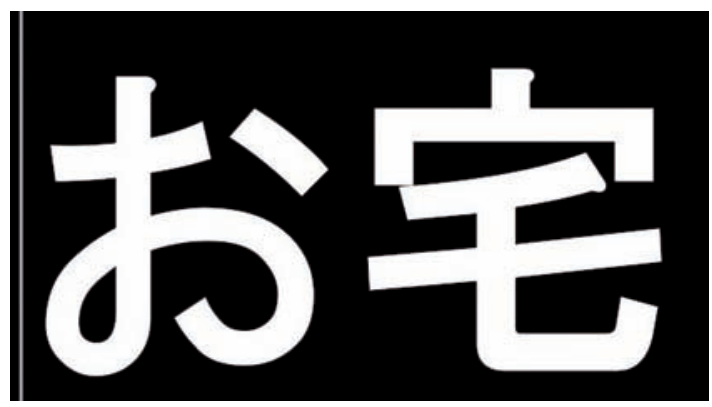

Hervé Le Bras afirma que vivimos en "la era de la extensión urbana". ${ }^{7}$ Las ciudades crecen y se tragan el paisaje, creando horizontes distorsionados, llenos de ruido, de contaminación visual, nos invaden las pantallas publicitarias: en el metro, en la calle, en los bares, en el tránsito; y no contentos con ello, cada individuo huye de la cartografía pantalicus ${ }^{8}$ abriendo su propia ventana personal desde un teléfono, un iPod, un iPad, una iTablet, un ordenador, un PSP, un android o unos google glass.

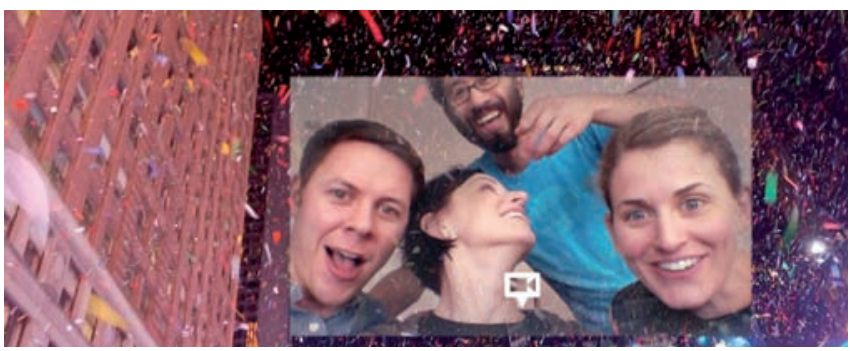

El problema de las pantallas es que no las controlamos, aparecen, se despliegan, las portamos a todo momento, y a su vez, ellas nos portan.

Quizá una manera de huir de las pantallas es la intervención estética, una pieza sugerente es

The Artvertiser ${ }^{9}$ de Julian Oliver, dispositivo de visualización que permite reemplazar (virtualmente) el contenido de un cartel o valla publicitaria por cualquier otro que se desee (imágenes, vídeo). En primer lugar, el artista

${ }^{7}$ Marc Augé, op. cit., p. 130.

${ }^{8}$ Término utilizado por Lipovetsky y Jean Serroy, refiriéndose al homo pantalicus, en Gilles Lipovetsky y Jean Serroy, La cultura-mundo, 2010, Barcelona, Anagrama, p. 85.

${ }^{9}$ Julian Oliver, The Artvertiser, 2008. 
NOTAS

"enseña" al ordenador a reconocer determinados anuncios como espacios a ser intervenidos y posteriormente invita a otros artistas a crear contenidos para aplicarlos en el lugar predefinido. Por medio de un dispositivo de visualización, se pueden observar dichos espacios intervenidos. El artista habla en este proyecto de "realidad mejorada", más que "aumentada", puesto que su proyecto intenta contrarrestar la invasión del paisaje urbano por parte de las corporaciones. ${ }^{10}$

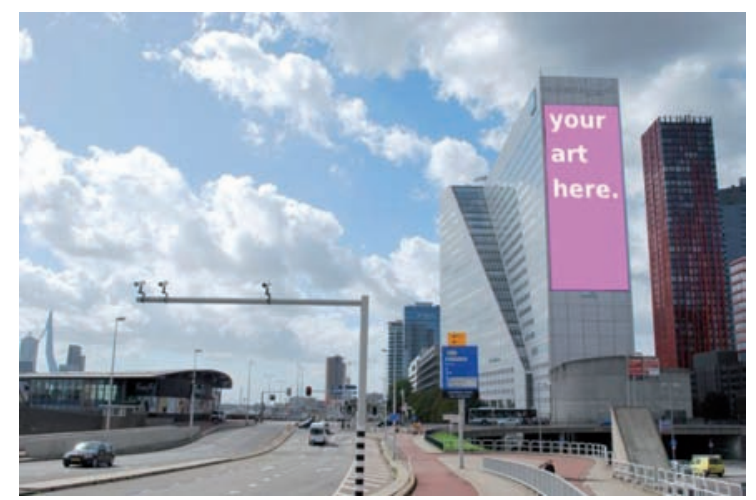

Otra manera de intervención-acción es lo que realiza el colectivo Kònic Thtr:

Una de sus obras, Before the beep, pieza escénica, hace referencia a los cambios de la percepción humana en la comunicación interpersonal mediada por las nuevas tecnologías y a los espacios que esta mediación genera. La pieza confronta el cuerpo con estas mismas tecnologías mediadoras de la comunicación y explora cómo éstas re-escriben el cuerpo y cambian nuestra comprensión de lugar y la idea de presencia, redefiniendo narrativas e individuos. Before the beep se despliega como una membrana tecnológica que ofrece al público lecturas de la comunicación contemporánea. ${ }^{11}$

${ }^{10}$ Información extraída del sitio oficial de Julian Olivier: The artvertiser: improved reality, 2 de junio 2013 (http://theartvertiser.com/) (La traducción es mía).

${ }^{11}$ Información extraída de Antic Teatre, 2 de junio 2013 (http://www.anticteatre.com/arxius/ Programacio_anual_2011/2011_abril_index.html). 


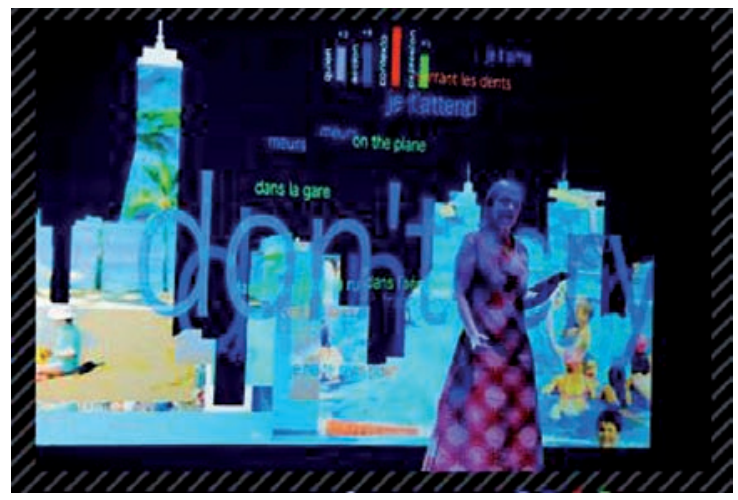

Son dos piezas que nos invitan a reflexionar sobre la exacerbada medialidad de la realidad contemporánea, las dos habitan a los dispositivos tecnológicos desde lo interno, generando reflexiones estéticas, en las que el componente visual es indispensable.

Más allá de la pantalla. Arquitectura-cyborg. Los dispositivos digitales como posibilidad de una plataforma creativa

Internet se ha convertido en un espacio relevante en la actualidad, principalmente las generaciones de adolescentes y jóvenes transitan el mayor tiempo en las atmosferas digitales o se encuentran en el pliegue fronterizo entre las dos. Habitan los dos espacios simultáneamente.

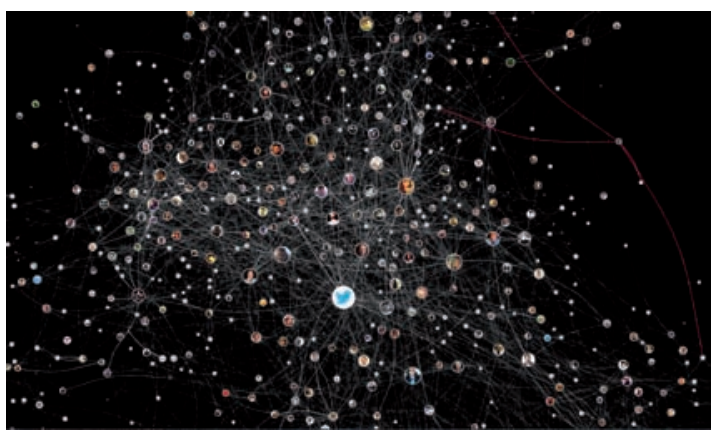


NOTAS

Remedios Zafra en su libro Un cuarto propio conectado reflexiona precisamente en la manera como habitamos el mundo contemporáneo, cuáles son los límites de nuestro espacio y plantea que "ya no son sólo espacios materiales, sino hablamos de una prolongación de la pantalla y su versatilidad de ser un mismo escenario para usos diversos". ${ }^{2}$

En este sentido es a lo que José Pérez Lama ${ }^{13}$ se refiere como arquitectura cyborg, aquella que integra los dos espacios: el físico con el virtual, haciendo múltiples relaciones. Aunque se vuelve un tanto paradójico ya que uno tiene una naturaleza mental, transitoria y no es capaz de soportar o contener arquitectura. "Una página web [...] no ofrece soporte para el cuerpo". ${ }^{14}$

\section{Advertencia}

Me gustaría integrar una reflexión que Derrick de Kerckhove en su libro La piel de la cultura ${ }^{15}$ advierte, dice que el ideograma japonés MA tiene cierta similitud en la manera como se desplaza el concepto de espacio en el ciberespacio, generándose una espacie de fusión entre espacio y tiempo del mismo modo que el concepto japonés, ya que MA es espacio-tiempo no hay una separación, pero también se pueden referir de manera separada al tiempo, y al espacio.

La palabra MA parece a primera vista vaga pero es la multiplicidad de significados y al mismo tiempo lo conciso de una sola palabra lo que hace de $m a$ un término conceptual único sin paralelo en otros idiomas. [...]

MA es importante no solo como una idea abstracta, sino también como un elemento estructural concreto. Para los japoneses es esencial considerar a la mayoría de las composiciones como si estuvieran integradas de una parte expresiva y una parte vacía. ${ }^{16}$

\footnotetext{
${ }^{12}$ Remedios Zafra, Un cuarto propio conectado, 2010, Madrid, Forcala, p. 40.

${ }^{13}$ José Ramón Alcalá, La piel de la imagen, 2011, Valencia, Sedemà, p. 144.

${ }^{14}$ Alcalá, Ser digital, op. cit., p. 99.

${ }^{15}$ Alcalá advierte esta referencia en ibid., p. 130.

${ }^{16}$ Kunio Komaparu, “Teatro Noh: Principios y Perspectivas”, en Artes escénicas del japón, 2 de junio 2013 (http://www.japonartesescenicas.org/teatro/generos/simbologiadelnoh7-1.html).
} 


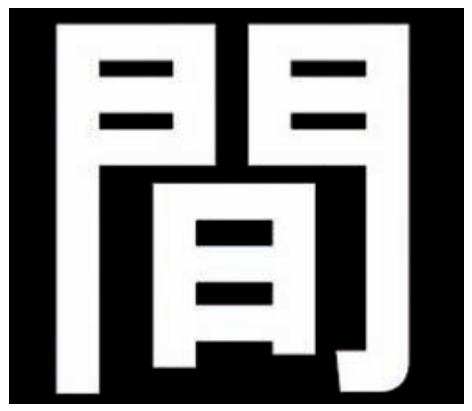

\section{Fin de la Advertencia}

De esta manera, podemos hacer una analogía del paisaje contemporáneo como una suerte de integración del espacio físico y el virtual. Vivimos las dos esferas de realidad, pero no somos conscientes. Es más fácil develarlo bajo la óptica de los artistas, por ejemplo:

El colectivo Les Liens Invisibles realiza proyectos en los cuales les interesa intervenir los espacios y hacen uso de los medios digitales para integrar esferas virtuales en lugares concretos. Una de sus obras consiste en invitar a diversos artistas a crear "pabellones virtuales" que se colocaron en los espacios reservados a los pabellones reales de la Bienal de Venecia (los Giardini) y en la Plaza de San Marcos. El proyecto se presentó como una "experiencia de realidad aumentada no invitada, experimental y alucinatoria". ${ }^{17}$

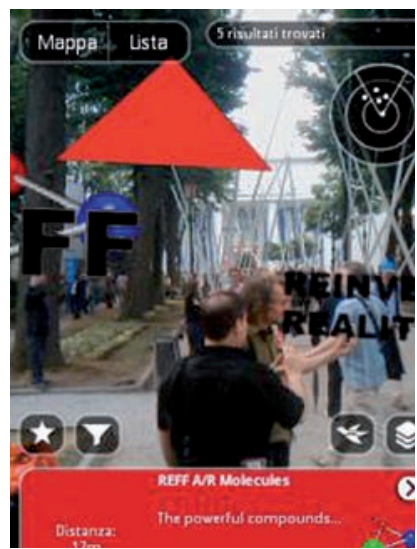

${ }^{17}$ Información consultada del sitio oficial de Les Liens Invisibles: 2 de junio 2013, (http://www. lesliensinvisibles.org/) (La traducción es mía). 
Los dispositivos digitales permiten una nueva forma de experiencia, implican una mediación, pero la mediación se convierte en la experiencia relevante, uno va a un sitio y ya no importa la presencia física, sino lo que interesa es la apariencia, la foto adquiere una nueva modalidad: ya no es la foto del recuerdo, la foto ya no implica un pasado, sino es el instante eterno del presente, del escenario cambiante. Los conciertos, los no-lugares, los lugares, cualquier reunión implica una conexión con un espacio-íntimocolectivo de un perfil, de un perfil establecido, acartonado siempre, muestra el mejor ángulo. No cabe la tristeza, no caben los fluidos corporales, no cabe el tacto, no cabe el cara a cara.

El no lugar, como lo llamo Marc Augé, se ha convertido en la estancia favorita de los individuos contemporáneos. Las ciudades se edifican bajo una lógica homogénea desplazando cada vez más a los lugares, los espacios simbolizados, aquellos espacios que para la antropología nos identificaban, lo que nos permitía reconocernos como comunidad. ${ }^{18}$ Ahora nos reconocemos en la pantalla de internet, somos una multitud conectada, pero destinada a habitar un no-espacio, un espacio líquido. ${ }^{19}$ Hemos perdido interés por movernos y tomar conciencia de un territorio, ocupar un paisaje, navegarlo, caminarlo, construirlo. Somos habitantes del ciberespacio, pero nunca podrá ser un "territorio de reconocimiento, ahí no podremos leer en parte en su totalidad la identidad de los que lo ocupan". ${ }^{20}$

164 Pero siempre se generan grietas, fisuras en las cuales podemos intervenir de otra manera. En este sentido, podemos iniciar una nueva forma de entender el espacio-tiempo fundado desde el ciberespacio. Aunque el paisaje virtual nos habita, nos pone a circular bajo su lógica. Uno de los problemas es que el mundo virtual oculta su materialidad y refleja una distinta; en este sentido es necesario que actúe la mirada del especialista, la intervención artística-tecnológica. Hoy en día "dichas extremidades corporales están también protésicamente digitalizadas en nuestro cerebro". ${ }^{21}$ Quizá ese sea el mayor problema, hemos creado un dispositivo que difícilmente vamos a poder quitar, borrarlo. Günther Anders advirtió que el problema era que "la producción técnica ha situado en las antípodas la reproducción natural de la vida, y que se ha vuelto un proceso ciego y no calculado, Prometeo

${ }^{18}$ Cfr., Marc Augé, op. cit.

${ }^{19}$ Conceptos utilizados por José Ramón Alcalá, en los cuales se refiere al espacio virtual. Cfr. La piel de la imagen, op. cit.

${ }^{20}$ Ibid., p. 129.

${ }^{21}$ Idem. 
se siente orgulloso de sus objetos técnicos, pero avergonzado de sí mismo, los objetos técnicos lo han humillado".22

Me surge una inquietud al recordar cuando mi hijo me preguntó, al ver un documental sobre animales, que si el animal que veía era verdadero o estaba hecho por computadora.

Respondí con cierta preocupación: "por supuesto que es real". Pero algo me intrigaba en esa pregunta, los niños y los jóvenes de esta generación tienen una cercanía mayor con lo virtual; pero ahora el paisaje natural se ha remplazado y se pone en duda si es real. De hecho, podemos observar ahora animales extintos que los documentales nos presentan, bajo un marco pseudocientífico, seres inexistentes que sólo pueden ser reconstruidos desde la memoria, la ciencia y la imaginación, y otros futuros que presentan hipótesis de fantasía. Sabemos que son virtuales, pero nos interesa ver lo imposible, aunque sólo desde el ámbito aparente. Habrá que preguntarnos honestamente si el mundo que hemos diseñado es tan aterrador que no nos queda más que refugiarnos en su estado virtual, o en el inter, en medio de los dos; pero no será esto un engaño más, porque el paisaje aún palpita.

Así, nos muestra Eiija Liisa Athila su pieza Horizontal, en la que activa la majestuosidad de un abeto; el sonido de las hojas movidas por el viento nos obliga a conectarnos con el paisaje natural, pero al clavar la mirada en las hojas nos enfrentamos a la verticalidad del árbol, lo cual nos estorba, nos confronta y nos recuerda que es una pantalla; también sugiere que la mirada no necesariamente tiene que estar siempre desde la lógica arborescente, pudiera tal vez generarse de manera rizomática.

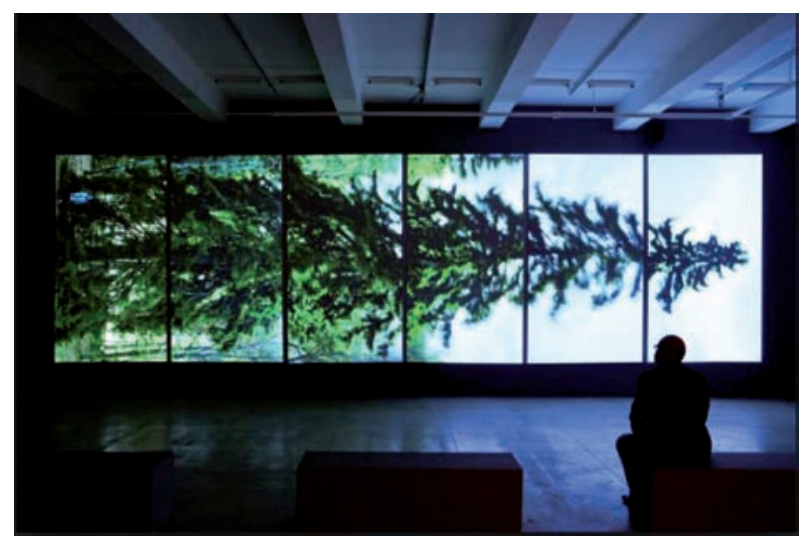

${ }^{22}$ Jorge Linares, Ética y mundo tecnológico, 2007, México, FCE/UNAM, p. 201. 


\section{Paisaje bioartefactual. Límites contemporáneos de inter/vención}

Se habló ya de la intervención medial, de pantallas, de unos y ceros, de imagen, de experiencias fantasmagóricas, de cómo se integra lo virtual en nuestro entorno; me gustaría dibujar un pequeño esbozo de la intrusión tecnocientífica en el paisaje contemporáneo y lo planteo porque la exposición Panorámica lo sugiere como límite final o como otro punto de partida. La pieza de Plantas nómadas de Gilberto Esparza lo advierte.

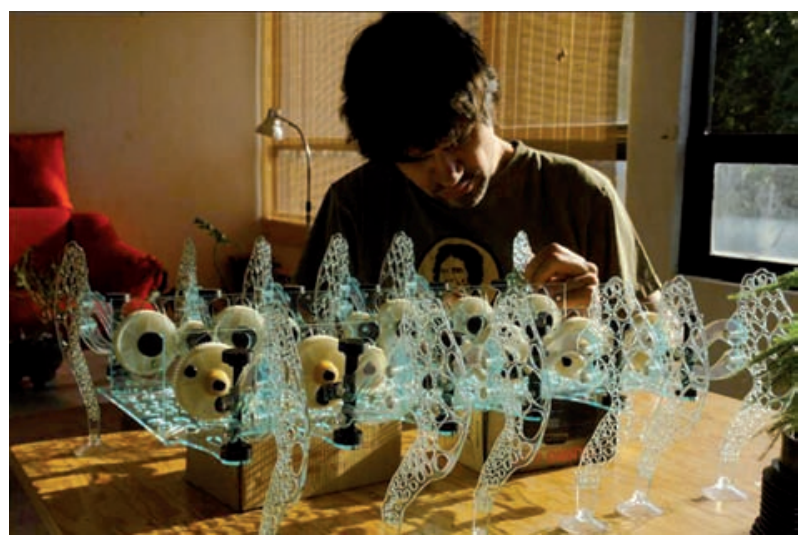

En el entorno contemporáneo, las prácticas tecnocientíficas han desplazado la manera científica de la modernidad y toman como herramienta ejecutante los medios computacionales; esto da como resultado que el dispositivo actúe desde lo íntimo, desde el manejo de información, lo cual modifica de manera molecular, genética e informacional, los elementos vivos. La biotecnología se distingue como la ciencia del siglo XXI, toda la intervención se justifica desde parámetros comerciales y científicos. Robert Carlson reflexiona que la intervención hacia elementos vivos se hace desde parámetros ingenieriles y se van ensamblando como legos: "La ciencia nos ha llevado al punto donde estamos aprendiendo a controlar los elementos moleculares de la vida y el flujo de información entre ellos". ${ }^{23}$

\footnotetext{
${ }^{23}$ Robert H. Carlson, Biology is technology, 2010, Cambridge, Harvard University Press, p. 15 (La traducción es mía).
} 
Otra propuesta interesante es la pieza Desmodium Máquina realizada por el Media lab del Centro Multimedia; es una pieza que intenta rescatar el inconsciente de una planta, a partir del sensado de un ecosistema de plantas que mide la catidad de $\mathrm{CO} 2$, teniendo como factores de intervención la humedad y la temperatura. El ecosistema se comunica con un brazo robótico que, dependiendo de los factores de estímulo, genera una graficación en un disco de cobre. La intención es mostrar, de manera metafórica, la respiración de las plantas, generando una gráfica a partir de las técnicas del grabado. De manera poética, al colectivo del Media lab le interesaba transgredir y poner sobre la mesa la forma en como se trata el entorno natural pero, a su vez, usar un elemento intangible, como la respiración, y un elemento concreto, el oficio tradicional del grabado, proponiendo un paisaje visual que personifica la vida.

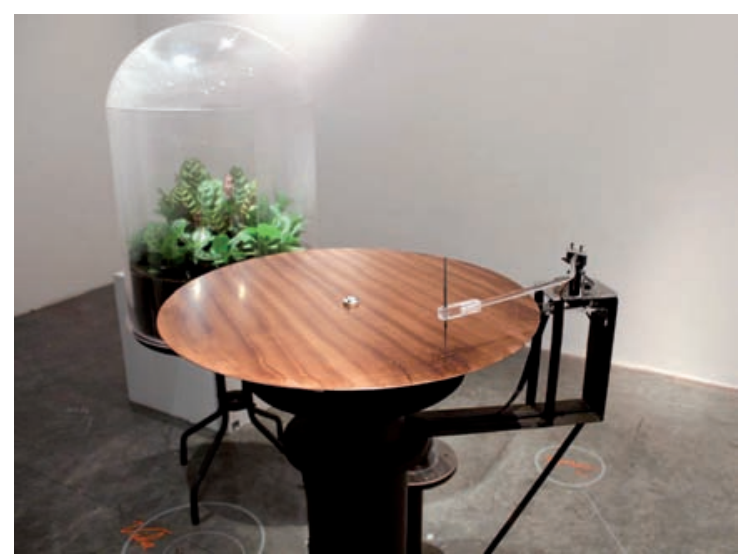




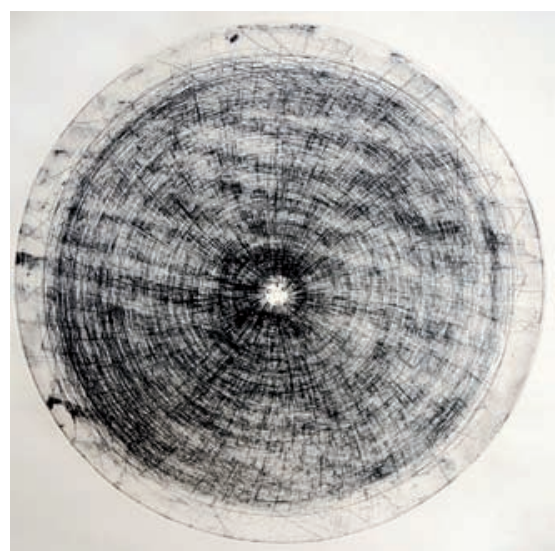

Las prácticas artísticas nos permiten ver lo invisible, pero eso no es suficiente. La tecnociencia se vuelve un dispositivo transgresor que interrumpe, que inter-media el paisaje orgánico, pero la inter-mediación yace invisible. Los laboratorios se tornan en la actualidad como entornos proyectivos para las nuevas especies. Queda claro entonces, que la artificialidad se ha vuelto desproporcionada. Es el momento de apagar nuestras prótesis, nuestras supuestas conexiones y retomar nuestra mejor herramienta, la imaginación; hagamos silencio con ella y tratemos de dibujar-tocar un mundo, un espacio, un lugar, un paisaje posible, aquel que no está en el futuro, pero sí está por venir. ${ }^{24}$
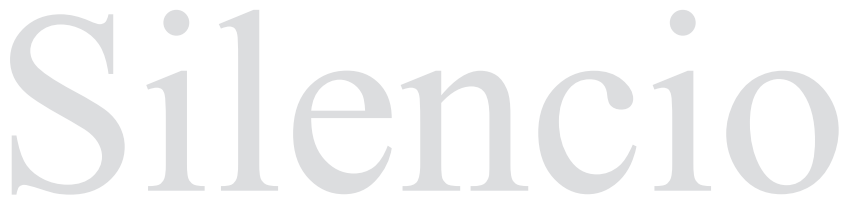

${ }^{24} \mathrm{~A}$ manera de juego y referencia retomo el concepto de por venir de Jacques Derrida, quien distingue el futuro que es algo predecible y lineal, a diferencia del por venir, que es totalmente nuevo; se puede confrontar en: https://www.youtube.com/watch?v=CtcpwJCC6Co. 


\section{RESEÑAS}

Patricia Funes, Historia mínima de las ideas políticas en América Latina, 2014, México, El Colegio de México, 282 pp.

RECEPCIÓN: 15 de octubre de 2014.

ACEPTACIÓN: 21 de noviembre de 2014.

L

eal a su título, este texto postula que existe un espacio cultural definido llamado América Latina que presenta, desde el siglo XVIII hasta la segunda mitad del XX, conspicuas e indiscutibles afinidades. No pocos investigadores, tendencias y estudios han levantado, sin embargo, interrogantes y reservas a este aserto, especialmente en términos económicos y culturales. Señalan, por ejemplo, discursos y actitudes que en esto días se verifican en países como Venezuela o Bolivia, pero que son sustancialmente divergentes de los que presiden a Chile o México. Y cuando algunos estudiosos indagan en lo ocurrido en la región en las décadas pasadas, puntualizan que los ensayos de complementación de mercados que se iniciaron en este espacio desde los sesenta del transcurrido siglo, no han traído a la fecha frutos apreciables. Y en verdad, múltiples pasos con este rumbo fueron desandados, afilando las disparidades entre los países de la región. No obstante, y sin invalidar estas objeciones, tiene fundamentos postular que hasta la mitad del siglo XX las convergencias entre ellos fueron importantes, y que en la dinámica e intercambio de ideas que hoy se verifican en el área, las afinidades -reales o imaginariascontinúan siendo conspicuas, debido a una compartida memoria histórica y a un lenguaje que, más allá de sus matices locales, contiene rasgos compartidos. Esbozar una revista de ellas es el propósito cardinal de este libro.

Patricia Funes inicia sus indagaciones subrayando la ruptura del vínculo colonial del espacio latinoamericano con España en el siglo XIX y la cristalización consiguiente de entidades nacionales que, al superar múltiples y ásperas fricciones dentro y entre ellas, preservaron sin embargo significativas afinidades en los procesos de formación de las identidades colectivas. La autora apunta que "en las colonias españolas, hacia finales del siglo XVIII, 
la frase nuestra América ganó difusión al gestar espacios que incluyeron a los sectores criollos" (p. 17). Más aún: éstas escogieron el adjetivo americanos para definir la singular identidad.

En este esperanzado amanecer, Simón Bolívar postuló la unidad esencial de las naciones latinoamericanas en razón de la "comunidad de origen, lengua, costumbres y religión" que entonces las caracterizaba. Cómo imprimir a esta predicada afinidad contenidos y aspiraciones similares será, desde entonces, la compartida aspiración de líderes locales quienes, al dibujar los rasgos singulares de sus territorios, no impugnaron el peso de compartidas herencias (p. 34). Así, se constituyó un archipiélago de países que no ignoró las mutuas afinidades entre ellos; con el andar del tiempo, tendencias centrífugas lesionaron el ambicioso proyecto bolivariano; en su lugar, cristalizó una pluralidad de entidades colectivas separadas por celosas fronteras y élites dominantes, amén de la configuración de singulares historiografías nacionales que las justificaron. Funes señala algunos factores de este tránsito: la ruralización y militarización del poder, la disolución del aparato administrativo colonial, los ajetreos de las élites económicas tradicionales, las rivalidades entre caudillos militares y las ambiciones de naciones foráneas interesadas en reemplazar el dominio ibérico (p. 41).

Orden, estamentos jerárquicos, centralización: tendencias y hechos dominantes que no se reflejaron en la letra-mucho menos en el espíritu-de las constituciones nacionales; apegadas a arquetipos europeos, éstas pusieron formal énfasis en temas como la división de poderes, las garantías civiles, los derechos a la propiedad, enunciados que apenas frenaron las propensiones autoritarias de caudillos y élites. Naturalmente, también se registraron diferencias en el estilo y en la letra de los enunciados constitucionales. Dice Funes con acierto: "no puede trazarse un itinerario unívoco del liberalismo, republicanismo y democracia en toda América Latina" (p. 46). Cada país instituyó formas peculiares de autodefinición y desenvolvimiento colectivos. Argentina, por ejemplo, alentó la recepción de migrantes europeos, suponiendo que éstos difundirían un espíritu empresarial afín y propicio que habría de animar el progreso económico; no confiaban sus gobiernos ni en el roto ni en el gaucho como actores dinámicos de la modernización nacional. En contraste, México prefirió apoyarse en sus propias élites urbanas, desentendiéndose de la lacerante explotación que ellas imponían a los sectores indígenas; en no pocos casos, las inclinaciones gubernamentales en favor del legítimo y necesario monopolio de la violencia llevó a este país a restringir el poder doctrinario y real de la Iglesia católica, poco inclinada a la sazón a una modernidad liberal (p. 50). 
Por su parte, Uruguay alentó importantes avances en la secularización de las instituciones, que se manifestaron en la ampliación de los derechos ciudadadanos, incluyendo la sanción laica de matrimonios y divorcios. En contraste, los gobernantes de otros países negociaron compromisos con el poder eclesiástico y militar. Allende estas discrepancias, en la mayoría de los casos la consigna comteana Orden y Progreso se impuso en el rumbo político de los emergentes Estados nacionales.

Los siguientes capítulos del libro puntualizan que una de las premisas dominantes en estos jóvenes países - premisa que por cierto se reflejó en la particular historiografía enhebrada por cada uno de ellos- puso énfasis en la centralidad de los grandes hombres, tesis carlyleana que coronaba al líder carismático como el ingeniero cardinal de la Historia, postulado que, por extensión, también aludió al poder determinante de las minorías ilustradas; en cambio, la población nativa y marginal habría revelado un perfil pasivo e inmutable opuesto a la dinámica del progreso. Aludiendo al tema, Funes evoca una frase del argentino Carlos Octavio Bunge: "el carácter de los hispanoamericanos es [...] la pereza, la tristeza y la arrogancia" (p. 75). Boceto similar al retrato que trazará el mexicano Samuel Ramos en la primera mitad del siglo XX, al aludir a los rasgos psicológicos de la población aborigen y mestiza de su país, presuntamente adversos al ethos de la modernidad. Argentina, Brasil, Uruguay -entre otros- estimularon, en consecuencia, "el mejoramiento de la raza" por medio de la migración de europeos; contingentes que suscitarán en el curso del tiempo actitudes desiguales: algunas pusieron énfasis en sus virtudes empresariales, pero otras en "la prostitución, la delincuencia, el anarquismo y el socialismo que trajeron a las nuevas tierras" (p. 77). Ambivalencias que también se manifestaron en la percepción de la estructura demográfica nacional, como en el caso del Brasil, que distinguió sin reservas entre un Sur pujante, empresarial y progresista, en contraste con un Nordeste atrasado $\mathrm{y}$ amorfo.

Hasta las vísperas del siglo XX, se difundieron credos políticos favorables a un Estado oligárquico y apegado a criterios raciales y clasistas, que aparejaron la consiguiente dilatación de las brechas iniciales. En este período, la democratización de instituciones y costumbres constituyó un discurso banal más que una dominante realidad.

En la segunda parte del volumen, la autora vislumbra señales de cambio. Después de un siglo de formal independencia nacional, brotaron nuevas tendencias. México, por ejemplo, pone fin al régimen porfirista y articula un sistema constitucional algo más luminoso; Argentina encara tendencias 
anarquistas que pretenden restringir los abusos del poder central; las críticas a las clases dominantes se generalizan; sus abusos e injusticias se configuran intolerables (p. 81). En Perú, Haya de la Torre moviliza a los estudiantes universitarios, actores emergentes que propiciaron el cambio social; se manifestarán en la rebelión universitaria de Córdoba, Argentina, con amplios ecos regionales. En esta coyuntura, figuras académicas y algunos intelectuales se perfilaron como mediadores entre el poder oligárquico y las masas; pero no hay lugar en este contexto para una genuina democratización: se trata de un proceso selectivo y fragmentado. El argentino José Ingenieros, por ejemplo, le adjudica a su país un indiscutible liderazgo en el espacio latinoamericano debido al predominio de la raza blanca, la fecundidad de sus tierras, el carácter templado de su clima: variables que conducirían, en su opinión, al ascenso de su país en el cuadro europeo, aspiración que Argentina concretará hasta los años treinta; desde entonces, el declive -0 sus altibajos cual helicóptero- será imparable.

Según Funes, en las décadas siguientes despuntan rasgos de un entendimiento, entre explícito y tácito, entre los gobernantes y los intelectuales sensibles al ejercicio público. La iniciativa se origina en los primeros. "Los caudillos militares revolucionarios necesitaban a los intelectuales (incluso más modestamente a los letrados) para construir y legitimar al nuevo Estado" (p. 103) . Y en este recodo vislumbraron la posibilidad de "desbarbarizar" un poder que se sustentaba en el monopolio de la violencia. La autora subraya la meritoria cruzada educativa de Vasconcelos en México, encaminada a crear símbolos de la nación mexicana, distantes de la oligarquía dominante. En términos generales, ideas como progreso, racionalidad, evolucionismo social se difundieron en América Latina, pretendiendo poner en jaque la autoridad de las élites oligárquicas. Incluso el protagonismo indispensable de los campesinos en este proyecto es invocado en los años veinte por el peruano José Carlos Mariátegui, mientras que en México, dos décadas más tarde, el presidente Cárdenas procurará asegurar la justicia con el reparto agrario y enriquecer la conciencia campesina y obrera. Estas tendencias fortalecieron posturas adversas al invasivo poder imperial de Estados Unidos, que por propio interés y en complicidad con las élites dominantes, procuraba preservar y expandir sus esferas de influencia. En respuesta, tuvo lugar el Congreso contra la Opresión Colonial en Bruselas, en 1927 (p. 107); allí se encontraron, entre los latinoamericanos, Haya de la Torre, Juan Antonio Mella, José Vasconcelos y Victorio Codovilla. Un concilio que redujo las distancias y la sensación de soledad entre los intelectuales latinoamericanos, aunque sus ecos apenas se hicieron sentir en la región. 
El ascenso de Estados Unidos como potencia mundial afectó considerablemente a las economías latinoamericanas, que no se embarcaban a la sazón en un proceso dinámico de industrialización. En esta coyuntura, las élites dirigentes debieron encarar una cultura que se expresaba en otro idioma y propiciaba un credo económico y religioso distanciados de los conocidos en la herencia española; el Destino Manifiesto es la plataforma de la incursión norteamericana en la región. Se escucha entonces la voz de José Martí, quien propala la necesidad de que "la América española" declare su segunda independencia (p. 132); José Enrique Rodó predica la rivalidad entre Ariel y Calibán: la espiritualidad latina vs. el pragmatismo sajón. El arielismo conquistó el espíritu de no pocos intelectuales: les obsequió función y presencia, casi santidad; en contraste, el capitalismo norteamericano no constituiría sólo un sistema económico: es también un paradigma ético inaceptable para los países latinos. Funes indica que "el componente antiimperialista [...] generó estrategias de poder de carácter movientista, frentista y aliancista [...] que cobraron en los años treinta y cuarenta una importancia decisiva en las formas de hacer política" (p. 145).

Esta efervescencia intelectual no condujo a resultados duraderos. En los años treinta se reiteran en América Latina tendencias francamente antiliberales. Según la autora, el fascismo italiano, el primorriverismo español, la Acción francesa, el tomismo -entre otros fenómenos- alentaron un pensamiento autoritario en la región (pp. 158 ss.). Se institucionalizó, por ejemplo, en el Estado Novo en Brasil, que abrió cauce a un nacionalismo corporativo. El Estado fue concebido como un "Leviatán benevolente que protegía a la sociedad a la vez que la corregía”. (p. 161). Los miembros de estas élites conservadoras difundieron objeciones a Lutero, Descartes y Roussseau, figuras que habrían conducido a los perversos planteamientos de Marx y Lenin. Auspiciaron además la recatolización de las masas en varios países y la modernidad se les antojó "un caos sin Dios y sin amor" (p. 163), atmósfera que condujo a regímenes autoritarios que exigieron controlar "la anarquía de las almas y la vana competencia entre partidos" (p. 168).

Sin embargo, la crisis económica de los treinta alumbró cambios en las sociedades latinoamericanas. La caída de las exportaciones, los adversos términos del intercambio, el descenso del empleo y de los salarios -entre otras variables-, obligaron la intervención activa y algo más ilustrada del Estado. Brotó la dinámica necesidad de emprender políticas de sustitución de las importaciones como ruta hacia la industrialización. Funes indica, acertadamente, que la urbanización y el crecimiento demográfico apresuraron esta 
inclinación. Sin visualizar alternativas, sindicatos y agrupaciones políticas debieron aceptar estos módulos de desarrollo económico. Al mismo tiempo, por inercia o con deliberación, no pocos países instituyeron regímenes dictatoriales e incluso incurrieron en confrontaciones bélicas (el caso de Bolivia y Paraguay). Cuando las élites no se inclinaron a favorecer un estado autoritario, las políticas populistas se perfilaron como un sustituto -en apariencia menos violento y más refinado- de los regímenes represivos. Adelgazaron las reclamaciones sociales en el corto plazo para legar deudas y crisis insalvables a futuros gobernantes; en algunos casos, líderes carismáticos sumnistraron gratificaciones circences a las masas sumidas en secular e incorregida marginalidad.

En los años sesenta y setenta, las ideas políticas latinoamericanas recogieron los ecos de la escena internacional, en particular, la revuelta estudiantil en Estados Unidos y en Europa, además de la formación de un sistema político (Cuba) claramente apoyado por uno de los actores poderosos de la Guerra Fría (la URSS). Los sucesos en La Habana se convirtieron en un punto de referencia inescapable en la definición e intercambio de ideas políticas. Funes pasa revista a los intelectuales y creaciones que surgieron a resultas de este viraje. Alarmado por los ecos de la revolución castrista, Estados Unidos y amplias fracciones de las élites latinoamericanas alentaron regímenes populistas o francamente autoritarios. En esta atmósfera, abortaron las innovadoras iniciativas emprendidas por Allende en Chile: ni el gobierno estadounidense ni élites militares latinoamericanos pudieron tolerar que prosperara un símil de Cuba en el sur de América Latina.

La constelación emergente alentó el interés en interpretaciones "estructuralistas" -y en particular las teorías de la dependencia- en torno a la condición latinoamericana, planteamientos que, en una versión moderada, ya se encontraban en los primeros discursos cepalinos. Intelectuales difundieron interpretaciones estructuralistas de la evolución latinoamericana, inspiradas en tesis marxistas y neomarxistas. Sugiero-Fuentes soslaya esta circunstanciaque no pocos de ellos expusieron estas posturas sin temores a sanciones severas por parte de los regímenes autoritarios que censuraban, pues realizaban labores en organismos regionales dependientes de las Naciones Unidas. Debidamente protegidos y bien remunerados, no asumieron dilatados riesgos al esbozar predicamentos radicales de la condición latinoamericana. El economista mexicano Juan Noyola fue un caso singular: renunció en los cincuenta a una promisoria carrera en la CEPAL para ocupar un alto cargo -con modesta compensación y los consiguientes riesgos- en Cuba. 
En estas dos décadas, los militares tomaron el poder en varios países. El designio: detener ideas "extranjerizantes", preservar la sociedad occidental y cristiana, combatir planteamientos que supuestamente pondrían en peligro la "seguridad nacional", no sólo en términos territoriales, sino ideológicos y cuasimetafísicos (p. 243). Dice la autora: "prohibido pensar en América Latina" se convirtió en esta oscura constelación, en un oficial imperativo; desobedecerlo acarreaba la clandestinidad, la emigración obligada, y, en no pocos casos, la desaparición y la muerte. Al lado de los militares defensores del "alma nacional" actuaron no pocos intelectuales, "una burocracia del mal que no vestía uniforme militar" (p. 256). Los regímenes militares no sólo asesinaron a miles de ciudadanos -en su mayoría profesionales y jóvenes estudiantes-; siguiendo el ejemplo nazi, quemaron millones de libros en estos empeños "anti-comunistas". Al final de sus indagaciones, Funes se pregunta si esta trágica evolución de las ideas políticas latinoamericanas caerá en el olvido, o si se aprenderán sus lecciones para impedir una sombría repetición de lo que fue. Considerando la apertura democrática que se perfila en algunos países desde el arranque del siglo, Funes tiende a ser optimista.

Dos defectos inquietarán al lector de este importante libro. Uno es la ausencia de notas bibliográficas, en correspondencia a los autores citados en sus páginas. Para compensar esta ausencia, Funes ofrece al final una larga lista de títulos, sin duda muy útiles para cualquier investigador y estudiante que se inclinen por ahondar en estos temas; sin embargo, apenas corrige la ausencia señalada.

Otro es el uso desbordado de argentinismos y galicismos que molestará a lectores inclinados a respetar las convenciones de la gramática española que gestan, más allá de las locuciones localistas, la existencia de una convergente escritura y lectura latinoamericanas. Algunos ejemplos: esencialismos, frentista, incumbencias disciplinarias, continentalidad, forales, denuncialista, movimientista, fundacional, aliancista, epocales, fomentalista, raciólogos, recusación, borramiento, y muchas más. Por la secuencia singular y por los cotejos que enhebra en el desenvolvimiento de las ideas políticas en América Latina, este libro es lectura obligada. Futuros acontecimientos habrán de justificar o desmentir la alentadora calidad de esta secuencia.

JOSEPH HODARA

El Colegio de México

Bar Ilan University, Israel 
Carlo Natali, Aristotle, 2013, New Jersey, Princeton University Press, 219 pp.

RECEPCIÓN: 5 de agosto de 2014.

ACEPTACIÓN: 9 de diciembre de 2014.

$\mathrm{D}$ esde hace algunos años han aparecido varias publicaciones que engarzan la biografía de los filósofos con su producción intelectual. La biografía intelectual se ha convertido en una forma de interpretación necesaria, bajo la hipótesis de la inexorable continuidad entre vida y obra. En esta línea, se encuentran trabajos como el de Rüdiger Safranski sobre Heidegger o sobre Nietzsche; el Hegel de Jacques D'Hondt; el Kant de Manfred Kuehn, o el extraordinario Philosophers' Quarrel sobre Hume y Rousseau de Robert Zaretsky. Todos ellos son una buena aproximación tanto a la obra como a la vida de los filósofos; sin duda, la "cercanía" temporal facilita la reconstrucción histórica, el acceso a las fuentes en las ediciones hoy canónicas, y la inmensa literatura que ha hecho el análisis puro y duro de cada uno de los sistemas filosóficos; sin embargo, todos estos libros se contraponen a aquello que el príncipe de los filósofos había dicho sobre la filosofía en libro segundo de la Metafisica: que trata de lo eterno. ${ }^{1}$

¿Es esto adecuado? ¿Para hablar del Ser es indispensable omitir a los entes contingentes? En todo caso, ¿será posible decir, en verdad, que los escritos filosóficos han de relacionarse necesariamente con los hechos de la biografía de los autores? Para muchos colegas hacer esto no es hacer filosofía, sino historia; todavía más, historia de la filosofía. Pero, ¿se puede entender la filosofía al margen del contexto histórico en el que se inscribe? Creo que la pregunta fundamental es si la doctrina sobre el Ser puede entenderse fuera del tiempo, sin el tiempo. Si las ideas están lo suficientemente "separadas" de la realidad

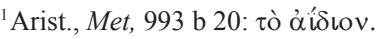


- que no abandonadas de ella-y pueden, de este modo, sobrevivir al "deslave de la historia".

Pareciera que la exigencia aristotélica y la vigencia de los textos de los grandes filósofos dan la razón al Estagirita, si tomamos en cuenta que el libro de ética más estudiado en las universidades norteamericanas en 2013 fue la Ética Nicomaquea (p. vii); sin embargo, cuando la filosofía ha pecado de abstracción y se ha alejado por completo del devenir histórico se ha hecho, al mismo tiempo, inútil aunque decorativa.

Por provocar a los lectores especializados, llamo a esta cuestión filosófica "la tensión entre lo suficiente y lo necesario": que las verdades de la filosofía, para ser eternas, deben alejarse suficientemente de la realidad, pero mantenerse adecuadamente cerca, pues podrían convertirse en abstracciones inútiles; además, deben acercarse lo suficiente, pero mantenerse prudentemente lejos, pues se corre el riesgo de convertirse en sociología. Aquí radica, en mi opinión, el encanto de la refriega filosófica que se sufre un tanto, pero se goza dos tantos más: descifrar la eternidad que se esconde detrás del momento.

Este afán de historizar los trabajos de los filósofos alcanzó también, en forma inevitable, al mismo Estagirita y a su obra; durante el siglo XX se publicaron tres estudios canónicos que, a mi juicio, son lectura obligada para cualquiera que dedique algún tiempo a enseñar a Aristóteles. El primer esfuerzo fue el de Werner Jaeger en 1923; el segundo, el de Ingëmar During, en 1959; y, finalmente, el de Carlo Natali, publicado originalmente en italiano en 1990 y traducido al inglés bajo el sello de Princeton University Press.

El libro de Natali-colega de Enrico Berti, profesor emérito de la Universidad de Padua y presidente del Instituto Internacional de Filosofía- ha tenido una extraordinaria recepción en el mundo académico; Richard Sorabji -profesor emérito del King's College en Londres, presidente de la Aristotelian Societyha dicho que prefiere este estudio al de Jaeger. Celebro la publicación de un nuevo trabajo con estas características pues, desafortunadamente, Aristóteles se ha vuelto "tan académicamente correcto" que se escucha por doquier su uso como autoridad para prácticamente todo. La famosísima cita de "el ser se dice de muchas maneras" ${ }^{2}$ ha transmutado hoy a "Aristóteles se dice de muchas maneras". Y si bien es cierto que hay diferentes interpretaciones, es más cierto que hay argumentos insostenibles a la luz del corpus y de los días en los que pensaba Aristóteles. Y esto, hoy, se está olvidando.

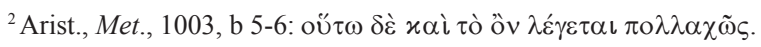


A manera de ejemplo, y sabiendo que dolerá a varios de mis colegas, Aristóteles no era un demócrata; no creía en la igualdad entre los hombres y mucho menos era un igualitarista republicano. Esto no lo hace menos canónico. El trabajo de Natali aporta, en ese sentido, una buena luz para la correcta comprensión del corpus y de los alcances filosóficos de Aristóteles.

Sobra decir que un libro de esta magnitud cuenta con un exquisito elenco de comentadores de la obra del Estagirita, tanto clásicos como contemporáneos; así, todos los que están, son, pero no todos los que son, están: extrañé referencias al trabajo de Elizabeth Anscombe y Peter Geach, Three Philosophers: Aristotle, Aquinas, Frege; o de Julia Annas, The Morality of Happiness, traducido a siete idiomas, o bien Ancient Philosophy: A Very Short Introduction; o de Sarah Broadie, Ethics with Aristotle, cuyos trabajos habrían enriquecido, sin duda, las discusiones que plantea el libro.

En la selección bibliográfica es posible detectar el prejuicio que divide a la filosofía continental de la filosofía analítica, dadas las muy pocas referencias al trabajo de autores sajones, cuando no pocos de ellos cuentan con crédito suficiente para aportar a la discusión que plantea el libro; es, quizá, la principal debilidad del texto de Natali: su continentalismo. De las 480 referencias bibliográficas que se ofrecen en el índice, solamente hay 54 textos escritos en inglés y dos en español. Es decir, el $89 \%$ de los libros que consideró Natali para su investigación fueron escritos por autores europeos. Esto llama la atención si consideramos la buena salud que gozan en estos días tanto las universidades norteamericanas como la prensa universitaria de dicho país.

A pesar de ello, Natali pone a prueba muchos de los conocimientos que han pasado de voz en voz, de manual en manual; además, nos cuenta historias insospechadas del príncipe de los filósofos. Aristóteles tuvo una vida personal mucho más interesante de lo que podríamos sospechar: fue pupilo del tirano Proxeno de Atarneo; tuvo dos mujeres: Pythia y Herpyllis; dos hijos: Nicómaco-posiblemente ilegítimo-y Pythia. No deja de ser interesante comprender la relación entre los diez miembros fundadores del Perípato; su condición de extranjero - meteco- en Atenas y su compleja relación con Estagira, su ciudad natal. Sostiene Natali: "Lo que estoy interesado en hacer aquí es reconstruir, lo mejor posible, las características históricas de esta nueva figura intelectual, y determinar sus características intelectuales" (p. 3).

El libro tiene cuatro capítulos y un postscriptum a la edición en inglés del 2013. El primer capítulo hace una interesantísima reconstrucción de la 
vida de Aristóteles, valiéndose para ello de los pocos datos que encontramos en los comentadores antiguos. La labor emprendida por Natali es cuidadosa, pues utiliza como fuentes los textos de Filodemo de Gadara, Diógenes Laercio y Cicerón, entre muchos otros; asimismo, incorpora los comentarios de los autores canónicos -Jaeger, Düring, Zeller, Gigon-y los más recientes hallazgos históricos y filológicos. De esta forma, Natali hace lo que los filólogos han llamado Quellenforschung: el estudio de las fuentes, las influencias y el trabajo literario del autor, engarzado con los pocos testimonios que tenemos de la biografía de Aristóteles. En este apartado, el lector corroborará ciertos datos que la manualística nos ha hecho llegar sobre la vida de Aristóteles; lo más interesante será, sin duda, la reconstrucción a partir de los textos de Quintilano, Dion Crisóstomo, Justino y los testimonios neoplatónicos sobre la relación entre Alejandro Magno y el Estagirita (p. 43 ss.). Así, el primer capítulo es casi delirante pues Natali engarza con maestría los rastros de la biografía y nos presenta a un Aristóteles in flesh and bones: un filósofo que escribe poemas y vende drogas durante sus años de juventud. Y esto no hace sino obligarnos a mirar de manera distinta los textos.

El segundo capítulo resultará especialmente interesante para cualquiera que se dedique a la educación universitaria, ya que en él se señalan las condiciones en las que nace el Perípato y que se traducirían en un modo de hacer filosofía que nos acompaña a la fecha. El tercer capítulo continúa con la organización interna del Perípato; al asunto de la interpretación de los textos y la enseñanza de la retórica se le otorga una dimensión distinta. A su vez, el cuarto capítulo es un exhaustivo recuento de los estudios biográficos de Aristóteles, de Zeller a nuestros días. Este esfuerzo es monumental, si consideramos que el célebre texto de Zeller, Aristotle and the Earlier Peripatetics, es de 1897. Así, en este apartado el autor da cuenta de los trabajos de Düring, Plezia, Chroust y Gigon. Natali se da a la tarea de contrastar las referencias de los comentadores antiguos con los trabajos de los contemporáneos y ofrecernos nuevas luces.

Me gustaría detenerme en el segundo capítulo, en la noción de bios theoretikos pues Natali nos ofrece, al mismo tiempo, una defensa y una reconstrucción de un cierto modo de vida que ha resultado ejemplar para la academia a lo largo de la historia y que no está de más recordar-de cuando en cuandopara no perder el foco. La actividad más noble para el hombre, sostiene Natali 
siguiendo tanto la Nicomaquea como la Eudemia, es la theoria: "Como ha demostrado T. Tracy, para la theoria, que es la actividad humana más alta, es necesario un estado de moderación y calma en el sentido psicológico; un equilibrio estable de las funciones y los deseos del cuerpo y, sobretodo, la correcta regulación de las emociones fundamentales de placer y de dolor" (p. 73).

Para lograr esto, son necesarias tres condiciones: bienes, tiempo libre para poder pensar-schole- $\mathrm{y}$ amigos. Estas consideraciones nos hacen sostener que cualquiera que quiera hacer y enseñar filosofía o dedicarse a la vida universitaria necesita condiciones económicas suficientes, tiempo para pensar y un grupo de colegas con quienes trabajar. Las universidades que han atendido estas tres condiciones son las que han llegado más lejos en la investigación; aquellas cuya labor ha trascendido los trabajos administrativos y de gestión, pues lo que la historia espera de nuestro trabajo es la producción intelectual.

Una consideración más sobre el capítulo dos: el vínculo entre la política y la academia ha sido muy cercano; lo fue en los días de Aristóteles y lo es ahora. Sin embargo, aunque haya momentos de intersección, no son lo mismo ni se confunden: el político no hace filosofía y los filósofos hacemos muy mala política. Sobran los ejemplos históricos. Es así porque la política y la filosofía persiguen fines distintos: la primera se bate con lo contingente, la segunda con lo universal; porque mientras los filósofos somos scholars los políticos son por definición $a$-scholars: "El político está naturalmente preocupado por los resultados contingentes y su condición natural es la ascholia" (p. 74).

Adelanto que el libro de Natali pone a prueba todo eso que creemos que sabemos, pero que la sofisticada reconstrucción histórica del libro nos muestra como equivocado.

\author{
VALERIA LÓPEZ VELA
}

Centro Anáhuac Sur en Derechos Humanos 
John Bailey, Crimen e impunidad. Las trampas de la inseguridad en México, 2014, México, Debate, 319 pp.

RECEPCIÓN: 25 de noviembre de 2014.

ACEPTACIÓN: 12 de diciembre de 2014.

$\mathrm{E}_{1}$

autor nos propone una manera diferente de enfocar el tema del crimen y la violencia en México. Su perspectiva se centra en las interacciones entre el crimen, violencia, corrupción e impunidad, así como la relación entre estos fenómenos con la democracia y la gobernabilidad. Se enfoca en la 'seguridad ciudadana' como un subconjunto de la noción más amplia de 'seguridad humana'. Su principal preocupación es la forma como el crimen y la violencia minan los derechos que los ciudadanos deben tener en una democracia.

Para Bailey lo importante es comprender que México está inserto en un estado de confusión, producto de una serie de factores que no solamente tienen que ver con el crimen o la relación asociativa entre crimen-empresarios-clase política.

No se puede negar que México atraviesa por un momento crítico. La debilidad del Estado y sus instituciones; la distancia entre la clase gobernante y los gobernados, que define el concepto de 'gobernanza democrática'; los intereses en los partidos políticos, que deben expresar la instancia de representación democrático-electoral; los conflictos entre la élite, que nos dicen que las cosas no están bien en absoluto. Es claro que falta un Estado de derecho creíble, equilibrado, consistente, por lo que la crisis nacional tiene muchos aspectos: por un lado, la desigualdad social y la pobreza; por su debilidad, la falta de un Estado democrático y de derecho; la inseguridad y los diversos tipos de crimen; la desconfianza entre gobernados y clase política, reflejada en la falta de credibilidad en las instituciones; y, desde luego, una erosión de los sistemas formales e informales de acceso al poder (partidos sin ideología, oportunismo en la búsqueda de los cargos, falta de relación entre el funcionario 
electo y su votantes, reglas informales de procesar candidaturas y alianzas pragmáticas entre partidos políticos con visión cortoplacista); informalidad, a-legalidad (no sentirse comprometido con la ley) e ilegalidad (violación de la ley).

La distinción entre a-legalidad e ilegalidad es interesante. Los mexicanos en general suelen sentir que la ley no se aplica en México, o en el mejor de los escenarios, solamente se aplica a los que no tienen dinero o no tienen contactos políticos ('palancas'), de modo que tienden a evadir el cumplimiento de la ley. La ilegalidad es el imperio del crimen abierto, que por grados pone en jaque al Estado y a sus instituciones.

La tesis dominante del texto es la relación entre crimen y gobernanza democrática: a mayor criminalidad, menor gobernanza democrática; por ende, un debilitamiento creciente de la capacidad del Estado para distribuir los bienes, administrar la justicia y garantizar la seguridad a cambio de la obediencia. En términos de la 'democracia', aunque los gobernados sientan el deber de ir a votar, no confían en los funcionarios electos para ejercer las funciones de gobierno; en la medida en que se debilita el Estado, se ahonda la crisis democrática y eso, a su vez, repercute en un mayor índice de criminalidad y violencia. Los países de Latinoamérica, México entre ellos, viven una trampa de seguridad: un equilibrio de bajo nivel en donde los problemas de inseguridad interactúan con instituciones judiciales y regulatorias débiles, ineficientes e incluso predatorias, que constituyen la principal causa de la baja calidad de la democracia.

Bailey distingue diferentes momentos en la política mexicana a partir de la definición de 'régimen político': “el conjunto de reglas formales e informales para el acceso al poder". Explica también que "la gobernanza democrática permite el pacto entre la sociedad y el gobierno". Ese pacto ocurre cuando la sociedad percibe que las reglas del poder benefician a la gente, por lo que el acuerdo respeta las prácticas de poder a cambio de empleo, seguridad, educación, salud y distribución de bienes. En la medida en que las instituciones son eficientes y el poder centralizado cumple con esas expectativas, el pacto se mantiene; pero si se fractura, el pacto desaparece. La ausencia de un pacto inhibe la gobernanza democrática, de modo que la élite (clase política, empresarios, altas clases medias), ejerce el poder aun a costa de la gente; esa distancia se refleja en formas de desigualdad diversas que estimulan diferentes complejos de organización criminal. 
Los tres grandes problemas que tiene México son: 1) la falta de un contrato social; 2) la desconexión del sistema electoral de partidos; y, 3) una lenta reforma del sistema de justicia penal. Bailey argumenta que una sociedad que no resuelve la criminalidad en sus diversas formas, fortaleciendo el contrato social, el sistema de justicia penal, el ataque a la corrupción y una auténtica responsabilidad de los funcionarios electos con los votantes, solamente genera fractura en la gobernanza democrática. Y viceversa: el fortalecimiento formal e informal de la democracia y sus reglas para el acceso al poder pueden fortalecer el pacto social y, con ello, disminuir la criminalidad. En América Latina los índices de correlación son claros: los países más democráticos y menos corruptos son Uruguay y Costa Rica; México apenas está por encima de Perú, Venezuela, Panamá o Guatemala.

En cuanto a lo primero, es claro que el contrato se rompe después del control centralizado y autoritario del régimen del PRI, de 1946 a 1976. Las bases de ese control contaban con el apoyo social de trabajadores, campesinos y clases medias, de suerte que había un contrato social. Se toleraba que el poder del presidente fuera absoluto, que los arreglos cupulares existieran, que no hubiese elecciones libres, que proliferara la corrupción enquistada en la clase política. El frágil Estado de derecho era permitido. La sociedad se beneficiaba: los sindicatos, por la vía de la cooptación y el clientelismo, conseguían mejoras salariales, programas de salud y mínimas condiciones de vida digna; los campesinos, a cambio de tierras o subsidios del Estado, paliaban su precaria situación; los empresarios, grandes y medianos, contaban con el apoyo de un Estado paternalista que aplicaba el modelo de industrialización por substitución de importaciones. Todo ello, que además garantizaba buenos sueldos para la clase media, propició, con base en un gasto público excesivo, que el consenso fuera amplio. Por debajo, desde el policía que admitía un soborno y el ciudadano que lo pagaba, hasta los funcionarios que se enriquecían, todos participaban de una cultura de la a-legalidad.

En cuanto a la desconexión del sistema electoral de partidos, es claro que la creciente ruptura del pacto y el contrato comenzó con la crisis que ahondó la desigualdad y el desempleo, la gran crisis de 1982. El cambio estructural y los programas de ajuste limitaron la expansión del gasto, incrementaron las tasas de interés, no detuvieron la inflación y abrieron la economía al exterior, sin protección a la industria nacional, auspiciando la creación de monopolios; como contraparte, se profundizó el desempleo y la informalidad, con sus cadenas de economía subterránea. 
Las reformas electorales y las transiciones democráticas dieron paso a un sistema de partidos cuyos dirigentes, candidatos y funcionarios más bien cuidan su 'hueso', buscan perpetuarse en puestos y ganar dinero, y se alejan de los intereses de sus votantes. Hoy, la sociedad no se identifica con el sistema de partidos. Para colmo, se incrementan los delitos de toda laya, lo que convierte la gobernanza democrática en una caricatura; en el fondo, hay evasión de impuestos, pésima recaudación fiscal, se saquea PEMEX, se depende de las remesas y el crecimiento económico es mediocre, lo que causa la paradoja: instituciones y reglas formales en las instituciones electorales, pero quienes acceden al poder por medio de esas reglas, y los gobernados, se alejan de las prácticas democráticas.

En cuanto a la reforma del sistema de justicia penal, no hace falta recordar la corrupción en los ministerios públicos y en las penitenciarías, donde lo que ocurre dentro se desconoce; las cadenas de complicidad de policías, jefes de área, funcionarios y altos mandos; los magistrados que se articulan con el crimen y el soborno (quien paga no pisa la cárcel, a menos que se trate de un 'enemigo político' o de gente pobre que pasa años tras las rejas siendo inocente). La transición a los juicios orales es lenta; los procesos y las sentencias demoran años, la gente desconfía de la justicia mexicana y del sistema en su conjunto, a pesar de tener leyes magníficas en su diseño, que no se aplican.

John Bailey sostiene que hay tres niveles de criminalidad que abarcan la sociedad mexicana en su conjunto. Lo que llama crímenes simples, complejos y de alta organización. Los primeros tienen que ver con los delitos de muchos: evasión de impuestos e informalidad; sin embargo, esa forma simple se vuelve compleja cuando se involucran redes más amplias; una vendedora informal vende refrescos en la calle, pero dentro de su 'puesto' puede vender droga al narcomenudeo y se vincula al distribuidor de mercancía pirata o de productos lícitos o ilícitos, pero de distribución ilegal (ya sea robados o clonados con etiqueta de marca y maquilados en fábricas aparentemente en regla); igualmente entran en el escenario inspectores corruptos, permisos falsos y complicidades que llegan al que maneja a varios locatarios, altos mandos policiales y funcionarios desligados de la ciudadanía. Eso causa mayor evasión y más organizaciones criminales.

En grado más elevado, se pone en jaque al Estado al entrar de lleno en delincuencia más sofisticada y generalmente violenta: narcotráfico, secuestro. Pero una cosa son dos o tres que secuestran a alguien y otra las complejas 
bandas con altos niveles de tecnología y recursos que perpetran crímenes violentos. Los tipos de criminalidad afectan de diversas maneras la vida en su tejido social:

Los crímenes contra el Estado conllevan actos cuya meta es socavar o destruir sus atributos (las fronteras nacionales, la soberanía, etcétera) o funciones (el monopolio del uso de la fuerza, la administración de justicia, etcétera). El terrorismo es un repertorio de actos cuyo propósito es erosionar o derribar al Estado; la sedición es el estímulo al levantamiento y la traición es su cometido. Los crímenes pueden orientarse a respaldar enemigos del Estado o a movilizar oposiciones violentas internas. Sus autores pueden ser un único individuo o grupos complejos y persistentes, conformados por ciudadanos nacionales, extranjeros o ambos (combinaciones transnacionales). La corrupción y la intimidación pueden ser crímenes contra el Estado cuando su blanco son las fuerzas de seguridad del Estado (las Fuerzas Armadas, la policía y la inteligencia), o sus agentes de justicia (reguladores, fiscales, tribunales y defensores públicos, entre otros) (p. 46).

Estos son los que se pueden llamar crímenes complejos de alto impacto. Están dirigidos a golpear al Estado y su intencionalidad es, precisamente, que se desgaste o desmantele la unidad del mismo; por ello, cuando el ataque al Estado proviene del terror, de la sedición, de la corrupción a altos niveles o de un ataque deliberado a los órganos de seguridad, el resultado es un tipo de crimen que pone en peligro la estabilidad misma de la soberanía nacional. Son crímenes contra la seguridad nacional, muy diferentes a los crímenes intermedios.

En un plano intermedio no se habla de crímenes que ponen en jaque al Estado como un todo:

Los crímenes de la segunda categoría — que implican graves efectos de corrupción o intimidación en funcionarios electos o designados, o en la policía, los reguladores y el poder judicial - difieren de los primeros; su objetivo no es perjudicar al régimen $\mathrm{o}$ al Estado, sino proteger o fomentar actividades informales, clandestinas o ilegales. Los intercambios simples sugieren que un único individuo, o grupos pequeños y espontáneos, sobornan o intimidan a la policía o a los reguladores. La categoría también incluye a los policías y reguladores abyectos, que extorsionan a quienes se dedican a actividades civiles y económicas, ya sean legales, informales, clandestinas o ilegales (pp. 46-7). 
Los delitos que se cometen en este nivel son propios de grupos o individuos que tienen por objeto a funcionarios, policías, burócratas o jueces. Sobornan para evitar el pago de un impuesto; dan 'mordida' para no tener que pagar multa o amagan a los cuerpos policiales en los casos de protestas, donde petardos y golpes lesionan a miembros del cuerpo policiaco; en realidad, incluso al hablar de policías abyectos muy corrompidos, tales acciones no atentan contra lo soberanía del Estado.

Tenemos, además, los crímenes que ni atacan al Estado ni tienen que ver con el soborno; son los denominados crímenes de la alegalidad. Los cometemos todos los ciudadanos en la medida en que no introyectamos el sentido de la ley; entonces, evadimos el pago de impuestos, nos pasamos los altos, no seguimos la normativa de construcción, tiramos basura, deforestamos o destruimos el mobiliario de la ciudad. En realidad, es la suma de acciones individuales que están fuera de la ley, pero que ni afectan la seguridad nacional ni tienen que ver con el soborno. Dice Bailey:

En esta categoría, lo que se tiene en mente es el desdén hacia la ley que muestran innumerables ciudadanos todos los días, en el curso de sus actividades ordinarias. Entre los efectos acumulativos se encuentran los siguientes: los gobiernos administran fondos exiguos, de manera crónica, debido a la evasión de impuestos; hay edificios que colapsan porque se han violado códigos de construcción; los bosques se esquilman sin importar las restricciones medioambientales; y el tránsito sufre embotellamientos constantes y resulta peligroso. [...] ¿De qué manera el miedo y la victimización adoptan formas políticas, ya sean positivas o negativas para la gobernanza democrática? Como se apuntó previamente, una típica línea de razonamiento es que el miedo a la victimización, en ámbitos donde la criminalidad violenta se percibe al alza, conduce a modificaciones en la actitud (medidas de autoprotección, apoyo a la restricción de los derechos civiles y a una aplicación de la ley más represiva) (pp. 98 y 47).

La relación del miedo con el comportamiento se traduce, concretamente, en medidas que la gente adopta para protegerse; también repercute en la demanda social de que haya represión o mano dura para frenar la inseguridad, lo que lesiona la democracia. Y desde luego, la gente puede pensar que es mejor suspender garantías o que se cancelen ciertos derechos a cambio de paz y orden, lo cual vulnera formas de convivencia democrática.

Para Bailey las bandas del crimen organizado ligadas a las drogas dependen de los mercados, las instituciones y las oportunidades. Durante el 
gobierno del presidente Calderón (2006-2012), se fragmentaron las organizaciones, al granularlas con el objeto de analizar sus mecanismos funcionales: cómo operan, producen y distribuyen, hasta que se llega a identificar cuáles son las grandes organizaciones, la interacción entre ellas y cómo se vinculan con el sistema político. El resultado conocido es que dicha fragmentación no resolvió el problema de la violencia; la disputa por territorios, efecto de esa granulación, acarreó asesinatos entre grupos y la confrontación con el Estado.

Hay tres tipos de cárteles: los llamados alfas, que están en la cima de todo el negocio, con armas, recursos, empresas, lavado de dinero, cadenas de producción, articulaciones trasnacionales; son los Cárteles de Sinaloa, los Zetas y el Cártel del Golfo. Tienen redes, corrompen y evaden el castigo con facilidad. Los betas (Tijuana, Juárez, La Familia, Los Caballeros Templarios), se arman mejor, pues actúan a nivel local y regional; son muchos grupos intermedios que rigen en territorios específicos. Y los gamma (Guerreros Unidos en Morelos, JaliscoNueva generación, los Charros en el sureste y muchas células en todo el territorio), que distribuyen en puestos, en la calle, en tiendas, llegan a barrios y zonas pequeñas de corte urbano. Evaden, corrompen y frecuentemente enfrentan a las policías a balazos.

¿Qué se necesita? Bailey expone los puntos del Plan Colombia, sugiriendo que el gobierno mexicano los tome en cuenta; si se sigue cabalmente, es posible que se reduzcan los niveles de criminalidad, violencia y, por ende, que se fortalezca la gobernanza democrática.

Planeación en términos estratégicos con respecto a prioridades y secuencias. La utilización de un plan piloto de acción integral, antes de aumentar la escala a mayores esfuerzos. Mejoras en la coordinación interinstitucional, tanto entre las fuerzas armadas como entre éstas y la policía. La creación de un ministerio de defensa, bajo un liderazgo civil, para coordinar mejor a la policía y las fuerzas armadas. La creación de una fiscalía nacional independiente. La profesionalización y el fortalecimiento de la Policía Nacional [...] Entrenamiento especializado y organización de unidades de las fuerzas armadas y criminales. Mejoras significativas en la inteligencia y la movilidad (p. 255).

Por supuesto, se requiere atacar organizaciones intermedias y simples, reformar el sistema de justicia y tener una gendarmería nacional. Si lo vemos con cuidado, eso es lo que de alguna manera está intentando hacer el gobierno 
del presidente Peña Nieto. Crimen e impunidad. Las trampas de la inseguridad en México es un libro intenso, inteligente. Hay que leerlo. Aporta datos escalofriantes que dejan poca esperanza. No es muy preciso en propuestas, pero deja claro que el crimen en México debilita la gobernanza democrática, erosiona las instituciones, desalienta la participación política, empaña el pacto social y daña la economía. El autor nos debe un análisis más minucioso en torno al concepto de Estado fallido; dice algunas cosas obvias, como que es menester combatir la corrupción, limpiar de abajo hacia arriba y que se reforme el Estado, pero hasta ahí.

JOSÉ MANUEL OROZCO GARIBAY

Departamento Académico de Estudios Generales Instituto Tecnológico Autónomo de México 